Andrews University

Digital Commons @ Andrews University

\title{
A Strategy for Strengthening Romanian Seventh-day Adventist Families Dealing with Couple Separation due to Economic Reasons
}

Mihail Baciu

Andrews University

Follow this and additional works at: https://digitalcommons.andrews.edu/dmin

Part of the Practical Theology Commons

\section{Recommended Citation}

Baciu, Mihail, "A Strategy for Strengthening Romanian Seventh-day Adventist Families Dealing with Couple Separation due to Economic Reasons" (2006). Professional Dissertations DMin. 696.

https://dx.doi.org/10.32597/dmin/696

https://digitalcommons.andrews.edu/dmin/696

This Project Report is brought to you for free and open access by the Graduate Research at Digital Commons @ Andrews University. It has been accepted for inclusion in Professional Dissertations DMin by an authorized administrator of Digital Commons @ Andrews University. For more information, please contact repository@andrews.edu. 


\section{ABSTRACT}

\section{A STRATEGY FOR STRENGTHENING ROMANIAN SEVENTH DAY ADVENTIST FAMILIES DEALING WITH COUPLE SEPARATION DUE TO ECONOMIC \\ REASONS}

by

Mihail Baciu

Adviser: Dr. Marciana Popescu 


\title{
ABSTRACT OF GRADUATE STUDENT RESEARCH
}

\author{
Dissertation
}

Andrews University

Seventh-day Adventist Theological Seminary

Title: A Strategy For Strengthening Romanian Seventh-day Adventist Families Dealing With Couple Separation Due To Economic Reasons

Name of researcher: Mihail Baciu

Name and degree of faculty adviser: Marciana Popescu, Ph.D.

Date completed: July 2006

\section{Problem}

Financial challenges in Romania have prompted many Seventh-day Adventist people to leave their spouses and country to seek employment abroad. The impact of this phenomenon upon families has been significant. This situation occurred primarily between 1991 and 2000. Before 1990, generally speaking, the number of Seventh-day Adventist family separations or divorces was very low (around 30-40 families) in Romania. After 1991, this number increased dramatically to estimated 10-12,000 families. Temporary separation of spouses for economic reasons does not necessarily lead to a divorce. However, due to the complex implications of temporary separation on families, children and faith communities, this problem needs immediate attention.

This study aimed to identify factors leading to separation, direct implications for the family, as well as existing support systems for couples undergoing temporary 
separation. The ultimate purpose of the study is to further inform program development to strengthen Seventh - day Adventist families in post-Communist Romania.

\section{Method}

The project reviewed current literature, including books and articles about factors that affect the family, and methods and strategies that address negative factors impacting the family. As part of this research, we also created a database of actual circumstances of Adventist Romanian families, through the collection of information from the Romanian Union Conference and from local Romanian Seventh-day Adventist churches most affected by this phenomenon.

First, a survey was used to gather information about families affected by partial migration. Second, the focus group method was implemented to debate this problem at the level of the Romania Conference and Union.

\section{Results}

The goal of this project was to improve relationships within Romanian Seventhday Adventist families by strengthening the relationship between spouses and between parents and children. Concurrently, an anticipated effect of the implementation of this project is a decrease in the number of divorces among Romanian Seventh-day Adventist families.

\section{Conclusion}

A church is strong if the families that compose that church are strong. We expect that the findings of this study will be used to implement an effective strategy that will contribute to the strengthening of families in the SDA Church in Romania. This project 
can also be implemented in other countries confronted with similar, limited term emigration problems. 
Andrews University

Seventh-day Adventist Theological Seminary

\title{
A STRATEGY FOR STRENGTHENING ROMANIAN SEVENTH DAY ADVENTIST FAMILIES DEALING WITH COUPLE SEPARATION DUE TO ECONOMIC REASONS
}

\author{
A Dissertation \\ Presented in Partial Fulfillment \\ of the Requirements for the Degree \\ Doctor of Ministry
}

by

Mihail Baciu

July 2006 


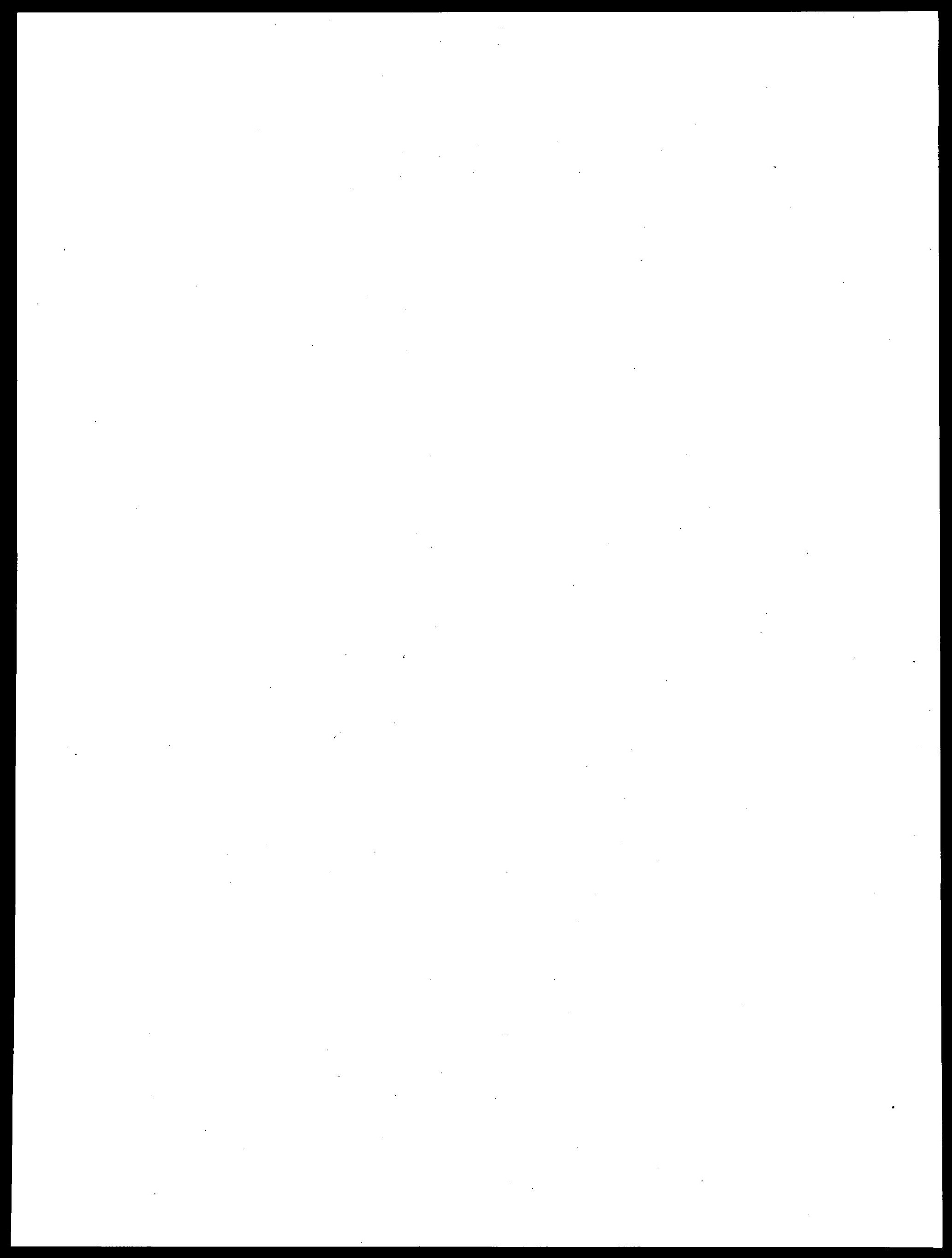




\title{
A STRATEGY FOR STRENGTHENING ROMANIAN SEVENTH DAY ADVENTIST FAMILIES DEALING WITH COUPLE SEPARATION DUE TO ECONOMIC REASONS
}

\author{
A dissertation \\ presented in partial fulfillment \\ of the requirements for the degree \\ Doctor of Ministry
}

by

Mihail Baciu

APPROVAL BY THE COMMITTEE:

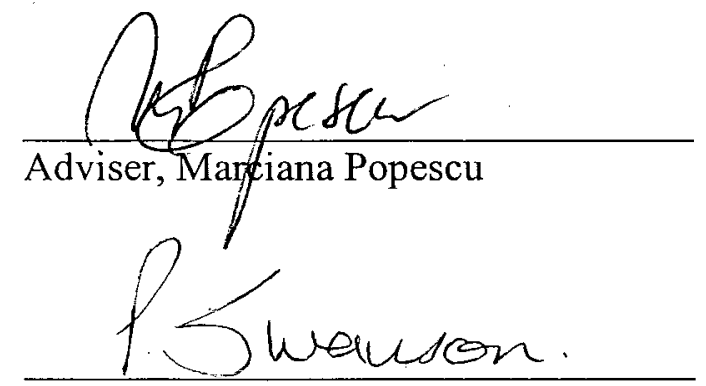

Peter Swanson

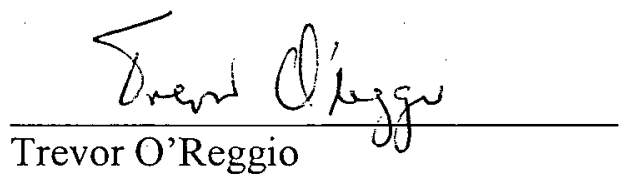

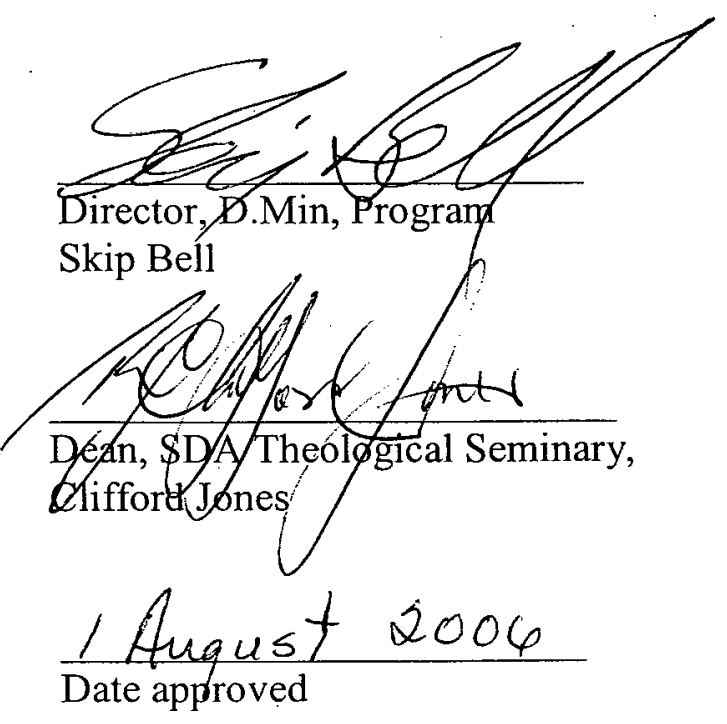




\section{TABLE OF CONTENTS}

LIST OF FIGURES AND TABLES $\ldots \ldots \ldots \ldots \ldots \ldots \ldots \ldots \ldots \ldots \ldots$

ACKNOWLEDGMENTS $\ldots \ldots \ldots \ldots \ldots \ldots \ldots \ldots \ldots \ldots \ldots \ldots \ldots$ vii

\section{Chapter}

1. INTRODUCTION ............................

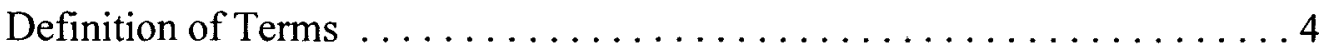

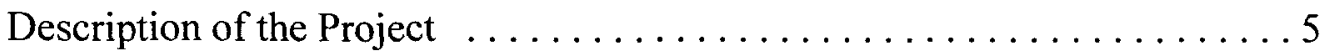

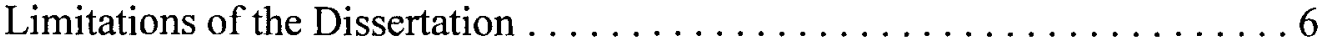

2. BIBLICAL FOUNDATION FOR FAMILY UNITY $\ldots \ldots \ldots \ldots \ldots \ldots \ldots \ldots$

Authority, Power Structures, and Family Dynamics in the Bible . . . . . . . .9

Multiple Marital Relationships: Polygamy in the Bible .......... 15

Changes and Challenges to the Patriarchal Family Model . . . . . . . . 17

God's Intention for Marriage and the Family . . . . . . . . . . . . 18

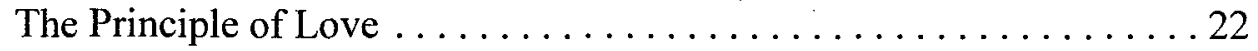

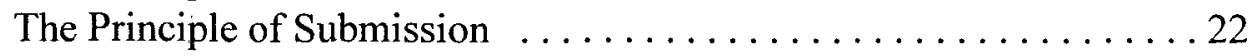

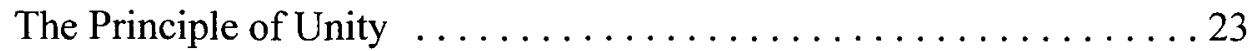

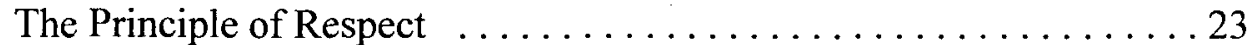

Bible Families: Lessons Learned . . . . . . . . . . . . . . . . . . . . 24

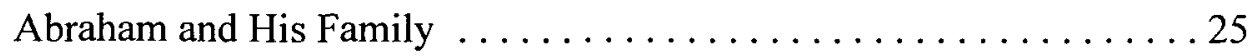

Ruth and Naomi ... . . . . . . . . . . . . . . . . . . . . . 27

King David's Family .................... 28

The Ideal for Family Life Reflected by Ellen White's Writings . . . . . . . 30

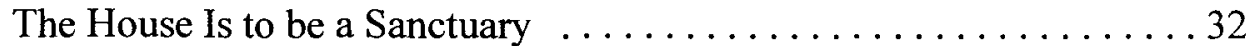

The Family as a Light of the World . . . . . . . . . . . . 32

The Family as the Primary Institution Educating the Children

for the Kingdom of Heaven $\ldots \ldots \ldots \ldots \ldots \ldots \ldots$

The Family as a Reflection and Model of Divine Love . . . . . . . . 35

3. HISTORICAL OVERVIEW OF ROMANIAN FAMILY LIFE $\ldots \ldots \ldots \ldots . . .37$ 
Separation for Employment Purpose-Social Problems Confronting

Seventh-day Adventist Families after 1989 . . . . . . . . . . . . . 37

A Historical Overview of Family Structures in Romania Prior to 1989 . . . 39

Fall of the Communist Regime and Its Impact on Family Life . . . . . 48

The Post-Communist Crisis-Social, Economic, Political, and

Cultural Factors Influencing Family Life $\ldots \ldots \ldots \ldots \ldots . \ldots 51$

The Distribution of Roles in the Romanian Family ........... 55

Family Functions in the Context of Separation for Economic Reasons . 60

The Economic Function . . . . . . . . . . . . . . . . . . 60

The Socialization Function ....................6 60

Current Problems Faced by Romanian Couples ..........61 61

4. EMIGRATION AND CONSEQUENCES OF EMIGRATION ON

INDIVIDUALS, FAMILIES, AND COMMUNITIES $\ldots \ldots \ldots \ldots \ldots \ldots 65$

Introduction ..................................65

Emigration Patterns in Romania before 1989 . . . . . . . . . . . 67

Reasons for Emigration . .......................... 71

Emigration from Romania, after 1989 . . . . . . . . . . . . . . . . . 73

Consequences of Partial Emigration on Individuals and Families . . . . . . . 77

Positive Consequences ......................... 77

Immediate Economic Improvement . . . . . . . . . . . . 77

Accumulation of Wealth and Status . . . . . . . . . . . . . . 77

Improved Work Ethics ........................ 78

Negative Consequences ........................ 78

Marital and Family Problems Due to Temporary Separation .... 78

Lack of Emotional Support . . . . . . . . . . . . . . . . . . . 79

Consequences of Emigration on Community . . . . . . . . . . . . 79

Increased Standards of Living through Improvement of Local

Infrastructure .............................. 79

Leadership Development . . . . . . . . . . . . . . . . . . . . 79

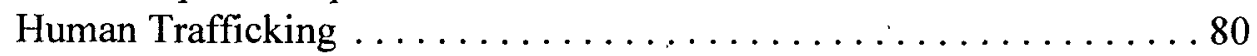

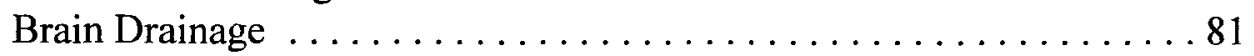

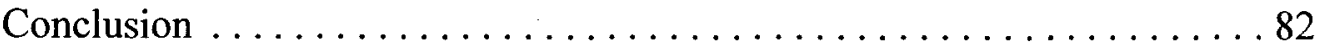

5. METHODOLOGY AND FINDINGS $\ldots \ldots \ldots \ldots \ldots \ldots \ldots \ldots \ldots$

Methodology ................................... 84

Characteristics of the Survey $\ldots \ldots \ldots \ldots \ldots \ldots \ldots \ldots$. . . . . . . . 85

Findings ..................................... 87

Perspectives on Temporary Family Separation $\ldots \ldots \ldots \ldots \ldots . . .67$

Church's Response to Temporary Family Separation .......... 91 
Community's Response to Temporary Family Separation . . . . . . . . 96

Perspectives on Potential Solutions to Problems ................ 99

Perspectives of Pastors and Leaders of the Church . . . . . . . . . 101

Ideal Versus Reality within the Christian Family ........... 101

Current Problems for the Christian Family and Methods of

Addressing These Problems ................... 101

Separation As a Solution or As an Aggravating Factor . ...... 102

The Role of the Church in Assisting the Family with Problems . 103

The Role of the Pastor . . . . . . . . . . . . . . . . . . . 103

Potential Solutions in the Church and Community . . . . . . . . 104

The Attitude of the Church Regarding Separation .......... 104

Discussion on Findings . . . . . . . . . . . . . . . . . . . 105

Conclusion

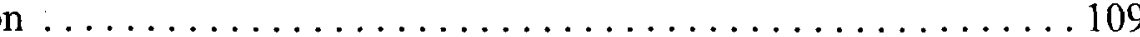

6. STRENGTHENING FAMILY: CHRISTIAN APPROACHES TO FAMILY ISSUES ASSOCIATED WITH TEMPORARY SEPARATION . . . . . . . 111

Practical Steps in Strengthening Families: A Christian Approach . . . ... 114

Conclusion ................................... 120

7. A STRATEGY TO STRENGTHENING ROMANIAN SDA FAMILIES: RECOMMENDATIONS AND CONCLUSIONS $\ldots \ldots \ldots \ldots \ldots \ldots \ldots 121$

Recommendations for Individuals . . . . . . . . . . . . . . . . . . . 124

Recommendations for the Church and Pastor ............... 125

Intervention ............................... 128

Recommendations for the Union Conference $\ldots \ldots \ldots \ldots \ldots \ldots \ldots . \ldots 130$

Services Outside of the Church . . . . . . . . . . . . . . . . . . . . . 131

Appendix

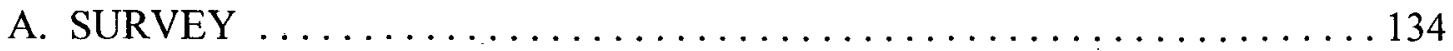

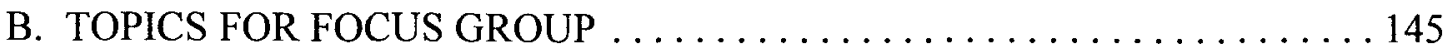

C. ROMANIAN ADVENTISTS' EMIGRATION FOR WORK-AN APPEAL

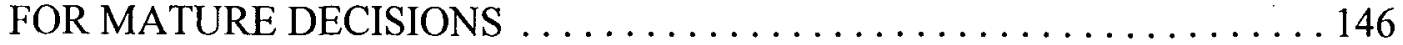

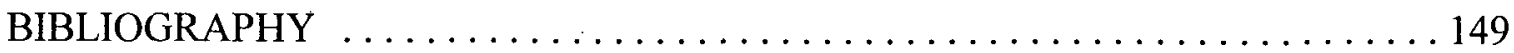

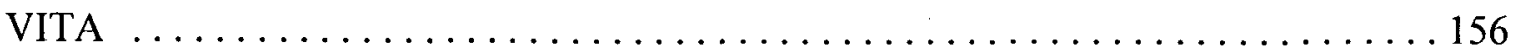




\section{LIST OF FIGURES}

Figures

1. Romanian employment abroad 49

2. The number of workers legally sent abroad .50

3. Top reasons for separation. .88

4. Acceptable reasons for short-term separation. 89

5. Experience of family separation. .90

6. Consequences of couple separation on the family .91

7. Views on separation in the faith community .93

8. Support provided by relatives .94

9. Support provided by the church .95

10. Support provided by neighbors 97

11. Support provided by friends. 97

12. Current Responses to Separation. 99

\section{LIST OF TABLES}

Table 1. Romanian Online Survey. .75

Table 2. Families Affected by Separation 86 


\section{ACKNOWLEDGMENTS}

My first thanks are for God who assisted and gave me His precious grace and help. Also, I am sure that this project would not have been possible without the support of many people. Many thanks to my advisor, Dr. Marciana Popescu and Dr. Peter Swanson, who read my numerous revisions and helped, make some sense of the confusion. Thanks also to Dr. Skip Bell, the director of this program. Thanks to Dr. Trevor O'Reggio, the third reader, and Rita Pusey, the secretary of the Doctor of Ministry office. It wouldn't be fair to forget Mrs. Linda Bauer, my editor for her great job. And finally, many thanks to my wife, Viorica and my daughters Ada and Eva, and numerous friends who endured this long process with me, always offering support and love. 


\section{CHAPTER I}

\section{INTRODUCTION}

\section{Project Goals}

The goals of this project are:

1. To evaluate the impact of separation due to distant employment on the Seventh-day Adventist family unit

2. To identify the factors that negatively affect the family in which one spouse is temporarily absent, and

3. To devise methods to strengthen Seventh-day Adventist families undergoing temporary separation for economic reasons

\section{Justification for the Project}

Family has always played an important role in the life of a society. It is a medium in which characters are formed, children are raised and educated, and cultural and civilization values are transmitted from generation to generation. Of course every generation has been confronted with specific problems and situations. However, today we are witnessing new and unprecedented realities and situation, which lead to a stress and tension in the family. More and more voices declare that family, instead of being a blessing for humanity, is a cause of conflict and a barrier in the way of freedom and real happiness. 
Modern society identifies solutions for many of life's problems. Electronic and technological advancement provides individuals with increased leisure time. Unfortunately, the solutions for problems that confront families remain elusive. "The church has not been called to simply marry people, but to establish Christian homes."1

The Seventh-day Adventist family in Romania is confronted not only with role conflicts, family violence, high divorces rates, and juvenile delinquency, but also with poverty and financial stress. Due to a low economic standard of living, Romanian parents are unable to cover the costs of a good education for their children. They cannot provide a good and healthy lifestyle for their families. Many conflicts, which may lead to family violence, stem from a lack of money.

"Unfortunately, government and community services are more remedial than preventive. Like physicians, they wait until families are in serious trouble before they offer "intervention."” Observing and recording family problems is not enough. The church is called by God to minister not only to the families in trouble, but also to address those factors that negatively affect the happiness in the family.

The collapse of the communist regime in Eastern Europe brought about economic, social, cultural and political changes, and posed challenges that were at times beyond the capabilities of the new democratic government. In terms of religious freedom, the year 1989 became the dawn of evangelism and active Christian mission in countries where atheism was previously the sole ideology. Existing churches, if still functional, became

\footnotetext{
${ }^{1}$ Willie Richardson, Reclaiming the Urban Family (Grand Rapids, MI: Zondervan Publishing House), 18.

${ }^{2}$ Charles M. Sell, Family Ministry (Grand Rapids, MI: Zondervan Publishing House), 20.
} 
part of an orchestrated political strategy promoting control and powerful domination of the masses.

The Romanian Seventh-day Adventist Church is directly affected by the new definitions of freedom that vary according to values that are new to members of the church. These newly embraced values include the active expression of freedom of speech, freedom of thought, and freedom of movement in an increasingly globalized world. These dramatic changes open old frontiers for new explorers from the East. An outgrowth of Romania's dramatic changes over the past ten years is an increase in migration of Romanian citizens to Western countries. This migration is triggered by the need for economic survival in a country with high inflation rates and a very weak market economy. A significant proportion of married individuals in Romania decide to temporarily separate from their families in order to seek higher wages in Western countries. This trend is reflected in similar proportions among Romanian Seventh-day Adventist families.

Like the general public, pastors face the problem of family separation, and must cope with the loss of a spouse who leaves the country, church, and family in order to provide familial economic support. The spouse who remains in Romania must contend with increasingly demanding and stressful responsibilities as a single parent, as well as with the curious eye of the church as it observes the married couple's separation.

Before 1990, the number of separations and divorces among Romanian SDA couples was insignificant (20-30 families). After 1991, however, the number of separations for employment purposes increased dramatically (10-12,000 families). 
Moreover, this figure does not take into account the number of unreported separations that may result in divorces in the near future.

Where both partners agree that one spouse will emigrate for economic reasons, the marital relationship is not as adversely affected. Instead, the challenges of separation are overcome by strong spiritual connections and by strong commitments between the parties.

Identifying and understanding the strengths of families who remain healthy and functional despite separation and hardship, is an important research objective, as these families will become a resource for families going through similar situations, and yet struggle to maintain emotional and spiritual health.

The Family Life Department of the Romanian Union encouraged this project by providing information that may be used to create a strategy for the benefit of families confronted with the problem of separation. This project will be implemented at the local church, Conference, and Romanian Union level.

\section{Definition of Terms}

Family Life Department—a special department within the General Conference of the Seventh-day Adventists that promotes Christian life in the family through programs and seminars. ${ }^{1}$

Post Communist crisis-a period of time after 1989 when communism was abolished, and when Romania was confronted with the depreciation of national currency

'General Conference of Seventh-day Adventist, Seventh day Adventist Church Manual (Hagerstown, MD: Review and Herald, 1995), 114-115. 
and with an economic crash that lead to a lowered standard of living. At the same time, the family was seriously confronted with financial and relational problems.

Temporary separation between spouses - a limited time (six months to four years) when one spouse, with the agreement of the entire family, seeks employment abroad as a means of providing economic support for his or her family.

\section{Description of the Project}

A review of current literature, will serve to inform a strategy to address negative factors impacting the family.

A study of biblical and theological literature is presented in order to discover the Christian foundation for the family unity. This study will focus on God's original plan for the family. A strategy to meet the needs of twenty-first century families by. strengthening the unity and love between spouses, and between parents and children, will be developed.

We will analyze data provided by 600 surveys completed by members of the Romanian church, who are confronted with the problem of spousal separation. The main purpose of this survey is to obtain information about reasons, negative and positive experiences resulting from spousal separation, and the consequences of the spousal separation.

Recommendations for families confronted with crises and for churches assisting families confronted with such crises will be presented. 


\section{Limitations of the Dissertation}

The first area of limitation involves the literature used. While there is enough literature on the topic of emigration and on other family issues resulting from separation of spouses, very little has been written on this subject from a Christian perspective. Therefore, we were limited in providing a thorough Christian background to the topic.

The second area of limitation is in the somewhat narrow application of this project. The primary purpose of this project is to assist Romanian Seventh-day Adventist families who face the crisis of separation due to economic hardship. In order to extend the area of application to non-Adventists too, it should take into consideration many more factors. Nevertheless, this project may also be used to strengthen other Adventists or non-Adventists families confronted with the problem of separation, and those who come in contact with the Seventh-day Adventist Church. 


\section{CHAPTER II}

\section{BIBLICAL FOUNDATION FOR FAMILY UNITY}

\section{General Concept}

In order to understand the role of the family in the context of human relationships, it is necessary to study the time when God created the world. After He finished all His creation, God created the first man and made him the king of this earth. "God created man in his own image, in the image of God he created him; male and female he created them" (Gen 1:27). ' It was God's purpose when He created Eve to give to Adam a proper helper and a collaborator in his duty as caretaker of this earth.

In the most wonderful place on earth, adorned with a natural garment, God gave humanity two precious gifts: a home and a family. Through these institutions, God intended to offer fulfillment, happiness, and relationships to human beings. It was His plan to multiply them and to spread them throughout the world. For this reason, God gave them a special blessing when He said, "Be fruitful and increase in number, fill the earth and subdue it. Rule over the fish of the sea and the birds of the air, and over every living creature that moves on the ground" (Gen 1:28).

God is the originator of the family. The family was established by God in His inaugural act of the marriage between a man and a woman. The Bible further defines the

\section{Version.}

'Unless otherwise stated, all Bible references are from the New International 
family through God's instruction for married couples to have children. "God blessed them and said to them, "Be fruitful and increase in number.... Adam lay with his wife Eve, and she became pregnant and gave birth to Cain. She said, "With the help of the Lord I have brought forth a man" (Gen 1:28; 4:1). Seventh-day Adventists believe that the purpose of the family is to glorify and honor God by forming a spiritual, emotional, physical, and economic foundation for individuals, the church, and society.

It is at home that children see manhood and womanhood modeled. It is at home that moral values are taught by parents and placed into the hearts of their children. It is at home that people see the reality of a relationship with Jesus Christ modeled. It is at home that people learn to live out their convictions. Therefore, Seventh-day Adventists are committed to upholding the concept of family as God's original and primary means of producing godly offspring, and passing on godly values from generation to generation (Eph 3:14-15; Gen 1:26-28; Rom 8:15, 23; John 1:12; Gal 3:29; Ps 78:5-7; Deut 6:4-9).

Ellen White, one of the most prolific authors in the Seventh-day Adventist Church states, "The Lord was pleased with this last and noblest of all His creatures, and designed that he should be a perfect inhabitant of a perfect world. But it was not His purpose that the man should be alone."1

Little information about early family life exists because our early ancestors did not leave a written account of family structure. The Bible reports reveal something about the structure and the role of family in ancient times.

The Hebrew nation, one of the oldest peoples on earth, began its existence in approximately 2000 B.C., when, "responding to a divine command, he (Abraham) began

'Ellen G. White, The Adventist Home (Washington DC: Review and Herald Publishing Association, 1980), 25. 
a journey with his tribe which took him initially from Ur to Haran."1 Because this people were chosen by God to be His people in order to fulfill His plan, God promised that, "I will keep you and will make you to be a covenant for the people and a light for the Gentiles" (Isa 42:6). For that reason, the Bible focuses on the history and the life of the Hebrew nation.

\section{Authority, Power Structures, and Family Dynamics in the Bible}

The society in the ancient Israel is characterized by a strong sense of family values that have the central point in the relationship between the members of the family. When we talk about Jewish families we have to accept the idea of different senses and meanings.

1. First of all, the term "family" could strictly refer to the nuclear family formed by parents and unmarried children. "In the days when the judges ruled, there was a famine in the land, and a man from Bethlehem in Judah, together with his wife and two sons, went to live for a while in the country of Moab" (Ruth 1:1).

2. Another meaning could be referring to the extended family. Beside the circle of parents and unmarried children, there are married children and their spouses, eventually their children. "The LORD then said to Noah, 'Go into the ark, you and your whole family, because I have found you righteous in this generation"' (Gen 7:1). This is a clear reference to the extended Noah's family because, "Noah and his sons and his wife

${ }^{1}$ Holman Bible Dictionary, ed. Trent C. Butler et al. (Nashville, TN: Holman Bible Publisher, 1991), s.v. "Polygamy." 
and his sons' wives entered the ark to escape the waters of the flood" (v. 7).

3. "Family" could be also referring to a whole tribe. "Abraham will surely become a great and powerful nation, and all nations on earth will be blessed through him. For I have chosen him, so that he will direct his children and his household after him to keep the way of the LORD by doing what is right and just" (Gen 18:18-19).

4. Sometimes Bible refers to the people Israel as a "family," or "house," "Hear what the LORD says to you, O house of Israel" (Jer 10:1).

Within a group of individuals, there are rules and roles maintained by a structure of power that is assumed and respected by its members. Every society exercises power and authority according to its culture and tradition. In the biblical times even though the family values placed the family in the center of society, some "contend that Hebrew Scripture does not stress the cultural centrality of the family. For example, Charles and Carrie Thwin (1948) argued, that being highly patriarchal, the Semitic family traditionally has made the father rather than the family itself the basic cultural unit, and this emphasis is evidenced in the ancient Semitic practice of poligyny and subordination of woman."1

The patriarchal model of the authority is defined by Ignatius Hunt (1967), as an organization of society and government where the authority of fathers is exercised over

\footnotetext{
'Jay Newman, Biblical Religion and Family Values: A Problem in the Philosophy of Culture (Westport, CT: Praeger/Greenwood Publishing Group, 1948), 37.
} 
their children and husbands over their wives. ${ }^{1}$ In the context of patriarchal culture it is hard to believe that women played another role except to give birth and raise children. Because "the ultimate, decisive authority in the family was that of the father," ${ }^{2}$ he took the most important decisions and all members of his family had to follow his determinations. In order to maintain men's authority, "women were educated differently from men and were restricted to studies that did not permit them to challenge masculine authority." 3

Summarizing what was presented so far, according to the Bible as well as other theological and historical writings ${ }^{4}$, the authority in the ancient Hebrew family was endowed in the oldest man of the house. Usually the father was not only the head of the household invested with power of decision but also the priest of the family having the role of spiritual leader, instructing his family in the fear of the Lord, and performing the ceremony of sacrifices. At the same time the patriarch had limits in exercising the authority and "he was not entirely free to rule in an arbitrary manner." Abraham was maybe the best example of "head of the family" invested by God with authority and power. God knew in advance about his faithfulness, and that he "will direct his children

${ }^{1}$ Ignatius Hunt, The World of the Patriarchs (Englewood Cliffs, NJ: Prentice-Hall, 1967), 55.

${ }^{2}$ John Marshal Holt, The Patriarchs of Israel (Nashville, TN: Vanderbilt University Press, 1964), 106.

${ }^{3}$ Margaret J. M. Ezel, The Patriarch's Wife Literary Evidence and the History of the Family (Chapel Hill \& London: The University of North Carolina Press, 1987), 8.

${ }^{4}$ Norman Linzer, The Jewish Family: Authority and Tradition in Modern Perspectives (New York: Human Science Press, 1984).

${ }^{5}$ Stuart A. Queen, Robert W. Habenstein, John B. Adams, The Family in Various Culturse (Chicago: J.B. Lippincott, 1961), 151. 
and his household after him to keep the way of the LORD" (Gen 18:19). Ellen G. White speaks about the authority that Abraham exercised upon his family. "He [Abraham] was the priest of his home. He looked upon his family as a sacred trust. His household numbered more than a thousand souls, and he directed them all, parents and children, to the divine Sovereign. He suffered no parental oppression on the one hand or filial disobedience on the other. By the combined influence of love and justice, he ruled his household in the fear of God, and the Lord bore witness to his faithfulness."1

God created the first couple, Adam and Eve, with equal rights and the same obligations to love each other and submit to the Lord. "The wife is neither the slave nor the property of her husband, but his consort and companion."

After the fall in sin, the issue of authority in relationship between them was a necessity. Different controversial topics, their different opinions could create an endless fight with unpredictable consequences. "So if a sense of order is to be maintained, family members must be guided by overarching principles of conduct. Without rules, family conversation can erupt into angry arguments that produce hard feelings and broken fellowship."

For this reason God stated immediately after fall, "To the woman he said, 'I will greatly increase your pains in childbearing; with pain you will give birth to children. Your desire will be for your husband, and he will rule over you"' (Gen 3:16). Instead of being a source of perpetual fight for supremacy, the principle of submission was designed

\footnotetext{
'Ellen White, Conflict and Courage, 49.

${ }^{2}$ John A. Ryan, Family, http://www.newadvent.org/cathen/ 05782a.htm (July 11, 2006).

${ }^{3}$ Craig S. Kinner, Virtue Illustrated by the Christian Family (London, England: InterVarsity Press, 1994), 1.
} 
to be a blessing. Unfortunately, many so-called Christians justify their abusive conduct in relationship with their wives citing from the apostle Paul, "Wives, submit to your husbands as to the Lord" (Eph 5:22). Does the apostle Paul encourage the domestic abuse in this passage? Does he want to say that the principle of submission is limitless? To understand this passage this way is to pervert the principle of submission and the role of the Gospel in our life. In a Christian family the principle of submission is not limited to the relationship between husband and wife, but it goes to the relationship between husband and Christ, too. When a husband, having the authority of his family, is submitted to Christ the same way Christ is submitted to God, his wife will submit to him voluntarily.

Therefore, the role of the Gospel is to bring family to the same state where it was before fall: "There is neither Jew nor Greek, slave nor free, male nor female, for you are all one in Christ Jesus" (Gal 3:28).

Family being a divine institution created by God in Paradise, it is very important to understand the Bible's point of view regarding the authority issue. The apostle Paul several times pictured the family life in parallel with church life. Just an example is enough to understand his opinion. "For the husband is the head of the wife as Christ is the head of the church, his body, of which he is the Savior. Now as the church submits to Christ, so also wives should submit to their husbands in everything" (Eph 5:23-24).

This scriptural passage, as many others, brings to our attention the principle of submission as a model of authority. The Divinity offers us an example of perfect submission and authority at the same time. The Father, the Son and the Holy Spirit are one: the same substance, the same nature, the same character. God, the Father's role of 
authority is visible from the first to the last page of the Scripture. The same model of authority God offered to the first couple He created in the Garden of Eden.

It is not easy for us, in our culture, to understand this model of authority due to the perversion from the original plan. "Submission" in the secular context is translated as inferior or of lesser importance. God did not create Eve as a slave for Adam or less valuable than him. Only sin perverted the sense of submission. When man exercises authority in a dictatorial way and ask and receive submission out of fear from his wife, this is a perversion of God's original plan.

We witness the same misinterpretation of the principle of submission in the modern society, and even more, in conservative Christian subcultures. In the Romanian SDA church, the influence of the Communist ideology coupled with a misinterpretation of submission in the family. While on one hand, the Communism promoted equality between genders, on the other hand it created a totalitarian regime, based on power hierarchies. In the same way, while promoting brethren in Christ, the SDA church established power hierarchies, replicating the patriarchal model, with an emphasis on power and authority. At different levels-Union, Conference, and District-the president or the pastor demanded supreme authority and every complaint or contradiction or argument between a member of the church and pastor or a pastor and the president of the conference or union was considered an offence against God and His Church.

As it could be expected, the same duality and misinterpretation of submission is at play in the Adventist families, in establishing power dynamics between spouses. Ultimately, the male authority was promoted by the church, having therefore its support 
even when abusive or dysfunctional. The author of this dissertation was a pastor in a big church where the physical correction was always directed to the "disobedient" wife.

\section{Multiple Marital Relationships: Polygamy in the Bible}

As already mentioned above, during the Patriarchal period absolute power was given to the "head of family," the father. The father alone made family decisions. A man's wives were considered to be his property. Hebrew men from the upper class were permitted to have more wives and concubines. King Solomon is a striking example of this practice: "He had seven hundred wives of royal birth and three hundred concubines, and his wives led him astray" (1 Kgs 11:3). "One rationalization for this polygamy-a man having more than one wife-was the high value placed on sons. A barren wife (one unable to bear children) might even give her female servant to her husband as a concubine and claim the children as her own."'

Thus, the practice of maintaining multiple relationships exists not only among individuals who did not know God or who had lost their spiritual way, but it also existed among people who received special blessings from God. "I will bless those who bless you and whoever curses you I will curse; and all people on earth will be blessed through you" (Gen 16:1-2).

From a modern perspective, it is easy to understand family problems that arose in biblical times. The Bible records expound upon the nature of problems arising when God's plan for the family was disregarded, and provide examples that may be applied to modern circumstances.

'Dianne Hales, The Family (New York: Chelsea House Publisher, 1988), 24. 
Such an example may be found among God's Hebrew people. "There was a certain man from Ramathaim, a Zuphite from the hill country of Ephraim whose name was Elkahanah. ... He had two wives; one was called Hannah and the other Peninnah. Peninnah had children, but Hannah had none" (1 Sam 1:1-2). Even though in ancient times (still in some modern cultures) God permitted polygamy and blessed richly the family (see Abraham, Jacob, Elkanah), the ideal of the family institution is the unity between one man and one woman. It is difficult to accept the idea of polygamy and to understand how God could allow His original plan to be disregarded. Love cannot be divided. God did not create man to share his love with more than one wife. When another wife arrives, when the husband must share his love with two, three, or one thousand wives, love loses it brightness and uniqueness. Multiple wives lead to a break down of the marital relationship in a single step. The relationship among family members "can break down at a variety of levels from a variety of causes. These causes include decreased liking for the partner, reduced satisfaction with the partner relative to another potential partner, unsatisfactory performance by the partner of role obligations, sexual problems, difference in desired intimacy, and dissatisfaction with the relative reward and costs of maintaining the relationship."

In Elkanah's family, the problem was: (a) two wives (different from the original plan of God), and (b) lack of children born to the most loved wife, Hannah. Elkanah could not equally divide his love between his two wives, "but to Hannah he gave a double portion because he loved her" (1 Sam 1:5).

'Gregory R. Pierce, ed., Handbook of Social Support and the Family (New York: Plenum Press, 1996), 176. 
Although God never authorized polygamy, He showed compassion toward sinful human beings. God accepted, for a time, the human weakness of polygamy in order to ultimately lead His people to His original plan. It is interesting to observe how God balances the scale in the biblical account of Elkanah and his family: "And the Lord had closed her [Hannah's] womb" (v.5). At that time, children were considered a blessing. Conversely, a lack of children was considered a curse. God blessed Penninah with children and "closed her [Hannah's] womb" in order to give Elkannah the opportunity to balance the cup of his feelings between Hannah, his childless wife and Penninah, the mother of his children.

When God created "the heavens and the earth" (Gen 1:1), and when God said: "Let us make man in our image, in our likeness" (Gen 2:26), His original plan was for man to marry one wife. God did not create polygamy; it arose as a result of man's alienation from God.

\section{Changes and Challenges to the Patriarchal Family Model}

Among the factors that lead to present challenges to the patriarchal family model we can mention the loss of power for religious authorities and the emergence of a secular society; the emancipation of women; and the joining of the workforce by women.

Starting with the French Revolution (1789) when revolutionaries considered family a part of institution of aristocracy, we assist to a declining authoritative role of the father in family. The French Revolution led to a debate over roles and authority, eventually stressing equality as a ruling principle in guiding both institutional and family affairs. The principle of submission is questioned, and we witness the rise of modern feminism with the emancipation of women. "The first women's rights convention is held 
in Seneca Falls, New York. After 2 days of discussion and debate, 68 women and 32 men sign a Declaration of Sentiments, which outlines grievances and sets the agenda for the women's rights movement. A set of 12 resolutions is adopted calling for equal treatment of women and men under the law and voting rights for women."1

Equal rights lead to equal expectations. However, it is only during the last half of the twentieth century that we witness a massive joining of the workforce by women as a necessity but also as another attempt to challenge tradition family roles and demand equality and autonomy. "The entry of married women into the labor force, so that they acquire a money income independent of their husband."

Due to the changes in our society, the traditional roles and expectations in the family are challenged. We can argue both ways, seeing clear benefits in a more egalitarian family model, but also witnessing the many problems that modern families are facing. In the midst of these changes, there is a rise of materialism, as the need for more is often considered the precondition for better. Ironically, the reality demonstrates that today's family has more comfort, a higher level of education, more money, but more troubles than ever.

\section{God's Intention for Marriage and the Family}

God's divine plan for family relationships is clearly revealed in the Bible. The following examples demonstrate God's divine model of family life.

\footnotetext{
${ }^{1}$ Ann Marie Imbornoni, Women's Rights Movement in the U.S., http://www.infoplease.com/spot/womenstimeline1.html\#WHM-1800, (July 11, 2006).

${ }^{2}$ John N. Edwards, ed. The Family \& Change (New York, NY: Alfred A. Knopf, 1969), 252; see also J. M. Mogey, A Century of Declining Parental Authority.
} 
A. After their creation, God gave a special blessing to Adam and Eve, sanctifying their unity and their life, saying: "Be fruitful and increase in number, fill the earth and subdue it. Rule over the fish of the sea and the birds of the air" (Gen 1:28).

The human family was extremely important to God. He blessed the first couple and gave them the solemn charge to increase in number and to take care of the earth. Since the inception of creation, the Bible identifies two institutions that God blessed: the family and the Sabbath. Both are sacred, and both were created in order that man could obtain complete satisfaction with his partner (family) and with his Creator (Sabbath). Because God is the Creator of the family, He is concerned about its well-being, offering support, encouragement, and advice to those who ask Him. Moreover, He offers help even before the wedding according to the next point.

B. God is willing to answer the prayer of those who ask advice in choosing a partner for life.

In Gen 24, Abraham sent his servant to find a bride for his son. According to the culture and custom of that time, the parents chose a bride for their son or a groom for their daughter. Abraham's servant did not begin his journey until he first sought wisdom and special guidance from God to assist him in this important mission.

The servant's prayer reveals his faith in God and his need of divine guidance. Clearly, Abraham's servant realized that his mission was an extraordinary one. "Then he prayed: 'O Lord, God of my master Abraham, give me success today, and show kindness to my master Abraham" (Gen 24:12). The servant asked for a sign from God, and God gave him the answer he desired. 
Abraham's servant recognized the importance of seeking God's guidance in the selection of a spouse. Abraham's son, Isaac, also recognized the importance of special spiritual preparation for his wedding: "He went out to the field one evening to meditate" (Gen 24:63).

The Bible states that: "Isaac brought her into the tent of his mother Sarah, and he married Rebekah. So she became his wife, and he loved her; and Isaac was comforted after his mother's death" (Gen 24:67).

We are tempted to think that people from biblical times were not confronted with the same problems like ours such as starvation, poverty, or loneness. The next point will reveal a God of all generations involved in the family's needs.

C. In a time of crisis, God provides for family needs. Gen 37-44 records a fascinating story about Jacob's family, one of the most conflicted families in the Bible, and the problems they confronted.

The theme of family separation stemming from economic hardship is illustrated in the account of Jacob and his family. In order to provide for their families, Jacob's sons decided to leave their homes and separate from their spouses and children for economic reasons for a limited time, and travel to Egypt to obtain provisions of food for their families.

At the outset of this story, Jacob's sons and their families faced the serious threat of starvation. For this reason, Jacob called his sons together and devised a plan to rescue his extended family. "When Jacob learned that there was grain in Egypt, he said to his sons, 'Why do you just keep looking at each other?' He continued, 'I have heard that there is grain in Egypt. Go down there and buy some for us, so that we may live and not 
die"" (Gen 42:1-2). "The famine extended to the land of Canaan and was severely felt in that part of the country where Jacob dwelt.",

The journey likely took them a couple of weeks. Ellen White, speaking about the distance between Canaan and Egypt, states, "Eleven days after leaving Mount Horeb the Hebrew host encamped at Kadesh, in the wilderness of Paran, which was not far from the borders of the Promised Land"2 Jacob's sons were separated from their families throughout this period.

God created the family to live together and to stay together; to sustain, to encourage, and to resist temptation together. Unfortunately, because of sin, and due to some financial difficulties, reality may be different.

Not every plan of providing nourishment for the family has a chance of success. Sometimes because of the lack of wisdom, at other times due to the misunderstanding of God's plan for their life or other reasons, people do mistakes. What does God do in these situations?

D. God does not abandon people when they make mistakes, but is involved in the resolution of family problems. The story of Elkanah, Hannah, and Peninah provides a biblical account of a family confronted not only with daily problems, but with rivalry and hate. "The blessing so earnestly sought by every Hebrew was denied this godly pair; their home was not gladdened by the voice of childhood; and the desire to perpetuate his name led the husband — as it had led many others - to contract a second marriage. But this step, prompted by a lack of faith in God, did not bring happiness. Sons and daughters

'Ellen G. White, Patriarchs and Prophets (Boise ID: Pacific Press Publishing Association, 1989), 224.

${ }^{2}$ Ellen G. White, Patriarchs and Prophets, 387. 
were added to the household; but the joy and beauty of God's sacred institution had been marred and the peace of the family was broken."

As the preceding biblical examples illustrate, generations of families were confronted with economic, relational, and life and death problems. A genuine family is not without problems, but one where every member understands his or her responsibilities, and tries to help the others to survive, to increase happiness, and to develop a deep level of communication that is the basis of a good relationship.

The principles given by God define family values. The Bible provides a thorough description of these principles for family values.

The Principle of Love

"Husbands, love your wives, just as Christ loved the church and gave Himself up for her" (Eph 5:25). The principle of love is the strongest link in a relationship between the members of the family, because love is the root of God's relationship with us.

Ellen G. White writes that not only must husbards love their wives, but also that such love must be reciprocal. "Marriage, a union for life, is a symbol of the union between Christ and His church. The spirit that Christ manifests toward the church is the spirit that husband and wife are to manifest toward each other."2

The Principle of Submission

"Submit to one another out of reverence for Christ" (Eph 5:21).

${ }^{1}$ Ellen G. White, Patriarchs and Prophets, 569.

${ }^{2}$ Ellen G. White, The Signs of the Times, November 11, 1903, 3. 
In the Asian culture, where women had limited rights and where the men were "the head," the apostle Paul wrote: "Submit to one another" God did not create Eve to be an inferior help for Adam. God did not intend for a woman to be a slave for her husband.

"Eve was created from a rib taken from the side of Adam, signifying that she was not to control him as the head, not to be trampled under his feet as an inferior, but to stand by his side as an equal, to be loved and protected by him."1

\section{The Principle of Unity}

"For this reason a man will leave his father and mother and be united with his wife, and the two will become one flesh" (Eph 5:31). In this verse, the apostle Paul quoted God's statement when He blessed the first couple in Eden.

\section{The Principle of Respect}

"Husbands, in the same way be considerate as you live with your wives, and treat them with respect as the weaker partner and as heirs with you of the gracious gift of life, so that nothing will hinder your prayers" (1 Pet 3:7).

More than exhibiting a good behavior toward his wife, Peter emphasizes the importance of the husband using his "superior strength and experience in her behalf, and thus honoring her by becoming her protector and support."2 "Husband and wife are to be faithful to each other so long as life shall last, ever revealing the self-sacrifice that leads to the truest happiness and the highest perfection of character. The husband is to be the

'Ellen G. White, The Adventist Home, 25.

${ }^{2}$ Adam Clarke, Commentary on the Bible (Chicago, IL: World Bible Publishing, 1997), 1286. 
house band of the family, the priest of his home. The wife is to respect and love her husband, and he is to love and cherish his wife. ${ }^{1}$

\section{Bible Families: Lessons Learned}

The Bible is candid in its portrayal of family life during ancient times, including its accounts of familial problems, joys and sorrows, and happiness and troubles. It is unknown whether the families of 5,000-6,000 years ago had more or less problems than the families of the present generation, but the problems they faced are likely similar to those faced today. In some cases the loss of one spouse generated poverty and lack of protection. "The wife of a man from the company of the prophets cried out to Elisha, "Your servant my husband is dead, and you know that he revered the Lord. But now his creditor is coming to take my two boys as his slaves" ( $2 \mathrm{Kgs} 4: 1)$.

Illicit love is a source of stress and lack of comfort today; it was the same in the biblical days. "But he refused to listen to her, and since he was stronger than she, he raped her. Then Amnon hated her with intense hatred. In fact, he hated her more than he had loved her. Amnon said to her, "Get up and get out!"(2 Sam 13:14-15).

God gave His followers solemn and high responsibilities in order to spread the faith in Jehovah throughout the world. Through their example of faithfulness and happiness, families facing challenges were intended to be a light in the darkness of false worship.

The Bible provides several examples of families who remained faithful to God.

'Ellen G. White, Manuscript Release, vol. 18 (Silver Spring, MD: Ellen G. White Estate, 1993), 121. 
Abraham and His Family

"The Lord had said to Abram, 'Leave your country, your people and your father's household and go to the land I will show you"' (Gen 12:1). Because God called Abraham he was ready to leave Ur, his home. Ur, "a prominent Sumerian city,"l was one of the most civilized cities of its time. Archaeological discoveries reveal that the city of Ur was highly civilized. Ur's residents practiced the arts of reading, writing, and counting. Homes in Ur had two levels, and an elaborate sewer system that extended throughout the city. Abraham's experience illustrates an early example of people who left their home and their country to travel abroad, in order to experience a new life. Although Abraham's primary objective was not to improve his family's economic condition, he nevertheless provides an example of faithfulness and love for his family.

Abraham and his wife, Sarah, faced a crisis when Abraham expected God to fulfill His promise to give him a son, but fulfillment of the promise seemed to be delayed. In order to "help" God to fulfill His promise, Abraham listened to Sarah, and according to the custom of that time had a sexual relationship with her maidservant, Hagar. Following this act of faithlessness, Abraham had a son who was not the son of God's promise, but who was the son of his own will. "God had called Abraham to be the father of the faithful, and his life was to stand as an example of faith to succeeding generations. But his faith had not been perfect. He had shown distrust of God in concealing the fact that Sarah was his wife, and again in his marriage with Hagar."

'Holman Bible Dictionary, ed. Trent C. Butler et al. Nashville, TN: Holman Bible Publisher, 1991), s.v. "Ur." 1970), 56.

${ }^{2}$ Ellen G. White, Conflict and Courage (Washington DC: Review and Herald, 
Abraham's personal plan for the future of his family generated considerable pain within his home. Hagar's attitude of pride and superiority and Sarah's spirit of jealousy and humility brought accusations, fights, and general discord into Abraham's house. The consequences of his mistake did not end at the time of Abraham's death. An attitude of hatred and a desire for supremacy continues to exist between descendants of Ishmael and Isaac.

The consequences of his own marriage with Hagar, and of the marriage connections of Ishmael and Lot, were before him. The lack of faith on the part of Abraham and Sarah had resulted in the birth of Ishmael, the mingling of the righteous seed with the ungodly. The father's influence upon his son was counteracted by that of the mother's idolatrous kindred and by Ishmael's connection with heathen wives. ${ }^{1}$

Polygamy had become so widespread that it had ceased to be regarded as a sin, but it was no less a violation of the law of God, and was fatal to the sacredness and peace of the family relation. Abraham's marriage with Hagar resulted in evil, not only to his own household, but also to future generations. ${ }^{2}$

In spite of all these problems that have confronted Abraham's family, God's plan was fulfilled for him and his family. Abraham was called "the man of the altars" because he understood the mission that God gave to him. Wherever Abraham encamped with his family on the journey to Canaan, he erected an altar for Jehovah, calling all his family to join with him in worship. The account of Abraham and his family provides an example of proper worship to the true God.

He would instruct his family in righteousness. The law of God would be the rule in his household. Abraham's household comprised more than a thousand souls. Those who were led by his teachings to worship the one God, found a home in his encampment; and here, as in a school, they received such instruction as would prepare them to be representatives of the true faith. Thus a great responsibility rested

'Ibid. 57.

${ }^{2}$ Ellen G White, The Daughters of God (Hagerstown, MD: Review and Herald 1998), 27. 
upon him. He was training heads of families, and his methods of government would be carried out in the households over which they should preside. ${ }^{\text {' }}$

Through a good spiritual orientation and through proper worship of Him, God planned that the family be a light in the night.

\section{Ruth and Naomi}

"In the days when the judges ruled, there was a famine in the land, and a man from Bethlehem in Judah, together with his wife and two sons, went to live for a while in the country of Moab" (Ruth 1:1). This biblical story, which contains many sensitive moments, presents an illustration of a family confronted with serious hardships. The primary reason the man and his family left their home in Bethlehem was a lack of food and a difficulty in sustaining the family through the time of famine. Migration to a new country, familial separation for economic reasons, and relocation in a new community is not the best solution for a family. At times, however, circumstances require parents to make difficult decisions in order to avoid starvation and the collapse of the family.

It was not easy and painless for "a man from Bethlehem in Judah, together with his wife" to make the decision to move with both their sons to the country of Moab, which was a Canaanite country. The inhabitants adored their national god, Chamos, and also worshipped his consort, Ashtar.

Naomi realized that Moab was not an ideal place to raise children due to the idolatrous environment, but she and her husband made their decision to relocate based upon material considerations rather than spiritual ones. Moab offered the family

'Ellen G. White, Patriarchs and Prophets, 141. 
salvation from starvation, but one can imagine that they suffered from spiritual hunger because the Temple of Jehovah, the center of their worship and manifested presence of God, was far away.

Naomi was confronted with the devastating loss of her husband and both of her sons. Following their deaths, she was completely alone in a foreign land. Far from her blood relatives and from her religious community, Naomi was forced to face the tragic reality of separation that confronts many immigrants today.

Like others experiencing the loss of loved ones, Naomi believed that God fought against her and punished her for her sins. "Don't call me Naomi," she told others, "Call me Mara, because the Almighty has made my life very bitter. I went away full, but the Lord has brought me back empty. Why call me Naomi? The Lord has afflicted me; the Almighty has brought misfortune upon me" (Ruth 1:20-21).

Many individuals, when confronted with separation from the family, follow a pattern of thought that is similar to Naomi's; they place the responsibility for their troubles on God. Such discouragement is common at times when grief overflows the heart, and when an individual is not psychologically prepared to battle discouragement.

Families offer strong pillars of mental, physical, and emotional support to individual members. Familial separation removes these important pillars from an individual's life, and may result in harmful or fatal consequences.

\section{King David's Family}

Although God called David "a man after his own heart" (1 Sam 13:14), and although David promoted religious and spiritual values within his own family, he was not 
exempt from trouble and conflicts. David's sin with Bathsheba generated a long succession of conflicts within his family, and resulted in the death of four of his children.

In a time when the Israelite nation was expecting stability and peace, David by his unfaithful act of self-indulgence demonstrated a lack of respect for the values of the family that could keep him out of many troubles.

David's homesickness and love for his family is demonstrated at a time when he was forced to stay away from his home and family. "David left Gath and escaped to the cave of Adullam. When his brothers and his father's household heard about it, they went down to him there" (1 Sam 22:1). "In the cave of Adullam the family were united in sympathy and affection. The son of Jesse could make melody with voice and harp as he sang, "Behold, how good and how pleasant it is for brethren to dwell together in unity!" (Ps 133:1).

David's care for his parents is revealed in his request to the king of Moab: "From there David went to Mizpah in Moab and said to the king of Moab, "Would you let my father and mother come and stay with you until I learn what God will do for me?" (1 Sam 22:3).

God's plan for the family is to be together and to be united. Although problems may disturb Christian family members for a time, such problems are ultimately overcome by the desire among family members to be together, to be harmonious, and to share their feelings with one another. "Our great need is unity. We have not one soul that can be

\footnotetext{
${ }^{1}$ Ellen G White, Patriarchs and Prophets, 658.
} 
spared. The Lord calls upon us to unify in harmony with Bible truth. This should be repeated over and over in the family and in the church."1

We cannot ignore the fact that the God's plan for family can be accomplished when parents and children understand their role in bringing the family to the moral standards presented in the Bible. One of the Ten Commandments specifies the relationship between children and parents: "Honor your father and your mother, so that you may live long in the land the Lord your God is giving you" (Exod 20:12).

Not only religious, but also secular literature speaks about the relationship between children and aging parents. "Family scholars often seem to forget that families have old members. Traditional definitions of family describe the nuclear family as composed of two parents (male and female) and dependent children."2

In the New Testament, God's plan for the family remains the same as set forth in the Old Testament. The original plan was not changed by sin. Although humanity missed God's goal, He still has the same purpose as at the time of creation.

\section{The Ideal for Family Life Reflected by Ellen White's Writings}

Ellen G. White was a woman of remarkable spiritual gifts who lived during the nineteenth century (1827-1915). "Seventh-day Adventists believe that Mrs. White was more than a gifted writer; they believe she was appointed by God as a special messenger

\section{${ }^{1}$ Ellen G. White, Manuscript Releases, vol. XXI, (Silver Spring, MD: Ellen G.} White Estate, 1993), 463.

${ }^{2}$ Victoria H. Bedford and Rosemary Blieszner, "Older Adults and Their Families," in Handbook of Family Diversity, eds. David H. Demo, Katherine R. Allen, Mark A. Fine (New York: Oxford University Press, 2000), 218. 
to draw the world's attention to the Holy Scriptures and help prepare people for Christ's second advent."

Ellen G. White's writings reflect her preoccupation with the spiritual life as it affects all areas of Christianity. As a mother and wife, she manifested a keen interest in the topic of family. She believed that a love relationship with God and with others must be cultivated. Moreover, she asserted, both parents have the duty "to cooperate with God by bringing their children up in His love and fear. They cannot displease Him more than by neglecting to train their children aright.",

The following pages will present the ideal for family life as set forth in Ellen White's writings.

The Family: An Agent for the Blessing and Uplifting of Humanity "The grace of Christ, and this alone, can make this institution what God designed it should be - an agent for the blessing and uplifting of humanity. And thus the families of earth, in their unity and peace and love, may represent the family of heaven." ${ }^{3}$

There is a need for Christian families to reveal Christ to others. Families of the present generation have lost many of God's blessings as a result of deviation from God's original plan. God's plan for the family today remains as it was in Eden: the family on earth is to represent the family in heaven.

${ }^{1}$ Arthur L. White, Ellen G. White: A Brief Biography (Silver Spring, MD: Ellen G. White Estate, 2000), 1.

${ }^{2}$ Ellen White, Adventist Home, 268.

${ }^{3}$ Ellen G. White, God's Amazing Grace (Washington DC: Review and Herald 1973), 115. 
The House Is to be a Sanctuary

God intends that the home be a sanctuary, where worship is practiced and all members of the family have fellowship with each other. "The house is the sanctuary for the family, and the closet or the grove the most retired place for individual worship; but the church is the sanctuary for the congregation."

When the Sabbath begins, it is a special privilege for the family to honor God by their worship.

"Before the setting of the sun let the members of the family assemble to read God's word, to sing and pray. There is need of reform here, for many have been remiss. We need to confess to God and to one another. We should begin anew to make special arrangements that every member of the family may be prepared to honor the day, which God has blessed and sanctified."2

The Sabbath creates the opportunity to worship God weekly, and it is the family's privilege to bring the God's holy presence within the home daily.

The Family as a Light of the World

"The mission of the home extends beyond its own members. The Christian home is to be an object lesson, illustrating the excellence of the true principles of life. Such an illustration will be a power for good in the world. ... As the youth go out from such a $2000), 189$.

'Ellen G. White, The Faith I Live By (Hagerstown, MD: Review and Herald,

${ }^{2}$ Ellen G. White, Testimonies for the Church, vol. 6 (Mountain View, CA: Pacific Press, 1928), 356. 
home, the lessons they have learned are imparted. Nobler principles of life are introduced into other households, and an uplifting influence works in the community."

A Christian family is a missionary agent for preaching the gospel by words and by example; it sets forth the strongest sermon that could be preached. Ellen White emphasizes this principle when she writes, "One well-ordered, well-disciplined family tells more in behalf of Christianity than all the sermons that can be preached. Such a family gives evidence that the parents have been successful in following God's directions, and that their children will serve Him in the church.",

Ellen White notes that, "He who lives Christianity in the home will be a bright and shining light everywhere." 3 Abraham and his family were chosen by God to be a ray of light in the darkness of the Canaanites. Similarly, families from this generation are called to provide a spiritual light in the midst of darkness. Happiness within a family provides its members with physical, mental, and emotional blessings. Every Christian family member holds a responsibility to be a light for God, and to share Christian happiness and love with others.

\section{The Family as the Primary Institution Educating \\ Children for the Kingdom of Heaven}

One of the most wonderful blessings that God gave to Adam and Eve in the Garden of Eden was the ability to bear children. Solomon recognized this precious gift

\footnotetext{
'Ellen G. White, Ministry of Healing (Boise, ID: Pacific Press, 1988), 352.

${ }^{2}$ Ellen White, The Adventist Home, 32.

${ }^{3}$ Ibid., 39.
} 
when he wrote, "Sons are a heritage from the Lord, children a reward from him" ( $\mathrm{Ps}_{\mathrm{s}}$ 127:3).

More important than the responsibility to bear and nurture children is the responsibility to educate them in the fear of the Lord, and to prepare them for the Kingdom of Heaven. Nothing is more important for children than to acquaint them with the Word of God through language and by personal example.

Ellen White makes very clear the responsibilities of the parents for their children and the consequences of their endeavors. "The early training of children is a subject that all should carefully study. We need to make the education of our children a business; for their salvation depends largely upon the education given them in childhood. Parents and guardians must themselves maintain purity of heart and life, if they desire their children to be pure. As fathers and mothers, we should train and discipline ourselves. Then as teachers in the home, we can train our children, preparing them for the immortal inheritance."

Jay E. Adams presents an interesting idea about God's blessing of children. He says, "God lends children to parents for a while to prepare them for the future; then off they must go."2

Ellen White places the parents' duty of proper Christian character development in children above the importance of houses, businesses, and material endeavors. "Here is your work, parents, to develop the characters of your children in harmony with the

'Ellen G. White, "Training Children for God," Advent Review and Sabbath Herald, September 8, 1904, 3.

${ }^{2}$ Jay E. Adams, Christian Living in the Home (Philipsburg, NJ: Presbyterian and Reformed Publishing Company, 1972), 54. 
precepts of the Word of God. This work should come first, for eternal interests are here involved. The character building of your children is of more importance than the cultivation of your farms, more essential than the building of houses to live in, or of prosecuting any manner of business or trade."

God gave parents a special responsibility to help their children to discover the value of a personal relationship with Christ. Home is the place where the ideal for children is fulfilled.

The Family as a Reflection and Model of Divine Love

Genuine relationships in the family are based on love, sympathy, and tenderness. "The home that is beautified by love, sympathy, and tenderness is a place that angels love to visit and where God is glorified. The influence of a carefully guarded Christian home in the years of childhood and youth is the surest safeguard against the corruptions of the world. In the atmosphere of such a home the children will learn to love both their earthly parents and their heavenly Father."2

Ellen White emphasizes the idea of warm relationships developed through love, kindness, and gentleness in the home. She places a warm relationship above money and material things. "Leave your business cares and perplexities and annoyances when you leave your business. Come to your family with a cheerful countenance, with sympathy, 169.

'Ellen G. White, Child Guidance (Washington, DC: Review and Herald, 1982),

${ }^{2}$ Ellen G. White, Mind, Character and Personality (Nashville, TN: Southern Publishing Association, 1977), 216. 
tenderness, and love. This will be better than expending money for medicines, or physicians for your wife. It will be health to the body and strength to the soul."1

"Let patience, gratitude, and love keep the heart though the day may be ever so cloudy."2

Not only living together, or sharing the financial and material responsibilities, or looking for the self-satisfaction, but also united by commitment and love, self sacrifice and harmony this is God's plan for the family, even living in a fallen nature.

A successful and lasting marriage is neither a result of hazard, nor a present you discover among the wedding's gifts. It is the consequence of offering and accepting support within the circle of the family. If "materialism is toxic for happiness," spirituality and love are the main components of real happiness. Not what you have makes you happy, but what you are.

'Ellen G. White, Testimonies for the Church, vol. 1 (Mountain View, CA: Pacific Press Publishing Association, 1948), 695.

${ }^{2}$ Ellen G. White, Ministry of Healing (Mountain View, CA: Pacific Press Publishing Ȧssociation, 1909), 393.

${ }^{3}$ Marilyn Elias, "Psychologists Now Know What Makes People Happy," in USA Today, December 10, 2002, http://www.biopsychiatry.com/happiness (July 9, 2006). 


\section{CHAPTER III}

\section{HISTORICAL OVERVIEW OF ROMANIAN FAMILY LIFE}

\section{Separation for Employment Purpose—Social Problems Confronting Seventh-day Adventist Families after 1989}

In order to have a general view of the whole picture, we have to consider the family in relationship to other social institutions such as the school, the church, and the community.

The family represents the nucleus of society and forms a bridge between an individual and the society. The individuals who live and sustain the family have a natural biological, psychological, and moral relationship with each other and are responsible to the society in which they live. ${ }^{1}$

In Romania, the traditional family often consists of individuals from two or three generations who live in the same house or in the same area, and who transmit values and customs to the young. The role of the family is to produce offspring, obtain the goods necessary for survival, socialize the children, transmit social values, and integrate family members into social life.

Traditionally, the wedding of young couples was arranged by parents, who were involved not only in material preparation for the wedding ceremony, but also in choosing

\footnotetext{
${ }^{1}$ Steven Lewis, The ABC's of Real Family Values (Harmonswordswoth,
} Middlesex, England: Penguin Books, 1998), xii. 
the life partner for their son or daughter. The fortune of the parents had to be divided according to the number of their children. Traditionally, every child used to receive his part immediately and not at the death of his parents. Rich families used to have just one child and in this case the whole fortune remained intact.

In accordance with tradition, the priest as a representative of the church had a strong influence in the family. Because the church performed every important ceremony in the community (the baptism, wedding, and the funeral) it had a special impact upon the family. By promoting Christian values the church also discouraged infidelity and divorce, and openly condemned the use of contraceptive methods for family planning. All these practices of daily life were enforced by interdictions and moral rules.

The Romanian traditional family and its impact upon the community were analyzed by different sociologists who presented in their writings or films, everyday Romanian village life and the countrymen's concern about family, community, traditions and costumes.

One of them, Dimitrie Gusti, produced a series of documentaries: "Dragu, a Day in a Certain Romanian Village" (1929), "Coirnova Village" (1931), "Sont Commune" (1935), and "The Romanian Village Museum" (1936), as a cinematographic report. Among his findings, he noticed: "During my research and as a result of these scientific experiences, I always encountered different and varied forms of social reality, all of which were parts of the whole representing a unified multiplicity that we called 'social unity,' a term which received a special value. . . Social unity is a present end and a beginning to come; a product of the past, and the medium and a producer of the future, a 
closed system of social values today and an open system for the values which will be created."1

According to Dimitrie Gusti, characteristics of the village community are described as follows:

1. The relationship between the family and the local community is represented by the authorities - the official persons having a special function and role in the life of the community such as the priest, the teacher, the mayor, or the doctor. The authority of such officials was recognized because of their higher levels of education, and because of their involvement in the primary social events of the village (including death, health education, school education, etc.).

2. The solidarity of the community group is generated by the daily activity of the village, the predominant activity being agriculture.

3. Due to his involvement in activities that gave him authority and influence as a wage-earner or as the traditional head of the family, the husband held a more important role in the family.

4. Important decisions were made by men or approved by them.

\section{A Historical Overview of Family Structures in Romania Prior to 1989}

Due to the degradation of social and political life in Romania after the Second World War, social studies as a discipline decreased in interest. In 1948, by ordinance of Communist Party, sociology was abolished. All classes at the university or college level were canceled. After a long struggle, and also due in part to the political position of

\footnotetext{
${ }^{1}$ Dimitrie Gusti, Opere, vol. 1 (Bucharest, Romania: Academy Publishing House, 1958), 353.
} 
Miron Constantinescu, sociology was reactivated in 1966 at the University of Bucharest. Seven years later, the program was canceled again.

Prior to Communism, Romanian sociology was an important influence changing the Romanian society. After 1947, when the monarchy was abolished and Romania was proclaimed a "popular republic," major changes took place in Romanian society.

On June 11,1948 , the primary means of production in Romania was nationalized, and the investment of foreign capital was removed and effectively eliminated. In 1962, agriculture became a co-operative; all landowners were deposed by force from their land. All those who were rich and had many possessions were arrested and forced to work in a huge building project: a waterway between the Danube River and the Black Sea. The project resulted in untold numbers of deaths due to construction hazards and poor working conditions. Based on the Communist ideology, the state became the absolute owner of all resources and economic factors.

The quality of social life gradually diminished under Communism. Increasing numbers of people lost their ideals of good and healthy relationships within the society. The Romanian notion of "private" was replaced with the Communist ideal of "collective goods." The new political system promised a better life, better quality of relationships, happiness without precedent, and a future without fear and worries. Communism promised to change the nature of human beings so that hate, jealousy, war, and dishonesty would be eradicated forever.

Rather than achieving a happy life as promised and reaching "Communism's golden dream of all nations," the quality of life within the family and in society was significantly diminished. Communism encouraged individuals to betray even their 
family members, if they seemed hostile to the regime. The consequence of this act was that fear, suspicion, hate, and insincerity became rooted in Romanian society.

In attempting to encourage economic equality between people, the state reduced the value of some professions. For example, salaries of factory workers were at times greater than salaries of physicians or engineers. By overlooking individual interests and by equalizing salaries, Communism effectively induced a decreased motivation to work among members of the general population. Communist policies stifled creativity and initiative, and encouraged laziness, superficiality, and an overall lack of interest in work. Work ethics were never discussed or promoted in any of the state institutions.

The Romanian Communist Party leaders became leaders of a totalitarian state, always appearing to receive voter support in excess of 99 percent. From the commencement of Communist control in Romania, everything became enslaved to the state's power: the mass media, the popular culture, and even the art. Everything was limited to socialist values. The idea of social homogenization (the elimination of individual differences) precipitated a series of unrighteous acts, because social righteousness could exist only in the presence of inequality.

Socialism in Romania attempted to implement the idea of equality not only within the society, but also within the family. The idea of equality is perverted by the Marxist ideology, leading to role confusion. The Romanian woman began losing her femininity and her traditional role within the family when forced to work in physically demanding professions such as construction, the steel industry, and others, in order to promote gender equality.

In March 1965, the general secretary of the Communist Party and the president of 
Romania, Georghiu Dej died. Nicolae Ceausescu as the second in the Communist hierarchy became the president. As a younger leader he decided on reforms that helped him to reach the highest position in the Communist Party. He introduced economic and industrial reforms with the wide support of the industrial nations of the world. His desire was to maintain the village as a warehouse for agricultural products; for this reason he invested in the best and newest technology in big urban centers.

As a direct result of the policies promoted under his administration, this period is marked by a migration from rural to urban areas, with a direct impact on the family, both financially and socially. The traditional, multi-generational family, which included adult children living under the same roof with their parents, began to be replaced by modern families where children were independent of the authority and financial control of their parents.

Some advantages of the migration to the cities are worth noting: individuals and families living in urban areas gained greater comforts and conveniences, greater financial stability, and better educational opportunities for their children. The urban, working class eventually became the leading class of Romanian Communist society; its members living in apartments in urban areas and receiving regular salaries. Conversely, the rural areas became depopulated, feminized, and aged. Rural communities lost their identities due to urbanization and industrialization. Those who remained in rural areas had two choices: to work in socialist organizations called "Cooperative Farms," or to maintain very small farms and to be continually warned of dispossession in case of not working in Cooperative Farms. For their labor, these workers received very few vegetables, grain or corn, and little money. 
The standard of living was pretty low during Ceausescu's reign, especially after 1980 when he decided to export a high percentage of agricultural products. Television sets existed in almost every home in the 1980s, but TV was a means of political propaganda. Cars were a luxury. Nevertheless, the movement from an old, simple house with an outhouse in the backyard, to an apartment with two or three bedrooms and indoor plumbing was a notable difference. For this reason, the Romanian people were content with little.

The political influence of Ceausescu's wife, Elena (who completed just seven grades of schooling, but was considered to be a scholar in chemistry), led to the promotion of women into leadership roles, in all areas of society - this also being part of the gender equality policy. At least 25 percent of an institution's leaders had to be women. As a result of this policy, some competent women were promoted into leadership roles. The criterion for gaining a leadership role, however, was not based upon competence or educational achievement, but upon the enslaving power of the state.

The goal of promoting women into leadership positions was not bad, but Romanian society had never before made such promotions. Unfortunately, basing leadership promotions on gender and political affiliation only, rather than on competency or education led to ridiculous situations. Many women were promoted to leadership directly from the working class, having only five or eight years of formal education. Such women graduated from "Stefan Gheorghiu," an academy where students were indoctrinated only in socialist politics and the Marxist ideology. Having a very poor knowledge base, women who were transformed into leaders overnight made unforgivable blunders. 
Although it promoted women publicly, the socialist system profaned woman's dignity and the right to private decision-making by introducing a law that forbade abortion. At the same time any contraceptive method was publicly condemned and scorned. The real reason for such a law did not have a religious foundation or due to conscience, but to have children was seen as an asset for the Communist Party. Within the framework of a lack of sexual education and encouragement of women (even unmarried girls) to bear children, the quality of family life was further diminished. Bearing many children, without providing them with a good education, impacted the immediate family, the sense of community, and the society as a whole.

An immediate effect of this policy was a flourishing back-door abortion market. Many pregnant women who resorted to illicit abortion methods died. Tragically, women who were exposed to such unsafe abortion practices were routinely denied necessary medical assistance, even by hospitals. Many of these unfortunate women were abandoned and left to die because of their refusal to reveal names of individuals who had performed illegal abortions.

The anti-abortion laws during the Communist regime in Romania lead to: (1) high infant mortality rates, (2) high maternal death rates, (3) high numbers of abandoned children, and (4) high rates of birth defects as a result of unsuccessful abortions.

The most severely impacted families were lower-middle class and lower class families with little or no support and no material means to obtain contraceptive methods other than illegal "back-door" abortions. Their increasing poverty also lead to a stronger determination to not have children any more, although the gross lack of education on 
family planning and the government policy promoting large families were tough elements to fight against.

The result of the abortion prohibition in Romania was an overall degradation of the quality of family life and a lack of love for many children, who were considered to be an unwelcome burden upon the family. The population growth resulting from this law increased the number of the poor, with a grave discrepancy between low-class and upperclass family size - the more educated had less children, preserving their wealth.

According to biblical principles, life is the most precious gift offered to human beings. The respect of life and the promotion of a healthy life style is a holy duty of every human being. An unborn child is a form of life that should be respected. "Thou shall not kill" (Exod 20:13), applies to the postmodern society as well, as the law of God is eternal. However, there are circumstances that create ethical dilemmas, when decisions need to be made as to whose life will preserved when pregnancies create a health risk for mother and/or fetus. Part of the dilemma also comes from the essence of God's character that led Him to create us with the freedom of choice, teaching us what to do, and then allowing people to make their own choices. However, the Communist government took away any choice by promulgating the anti-abortion laws, without providing any family planning education, or access to any contraceptive means that would allow each family to decide the size of the family they could afford and desire to have. $^{1}$

${ }^{1}$ From a personal point of view, while reinforcing the value of life, I disagree not with the substance of the laws, but with the mechanisms of control used to enforce the law, in the absence of any other family planning education/means. Historically, whenever governments stepped in to legislate moral issues, they did go against God's principle of allowing people the freedom of choice. 
Another act that deepened the family crisis in Romania was Ceausescu's decision to export 50-75 percent of all farming products in order to pay the debts of foreign creditors. Ceausescu focused his attention on Romanian agriculture, because other national industries were unproductive and less competitive on the worldwide market. The massive export of cereals and farm products led to an unprecedented crisis throughout Romania. Communist propaganda intensified during this period in order to reinforce the failing Communist system. All economic statistics were falsified, and an enormous gap between media reports and reality was evident.

"Disaccord between reality and the ideals promoted by a governing power gives birth to revolution."1 A crisis of values, marked by profiteering, corruption, lying, demagogy, and desperation, triggered a bloody and violent revolution in Romania in 1989.

After the revolution, tremendous changes occurred in all areas of Romanian life, including its economic, political, and social structures. This paper will focus on economic changes that occurred, because this area is most closely related to the paper's premise.

Before the 1989 revolution, Romania maintained a centralized economy. Every economic decision was centrally determined by Communist Party officials, including which product to produce, how much of a product to produce, and when to produce particular products. After the revolution, producers became disoriented because nearly everyone sought imported products. The Western standard of living, observed in

${ }^{1}$ Stefan Odobleja, The Consonantal Psychology (Bucharest, Romania: Scientific and Encyclopedic Publishing House, 1982), 487. 
magazines smuggled into Romania, became the goal of nearly every Romanian citizen.

Both producers and consumers were unprepared for the first liberalization of prices in November 1990. A lack of state control, a legislative vacuum, and psychological disorientation created a climate for economic confusion. Co-operative farms and inland water transport systems received the highest levels of plunder during the economic transition. For many years, Romanians experienced economic imbalance, which contributed to a real crisis of values. In order to heal the Romanian social climate, it was necessary to reestablish morality as a social value.

Petre Andrei (1997) caught a glimpse of the relationship between historic events and the reflection of values: "Today, in a special way, democracy is criticized by many, sometimes deserved, other times undeserved. But the defects that can be observed in the function of mechanism of democracy are not without relationship with the understanding of the idea of right, of general interest and the duty, so it is not possible to speak about the fight for the respect of the right and the overcome of abuses, as long as it is not developed by culture a strong conscience in every individual."

Democracy without culture is a disaster, particularly during times of radical transformations when old values are replaced with values aligned to present needs. Such transitions are always dramatic. Until the establishment of a new value system is complete, the meaning of good and evil, happiness and sadness, and freedom or lack of freedom may be poorly comprehended.

When a society's values are dramatically transformed, certain elements and ideals allow individuals to advance. Such ideals must be defended and cultivated. Conversely,

${ }^{1}$ Cristina Arvatu, Family in Transition (Bucuresti, Romania: The Day, Bucuresti, March 20, 2003). 
some traditions may be stifling. To defend these is to persist in error.

\section{Fall of the Communist Regime and Its Impact on Family Life}

In December 1989, a wave of freedom swept over Romania, as was the case in many countries from Eastern Europe. The lack of basic aspects of liberty that had accumulated year after year created an internal tension that erupted one day when a regular popular meeting designated to praise the dictator changed into an open revolt. Freedom was something new for almost all people in Romania. A misunderstanding of freedom generated the idea that man may do whatever he wants, and that the greatest rights belong to those who maintain high social status or wealth. Plurality of parties in Romania created thousands of political parties overnight, each with varied programs and ideologies. These were at times unintelligible and conflicting.

During an economic, social, and political crisis, very few people prosper economically. The majority of the population is stretched to the limits of subsistence. At present, nearly every Romanian citizen expects some larger events to put an end to the crisis that produced so much suffering in the Romanian family. Their hopes are focused upon the goal of belonging to the European Union. Economic and political needs, certitudes, hope for the present and future, acts of civilization and political-institutional structures, imperatives of the innovations of history, and new dimensions of international rapport, all converge in this project.

The integration of Romania into the democratic Europe polarizes energies, generates efforts, maintains hopes, and exhibits a huge mobilized force. Romanian citizens are increasingly motivated as the nation experiences the transition generated by a 
loss of jobs. As in a domino game, the loss of jobs generates poverty and poverty generates an international search for jobs. Employment in Western countries is seen as a solution to poverty.

According to a survey conducted by the Romanian Government, employment abroad showed the following increases:

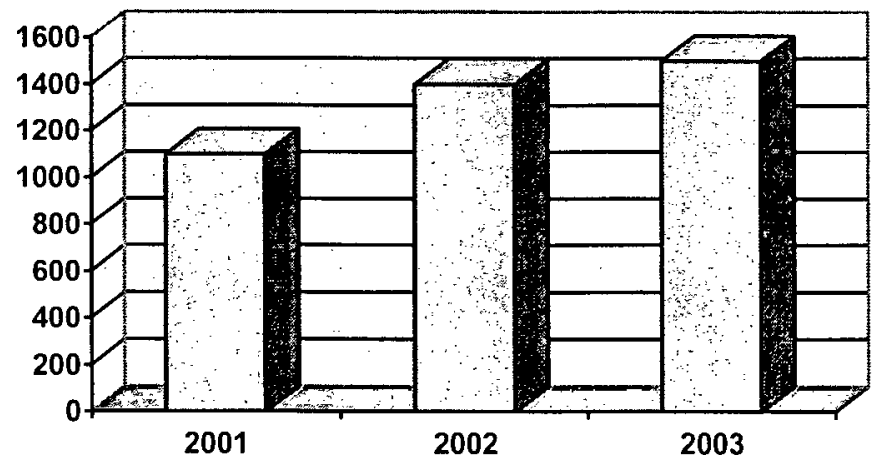

DMoney sent by Banks

Fig. 1. Romanian employment abroad. In 2001, 1.1 billion euro was sent back to Romania; in 2002, 1.4 billion euro; and in 2003, 1.5 billion euro. Source: http://etransport.ro/pp22.php?a=3/35\&p=2 .

And to this amount of money add two or three times the amount of money sent by friends or relatives or brought personally from Western countries. The government report also presents the following information: 


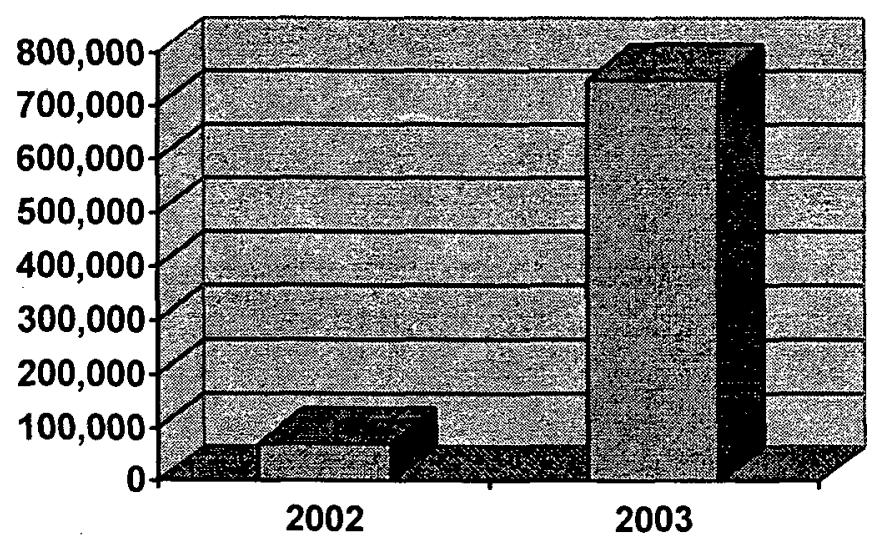

Fig. 2. The number of workers legally sent abroad in 2002 was 72,000 . The number of workers in 2003 in different countries was between 700,000-800,000. To get a more accurate picture, note that the number of workers that work illegally is at least double Migrating or Commuting. Source: http:// www.eumap.org/journal/features/ 2006 migration/pt1/commuting.

These statistics show the impossibility of assimilation of the workforce into the Romanian economy and social services.

After 1989, Romania entered into the "good world" with all manner of misfortune including: criminality, joblessness, prostitution, illiteracy, and juvenile delinquency.

Only four years after the Romanian revolution, one million individuals were officially registered as being unemployed. A number of those officially registered as being unemployed sought positions abroad, while another segment of registered unemployed citizens became delinquent. For most families, such social decadence becomes the wellspring of many other problems. If the unemployment phenomenon were an isolated one affecting only the state's budget, the problem might be manageable. But this problem caused other major social issues, including an alarming decrease in birthrate 
due primarily to an explosion of abortion rates, mainly among very young women. This drop in birthrates is estimated to lead to an accelerated aging of the population creating yet other economic problem related to retirement benefits and poverty rates among the elderly population that is increasing in numbers.

Other social problems facing the post-Communist Romania are: decreased school attendance, increased ethnic discrimination, increased mortality, and a decline in the health of the general population. All these elements result in an overall decrease of the quality of life. Feelings of dissatisfaction, uselessness, and social exclusion lead many unemployed citizens to choose drastic solutions such as criminal behaviors or suicide.. Paralleling the phenomenon of the unemployed in Romania, a very small, elite group of people held privileged and important public positions, accumulated vast sums of money, or gathered real estate properties and expensive mansions.

Speaking about Christian life generally and the Seventh-day Adventist Church especially, it is evident that freedom of speech, freedom of religious meetings and preaching, and freedom of sharing openly your faith is now a reality. On the other hand, the same economic challenges that confront Romanian secular society are present among our members. Due to this our churches decreased dramatically in numbers and many competent leaders of the churches decided to sustain their families financially by working abroad.

The Post-Communist Crisis-Social, Economic, Political, and Cultural Factors Influencing Family Life

In Romania, as in nearly all cultures, the family is the core of society, the transmitter of every traditional value and the main socialization context for children. 
Family life is the center of other activities, and it offers the best place for raising and educating the new generation. During the past fourteen years, various factors exerted pressure upon Romanian families. These factors gradually altered the function and role that family plays in Romanian society. When Communism was abolished in 1989 , Romania opened its borders to allow international travel. Concurrently, Western life styles were "imported" into the country, and the Romanian family was negatively affected by economic and social factors. Prior to 1989 , economic standards in Romania were not good. After the 1989 revolution, however, the country experienced an unprecedented decline: the importation of Western life styles together with economic deterioration and social challenges affected the family. The initial consequence of this collapse occurred when families experienced a considerable economic decline and corresponding loss of quality of life. As a result, individuals lacked the financial resources necessary to start new families. Birthrates and marriages declined. The initial political approach was to fill the market with imported goods to gain political support, and then inflation was out of control, with salaries being continuously increased with the prices. Eventually the ability of the government to subsidize goods and services decreased, and unemployment increased, leading to a severe economic crisis.

An economic crash of a country results not only in less money, but also an increase in unemployment rates as the crisis deteriorates. In order to establish a family, individuals must be able to obtain a home and an income.

According to a UNICEF report entitled "The Burden of a Decade in Transition-The Situation of the Family in Romania," researchers report that $83 \%$ of young people under the age of 29 live in the same household with their parents. Thirty percent of young people between the ages of 18 and 30 are financially dependent on their parents. For these reasons, many young people prefer alternate forms of cohabitation, "consensual families," in which young people elect to live together without first 
participating in civil or religious wedding ceremonies. ${ }^{1}$

The reason of this unusual picture can be understood if we combine two factors: the lack of means and the lack of accessibility to day care or after school programs for children. It is difficult for parents who work ten to twelve hours each day to be with their children, give them proper nurturance, and supervise them. When children are left alone or under the care of their grandparents, they determine their own activities. Often, such children find groups of other teenagers who have a bad influence upon them; many become juvenile delinquents.

Few Romanians maintain hope that this situation will improve in the near future. Many people declared that last year was worse than two years ago, and that this year is worse than last year. The Romanian economy shows no signs of improving in the next year, due to inflation and high rates of unemployment.

For many Romanian couples, the only way to obtain even a minimal income is for both partners to have at least two jobs. In this situation, "large numbers of couples have adopted a life-style in which both members have jobs outside the home and share the work of parenting.,"2 In some cases, one spouse seeks better paying employment abroad. As we shall see, this brought material advantages and new opportunities, a new condition of life, that is believed to be superior to the Communist times. At the same time more material goods means more time spent outside the house and less time for children, for fellowship, and for family.

${ }^{1} \mathrm{UNICEF}$, The Burden of a Decade in Transition-The Situation of the Family in Romania (Bucharest, Romania: United Nations Children's Fund, 2000), 20.

${ }^{2}$ Niall Bolger, Anita DeLongis, Ronald C. Kessler, and Ellaine Wethington, "The Microstructure of Daily Role-Related Stress in Married Couples," in Stress Between Work and Family, eds. John Eckenrode and Susan Gore (New York: Plenum Press, 1990), 95. 
Although many hope for foreign employment, very few Romanian citizens can obtain a work visa for western European countries. Therefore, the majority of them are content to find an illegal job, the worst paying positions on the black market. Many such workers fear losing their jobs, and are afraid to take vacations to visit their families. Others fear that they will not get tourist visas from their country of employment; these added challenges contribute to the gap between spouses and between parents and children. Ultimately, through repeated and unlimited separation of spouses, the foundations of the family are weakened. For example a study shows one of the consequences of separation when the relationship between spouses are weakened. It says that from ten men separated by their wives for economic reason, "the most part of the father had formed a second family with another woman."

Although, in most cases one parent remains in Romania to take care of the house and family, children are deprived of the affection of their missing parent. If their remaining parent also has a job outside the home, the gap between parents and children widens further. Children in these situations often become more attached to, and influenced by their companions and peers than to their own family members.

Although the Romanian "Family Code," states that, "In Romania the state protects the family; it supports by economic and social measures the development and consolidation of the family," the state shows little interest in offering social protection that would positively affect the family.

\footnotetext{
${ }^{1}$ Rhacel Salazar Parrenas, Servants of Globalization-Women, Migration and Domestic Work (Stanford, CA: Stanford University Press, 2001), 85.
} 
The Distribution of Roles in the Romanian Family

All societies are organized around the family system, although cultural norms may vary. Scripture says, "The Lord God made a woman from the rib he had taken out of the man, and he brought her to the man" (Gen 3:22). This is the foundation of the oldest and most stable form of human community.

Traditionally, married couples lived with their parents (family social scientists call this the "extended kinship system"). Not long ago, another type of family emerged, a "nuclear family system" where "married couples live together with their children, but with no other family members in the household.",

In the extended kinship system, parents hold more power and authority over children than in the nuclear family system. Adult children living with their parents are limited in their decision-making roles, even when they have children and spouses of their own. In Romania, the extended kinship system worked for a long time; however, the interference of the parents in the lives of their adult children created considerable difficulties.

In recent decades, the family experienced the pressure of so many changes that currently the "family" is associated with many problems. As a result of such pressure, many young people prefer cohabitation outside of marriage. Instead of being a depository for traditional values, the family is increasingly vulnerable to the attack of modern life; "living together" no longer means marriage, but is merely a mutual decision.

Due to economic conditions, the role of the Romanian woman changed. Instead

${ }^{1}$ Frank R. Scarpitti, Margaret L. Andersen, and Laura L. O’Tolle, Social Problems (New York: Addison Wesley Longman, Inc., 1996), 367. 
of being a "stay-at-home-mother" whose responsibility is to bear children and care for them, the woman now participates fully in the economy within the work force. The traditional role of adult children caring for their aged parents was replaced by the trend of placing aged parents in nursing homes, where trained individuals care for them. Minors have more authority because they now determine their time and activities, due to the absence of both parents from the home. Parents feel guilty because they cannot spend more time with their children, while also feeling strongly that they need to provide for their children, and therefore struggle to find better jobs that will continue to decrease the time they can spend at home. Some parents compensate by offering monetary favors to their children or by attempting to satisfy their child's every desire. Under this system, the wife's role continues to change from subordinate to a partner who is equal to her husband. "Social policy support for the accommodation of work and family has emerged earlier in countries with ideologies supporting equal roles in the family as well as the workplace."

The Romanian woman's new role created significant changes in familial functions, because alterations manifested at one level had a direct impact upon others. This project will focus on the distribution of roles within the Romanian family as influenced by two widely differing trends: traditionalism and modernism. By studying the evolution of the roles of husbands and wives in two geographic areas (rural and urban), and by identifying factors that contribute to the distribution of these roles, a better understanding of Romanian family dynamics may be gained. Within the framework of the family, traditionalism is associated with rural areas. Modernism, on the other hand,

\footnotetext{
${ }^{1}$ Suzan Lewis, An International Perspective on Work-Family Issues, in Integrating Work and Family, ed. Saroj Parasuraman \& Jeffery H. Greenhouse (Westport, Connecticut: Quorum Books, 1997), 101.
} 
due to better living conditions, is associated with urban areas.

A series of ancient writers described the roles of the husband and wife in family life. Every aspect of this topic may be viewed through the prism of a particular culture and tradition. In the recent past, the roles of husbands and wives were very well established. The wife's "kingdom" was always within the home. She was responsible for oversight of the growth and education of the children. In these traditional families, the husband maintained authority and power because "he brings money." Upon arriving home after eight hours of work, the husband had the right to rest or to be served by his wife because "he worked." What about his wife? Did she work as well? Was caring for children, cleaning the house, and cooking the food considered to be work? Not exactly. Everyone was content with his or her role, despite the fact that the wife lacked other choices within the framework of tradition.

Today, the modern family considers this system to be old-fashioned. The role of each family member is influenced by necessities imposed by the realities of life. For example, in order for the family to enjoy greater comfort and to obtain more technological goods, the wife must assume roles that sometimes belonged exclusively to the husband. Because of his wife's new role, a husband had to accept household responsibilities that were previously assigned to his wife. In the modern family, prosperity becomes the responsibility of both the husband and wife.

The Romanian woman's new role offers her varied perspectives and opportunities to affirm her personality outside of the home. A woman's involvement in social life enables her to develop personal dignity and to defend herself from those who accuse her of staying at home and doing a work that is of less value than paid work. 
Conflict between spouses may be initiated when the husband insists upon maintaining the traditional framework within his family, and when the traditional values of his parents and his grandparents are the standard of his family life. The result of such "stubbornness" produces tension between spouses, which in turn impacts the emotional relationship between husband and wife and may ultimately lead to divorce. An additional negative consequence, perhaps the worst, is that children are denied a positive emotional environment. Such children must pay an extremely high price for their parents' actions.

Traditionalism is present in all spheres and levels of Romanian society. It is present in the processes of socialization and in the manifestation of social factors within an individual's personality. Traditionalism is exhibited through distinctive types of social institutions, habits, and customs. It is not easy to transform the traditional system into a modern one overnight. The Communist system had a great interest in maintaining traditional family values, because such values encouraged submission and conformity.

From the other point of view, the Communist slogan, "no bread without work and no work without bread," referred to the necessity of everybody working to advance the Communist ideals. And Communism was the first system for Romania that promoted gender equality, as perverted as it was, and encouraged women to join the workforce. They also ensured equal pay for women, and equal access to education.

In the traditional family, the role of each family member is distinct and is focused on authority. Parents have authority over children and husbands have authority over wives. If an individual were to ask why must this occur, the question would remain unanswered because no one has an answer. Perhaps a "good" answer would be that "these are the rules." 
At the opposite end of the spectrum is the modern family. Modernism is different from or even contrary to traditional perceptions concerning the products of culture, institutions, forms of social organization, and modes of behavior. Modern society changes constantly. Contrary to traditionalism, modernism emphasizes the value of individualism. The wife does not hold a secondary position in the family, the husband is not the boss of the home, and the children are not totally submissive to their parents.

In addition to advantages gained by modernism, the family faces new provocations, conflicts, and disadvantages. If the wife elects to be "modern" by holding a job outside the home, she must pay a price for such a choice. "Whether a woman opts for commitment to a job, to motherhood, or to some combination of the two, she must accept the costs of what is forgone as well as the benefits of what is chosen."1

Modern Romanian families establish lifestyles with values that are distinct from the traditional Romanian lifestyle. Cooperation replaces authority. Cooperation within the modern Romanian family is sustained by the values of equality, change, and communication. The husband does not have supreme authority in family and the wife is not a stay-at-home mother.

I. Mihailescu and M. Voinea ${ }^{2}$ concluded that the Romanian family lost a considerable amount of its character as a social institution when the familial couple became more interested in the satisfaction of personal interests and less interested in the attainment of functions that society attributes to the familial institution. These elements

${ }^{1}$ Kathleen Gerson,"How Women Choose Between Employment and Family: A Development Perspective," in Families and Work, eds. Naomi Gertsel and Harriet Engel Gross (Philadelphia, PA: Temple University Press, 1987), 276.

${ }^{2}$ Maria Voinea, Family Sociology (Bucharest, Romania: University Press, 1993). 
favored major changes at the level of familial functions because the difficulties manifested at one level had a direct impact upon others.

\section{Family Functions in the Context of Separation for Economic Reasons}

\section{The Economic Function}

The family always was and will be an active factor in the economic, cultural, and political aspects of life. Money is required in order to obtain food and clothing. The house is not home and factory at the same time. Almost 100 percent of Romanian adults work outside the home, and their income is used to obtain food and products from markets.

Finally, the financial situation underwent significant changes. The modern Romanian family experiences an unbalanced budget due to sporadic income sources and/or exaggerated, unidirectional spending, generally for subsistence needs.

\section{The Socialization Function}

Because of societal changes, parents increasingly realize that they cannot transmit sufficient knowledge to their children in a home-school setting. For this reason, they entrust their children to schools where trained individuals educate their children and prepare them for modern society. In Romania home-schooling is not acknowledged as a functional educational alternative, while private schools were established only recently (after 1990) as an alternative to the public school system developed in the Communist era.

Romanian parents working outside the family (many times working abroad) spend little time with their children. Often, the care of their children is entrusted to specialized 
institutions such as crèches or kindergartens. Children spend time in such institutions from the time they are very young. In other instances, grandparents, relatives, or neighbors are entrusted with the care of the children. Often, these children do not receive the level of nurturance or education necessary to promote healthy childhood development.

Dr. Willie Richardson makes a strong statement about the parent-child relationship: "These are not the days when parents can be caught up in their personal pursuits of following a career, earning a dollar ... while neglecting to get into the world of their children." Parents not only lack necessary time for the achievement of natural socialization for their children, but they also fail to realize the necessity of educational actions.

\section{Current Problems Faced by Romanian Couples}

In the modern life, men and women exercise their right to love one another and to determine whether to spend their lives together. A marriage has a future only when both parties build their relationship on love, and do not create a marriage of convenience where parties remain together only as long as they "feel good." Arranged weddings, where parents decide who their children will marry have faded and belong to a nearly forgotten past.

Many individuals fail to comprehend the long-term significance of the family. Such individuals view the family merely as a place where sexual pleasures are met; they consider themselves to be at the center of the family and force their spouses to submit to

\footnotetext{
'Willie Richardson, Reclaiming the Urban Family (Grand Rapids, MI: Zondervan Publishing House, 1996), 237.
} 
their wishes. Conflicts in modern marital life spring initially from the limited duration of life and of passion. "Die Leidenschaft flieht, die Liebe muss bleiben," (Passion flies, but love must stay) says Schiller, the poet of bourgeois marital life. In most families blessed with children, marital love withers slowly and imperceptibly. Passion in the marriage is gradually replaced by an affectionate friendship, which from time to time is interrupted by the short flare of the old love. The parties' love becomes routine. As children grow, the youthfulness of their parents is revived for a time, until advancing age takes their strength. If there is not love, not only as a flame that burns at the maximum strength for the first five to ten years from the wedding, but also love as a principle that keeps the family together forever, it is very easy for the spouses who are separated for a while to be unfaithful to each other. The Romanian saying, "The eyes that cannot see each other, forget each other," is unfortunately true, though only when love is seen as the meaning of physical satisfaction.

This process is not the same for everyone. There are many ways in which individuals attempt to reconcile their temporary earthly pilgrimage. To those who possess the gift of faith, God grants consolation and courage. Their faith enables them to view themselves as a thread weaving patterns through the texture of eternal life. Their faith provides them with a place in the everlasting plan of the Creator of the world, and puts them beyond time and place. Their faith gives them hope beyond the grave, in the new earth.

Other individuals find satisfaction in philosophy. They refuse to believe in a beneficent Providence, whose idea is in conflict with their experience. They despise the easy imaginary comfort of a new world order, which is in conflict with the world, that 
they are forced to recognize around them.

A great majority of individuals choose another way. Not being prepared mentally to accept change, they succumb to the challenge of daily life. These individuals fail to think beyond the present moment. Ultimately, they become slaves of habits and passion.

In a society affected by moral degradation and non-Christian values, the family faces external problems related to the modern attitudes regarding family life and from inside, more and more temptations threaten the institution of marriage. On one hand the knowledge of Western life styles that penetrated Romanian society after 1990 created higher standards; on the other hand the price that a family has to pay for updating the family to these standards is very high.

Besides the struggle for a higher standard of living, there is another aspect: the necessity of surviving in an economy that daily reaches levels that challenge the family in unprecedented ways.

This is why the Romanian family is constrained to experiment with new methods of survival. One of them, and the most commonly accepted method, is to have one of the spouses working abroad in order to earn enough money to support the entire family. Even though the sad experience of more and more couples demonstrates the danger of this plan, it is hard to stop this exodus until the Romanian economy improves and creates more jobs for the population. Another option would be to better the emigration laws in Western countries that represent primary places seek by Romanian people, allowing for temporary residence and work permits.

However, emigration does not come without other social costs, severely felt by families that have to go through temporary separations in order to have a better financial 
situation. The consequences of emigration on individuals, families and local communities are well documented in the literature. Nevertheless, there is very little research being done on the Romanian society, in regards to the immediate effects of the massive exodus of the local workforce towards Western countries. 


\section{CHAPTER IV}

\section{EMIGRATION AND CONSEQUENCES OF EMIGRATION ON INDIVIDUALS, FAMILIES, AND COMMUNITIES}

\section{Introduction}

Emigration is an act of leaving a place to work and live to another place. One of the best definitions of emigration is given by Franklin D. Scott: "Man's history is a story of movement, of the conquest of land from nature and from fellow man, of adoption to new environments, of the bleeding of blood and the intermixture of culture, of a constant, restless striving for "something better."1

There are multiple reasons for emigration: political, economical, religious, from desire to reunite with the family, or simply for a better climate.

"Migration has always been a part of human life." This process of moving from one country to another is so complex and the roots of this act go back to the origin of humanity. Moses, the author of the first book of the Bible, Genesis, describes, the process of people's migration who being together decided to build a tower, well-known as the "Tower of Babel." But God's original plan was to populate the whole earth. "Be

\footnotetext{
1966), 1.

${ }^{2}$ Maura I. Toro-Morn, ed. Migration and Immigration - A Global View (Westport, Connecticut: Greenwood Press, 2004), xv.
}

${ }^{1}$ Franklin D. Scott, Emigration and Immigration (Baltimore, MD: Waverly Press, 
fruitful and increase in number; fill the earth and subdue it" (Gen 1:28). For this reason "the LORD scattered them over the face of the whole earth" (Gen 11:9). Not understanding each other, due to the confusion of their language, they decided to leave that place and to move to another land according to the likeness of the language they spoke. Starting with that moment people's migration with its positive and negative consequences continues to be a reality of our life. Regardless of culture, politic system, social environment, and geographical position for various reasons, people continue to travel from a place to another for temporary or permanent emigration.

A history of migration is largely presented in a book by Donald R. Taft (1955). Beside the history of immigration to the United States, the author has a chapter titled "A Sampling of European Nationalities." In this chapter, Taft writes about different reasons for which people like Germans, Catholic Irish, French Canadians, Italians and Jewish people migrated from their country and the history following their emigration. Reasons for emigration are so different from an individual or group to another that it is impossible to mention all of them. Sometimes the lack of religious or political liberty was the cause, other times economic reasons, in order to live a better life determined people to migrate.

It is interesting to mention that emigrants were not the only ones benefiting from their relocation in another country, but also the countries that adopted them. It will be unfair to mention just the material aspects of these advantages; cultural and social avails are of similar importance. What is written about German people relocated in the United States fits every other ethnic group that emigrated to a different country: "It is impossible 
even to summarize the many cultural contributions of the Germans stock in the United States, and as we note later the listing of "great names" can be overdone."

\section{Emigration Patterns in Romania before 1989}

Temporary or permanent migration is a process with many implications that increased dramatically after 1990 . Prior to this date Romania was under a Communist government that strongly discouraged any form of emigration. The goal of the government was to keep Romania isolated from any potential Western influences and maintain strong Communist governance tailored by the President's vision. However, for some of the ethnic minorities in Romania, such as German or Jewish and later on Hungarian people, emigration was a narrow gate out, although it was made very complicated by the many conditions to fulfill in order to visit or to permanently migrate to countries they identified as their own.

Statistics regarding the emigration before 1989 are very poor. The Communist leaders didn't have any interest to publish how many people long to leave the "Communist Paradise" in order to live in an "imperialist country." However, before 1944 when the Communist system was established in Romania, we have reports about people who exercised their right to choose the country where they want to live in. Here is an example: "Statistics about the number of migrants from Romania to Palestine (192224), Argentina (1921-24), Brazil (1908-24), Canada (1900-24), Cuba (1911-24), and the United States (1880-1924) will be found in the national tables for those countries."

\footnotetext{
${ }^{1}$ Donald R. Taft, International Migration-The Immigrant in the Modern World (New York, NY: The Ronald Press Company, 1955), 469.

${ }^{2}$ Walter Willcox, ed. International Migration (New York, NY: Arno Press and The New York Times, 1970), 875.
} 
Temporary migration was seen as a real adventure due to the legislation that discouraged any travel abroad. We can talk about three types of emigration: small trade, visits to the relatives, and emigration for work.

Small trade emigration started by trips to countries close to Romania such as Poland, Turkey, and ex-Yugoslavia. A passport was very difficult to acquire and always was preceded by a personal appointment with the chief of the police or one of his men who were trying to persuade the passport solicitant to become an informer reporting on Romanian people living abroad. Before or after traveling abroad, the passport couldn't be kept by the owner, but returned to the Police station in twenty-four hours. The author of this dissertation knows personally the difficulties of getting a passport and traveling as a tourist abroad in 1980.

If temporary emigration was very hard to achieve, permanent emigration was a Calvary. Beginning with 1970, Romanian media started a brutal campaign focusing on two points: to praise good conditions of life in Romania under the "clever guidance" of Ceausescu and to discourage possible emigrants by emotional abuse or blaming them as traitors. "Spokespersons for ethnic minorities in the workers' councils praised the regime's treatment of minorities and declared their devotion to socialist Romania. By contrast, those who desired to emigrate were depicted as weaklings with underdeveloped "patriotic and political consciousness," would-be traitors abandoning their fatherland and the struggle to build socialism. Stories abounded of Romanians emigrating only to find 
life more difficult in their new environment and happily returning to their homeland. Accounts of those who had immigrated to West Germany were particularly bleak."

The consequences of applying for permanent emigration were of short and long term. First of all the process of emigration was exhaustive and costly. The immediate consequences of the decision to leave Romania were the loss of employment and the exposure to the community as a traitor. The loss of property followed shortly after, houses being confiscated without any reimbursement to the owner. Constant emotional and sometimes physical abuse were common practices by the secret police aiming to intimidate not only people who applied for a permit of emigration, but also those who were thinking about it, making each situation a "learning" opportunity for the rest of the country.

Another mechanism used to discourage emigration was a government-imposed tax claimed to cover all state expenses for the education of the ones that decided to emigrate-taking into account the fact that education was free for Romanian citizens but not so for the ones that decided to leave and therefore affect the return on the government investment in their education. Although it was illegal to possess foreign currency and the monthly salary was around $\$ 100 /$ month, for every person that would leave the country had to pay an emigration tax of $\$ 20,000 /$ emigrant. "Sums of up to $\$ 20,000$ in hard currency were to be paid before emigrants would be allowed to leave. ${ }^{22}$ Fortunately, this tax was never enforced due to the pressure of the United States. Other Western countries, such as Germany, the government had an agreement with Romania to pay for each person

\footnotetext{
'Romania-Emigration: Problem or Solution? http://www.country-data.com/cgibin/query/r-11151.html (July 5, 2006).

${ }^{2}$ Ibid.Romania-Emigration: Problem or Solution?
} 
that emigrated DM5,000 (around $\$ 4,000$ ). ${ }^{1}$ Even in this situation, a prospective emigrant had to pay a lot of unofficial taxes (bribe) to different people who were promising to resolve their files.

In spite of all these troubles, during the " 70 s and the ' 80 s, emigration rates sharply increased. According to the statistics from that time, German and Jewish people were at the top of the list.

Despite Ceausescu's opposition to emigration, the ethnic German population declined sharply. In 1967, when diplomatic relations with West Germany were established, roughly 60,000 ethnic Germans requested permission to emigrate. By 1978 , some 80,000 had departed for West Germany. In 1978 the two countries negotiated an agreement concerning the remaining German population, which had decreased from 2 percent of the total population in 1966 to 1.6 percent in 1977. Romania agreed to allow 11,000 to 13,000 ethnic Germans to emigrate each year in return for hard currency and a payment of DM5,000 per person to reimburse the state for educational expenses. In 1982 that figure rose to DM7,000-8,000 per person. In the decade between 1978 and 1988, approximately 120,000 Germans emigrated, leaving behind a population of only about 200,000 , between 80 and 90 percent of whom wanted to emigrate. As their numbers declined, the Germans feared they would be less able to resist assimilation. In 1987 an entire village of some 200 ethnic Germans applied en masse for emigration permits. ${ }^{2}$

The Jewish people knew even a worse treatment due to the anti-Semitism manifested and encouraged by the Communist regime.

The Jewish minority also markedly declined as a result of large-scale emigration. Suffering under state-fostered anti-Semitism and financially ruined by expropriations during nationalization, much of the Jewish population applied for permission to leave in 1948. Between 1948 and 1951, 117,950 Jews emigrated to Israel, and from 1958 to $1964,90,000$ more followed, leaving a total Jewish population of only 43,000 in 1966. Permission to emigrate was freely granted to Jews, and by 1988 the population numbered between 20,000 and 25,000 , half of whom were more than sixty-five years of age. ${ }^{3}$

'Tbid.

${ }^{2}$ Ibid.

${ }^{3}$ Ibid. 
Before 1989 the migration toward Israel was permitted just for Jewish people who could prove their origin. According to Dana Diminescu, "Between 1961 and 1964, 63,546 Romanian Jewish people reached Israel pursuant to an agreement between the two states. The emigration of the Jewish people from Romania continued throughout the 1970s and the 1980s, albeit at a lower rate."

\section{Reasons for Emigration}

Even though there is a long list of potential reasons for emigration, we will present here just some of them that are in close connection to the topic of this paper.

1. Denial of the right to a free speech. First of all the main factor that contributed to the decision to leave the country was the denial of the right to a free speech. Even though many political, social and cultural aspects led to a wrong direction, the only "right" as a citizen was to acknowledge and praise the "wisdom" and the "smart vision" of the President, and by all means to help developing Communism, "the golden dream of all nations." This total denial of the right to a free speech lead many of the Romanian intellectual people to choose emigration, despite all the barriers and difficulties such a decision would create.

Ceausescu's methods to keep the intellectuality under control were well presented and discussed by William Totok ${ }^{2}$ a German ex-ambassador in Romania from 1971-

\section{${ }^{1}$ Dana Diminescu, ed., Visible, But Not Very Numerous. The Romanian} Migratory Circouites (Paris, France: Editions of the House of the Sciences of the Man, 2003), 5.

\footnotetext{
${ }^{2}$ William Totok, Romania of the 70's: A Naked Truth (Stuttgart-Munich, Germany: German Publishing House, 2001), 542.
} 
1976. In his book he writes about the conflict between Ceausescu and intellectuals; about Ceausescu's fear of this group of people who still had courage to think differently.

2. Access to better education. Another reason for emigration was the desire for a better and more open education and something different from Communism for their children. The system to educate children in the Communist spirit, interdicting them to give them an education according to their convictions and instructing them politicallyoriented from the preschool ages, has been seen by some parents as a real and dangerous perspective.

3. Lack of religious freedom. Even though it was not a large group, some emigrated choosing a country with religious liberty for them and their families. Beside the daily stress sprouted from a Communism oriented ideology, the religious persecution and constant warning of firing was too much for them. ${ }^{1}$

4. Family reunification. The desire to reunite with family members that immigrated to other countries made some people emigrate. The dream of many young people was to have opportunity to marry with a foreign partner and to leave Romania to have an easier lifestyle. Even though this happened; the process of emigration was long and exhausted. Years and years the newlywed had to wait until they get the approval for emigration. Ironically, the government recommended them to reunite the family on the territory of Romania.

5. Economic reasons. A large number of people who decided to emigrate were pursuing better lives and the accumulation of wealth that was not possible under the Communist regime. Some of them had opportunity to travel abroad as tourists or to visit

\footnotetext{
${ }^{1}$ The author of this dissertation got to experience, first hand, some of the government oppression against religious freedom.
} 
their relatives living in foreign countries. They had opportunity to compare the living standard of people from these countries with Romania's people, and encouraged by their relatives or friends, decided to emigrate. Due to the good politic relationships between Romania and Iraq, only in this country Romanian people had opportunity to work officially. In order to get a labor contract for work in Iraq the applicant had to pay large amounts of money as bribe to one or more persons in charge with recruiting the work forces. Even though conditions for work in Iraq were worse than in Romania, many workers longed for a labor contract in this country, due to the material advantage: his family continued to receive the monthly salary in Romania, and the workers got a better remuneration in Iraq.

\section{Emigration from Romania, after 1989}

One of the first changes introduced by the new government, after the fall of the Communist regime in 1989, was to allow the freedom of movement, for all Romanian citizens. The first step towards making this change official was to issue passports to all citizens that applied for a passport. The second step, implying international cooperation, was to open the borders towards neighboring and Western countries. Emigration became a right for all Romanian citizens.

Due to the increase of unemployment in a special in urban area, many families found themselves in the impossibility to sustain the cost of the high living. Some of them decided to migrate in a rural area where they could have their own farms for fruits and vegetables, or being born and raised in the rural area, they simple return home where their parents offered land and material support. 
On the other hand, many people, attracted by the western countries' mirage decided to emigrate, the primary reason supporting their decision being to provide financial support for their families. At the same time, "Many Northern European countries encouraged and received labor migrants admitted ostensibly for short periods of time..."1 due to their need for a cheap working hand or because it was difficult for them to find native workers in some area such as construction or agriculture.

Before 1989, just several countries such as Germany, the United States and Hungary attracted Romanian people, looking for permanent residence for reasons presented above. When Romanian borders were open, new countries pulled attention not only of Romanian possible emigrants, but also of the large population from Eastern countries. Due to the work opportunities, countries such as Italy, Spain, France, Canada and England involuntarily attracted people from countries that got the right to travel abroad. "The emigration toward Israel however is the opposite of a declining flow in absolute and relative terms."

Before 1989 the migration toward Israel was permitted just for Jewish people who could prove their origin. According to Dana Diminescu3: "Between 1961 and 1964, 63,546 Romanian Jewish people reached Israel, pursuant to an agreement between the two states." The emigration of Jews continued throughout the 1970 s and the 1980 s, albeit at a lower rate.

'Monica Boyd, "Family and Personal Networks in International Migration: Recent Developments and New Agendas," International Migration Review, 23, no. 3, Special Silver Anniversary Issue: International Migration an Assessment for the 90's (Autumn, 1989), 638-670.

${ }^{2}$ Dumitru Sandu, Patterns of Temporary Emigration: Experiences and Intentions at Individual and Community Levels (Bucharest, Romania: University of Bucharest Press 2005), 3 .

${ }^{3}$ Dana Diminescu, ed., Visible, But Not Very Numerous: The Romanian Migratory Circouites (Paris, France: Editions of the House of the Sciences of the Man, 2003), 5. 
In order to know what countries did Romanians emigrate for the past 10 years, E-migrant.ro developed and administered a survey; ${ }^{1} 4,945$ respondents participated to this survey. The question was: "Romanian emigrants are all over the world. Where do you live?" See table 1 for their answers:

Table 1. Romanian Online Survey.

\begin{tabular}{|l|l|l|}
\hline I live in Romania but I am thinking to emigrate & 617 & $12.5 \%$ \\
\hline I don't have a stabile domicile & 53 & $1.1 \%$ \\
\hline I don't emigrate & 199 & $4.0 \%$ \\
\hline Other country & 505 & $10.2 \%$ \\
\hline Romanians in Spain & 553 & $11.2 \%$ \\
\hline Romanians in America & 607 & $12.3 \%$ \\
\hline Romanians in The United Kingdoms & 200 & $4.0 \%$ \\
\hline Romanians in Canada & 501 & $10.1 \%$ \\
\hline Romanians in Germany & 425 & $8.6 \%$ \\
\hline Romanians in France & 317 & $6.4 \%$ \\
\hline Romanians in Italy & 729 & $14.7 \%$ \\
\hline Romanians in Holland & 239 & $4.8 \%$ \\
\hline
\end{tabular}

${ }^{1}$ http://www.e-migrant.ro/rezultatele_sondajului.php?poll=test (June 30, 2006). 
The results of this survey show that Italy, the United States and Spain are countries on the top of preferences for Romanians. Some potential explanations for choosing these countries are: they provide more job opportunities for emigrants; and the legislation in these countries offers opportunity to work legally and eventually becomes a permanent resident. Another important finding of this survey is the percentage of people who are thinking to emigrate (12.5 percent).

The main reason for such a great wave of emigrations was the crash of the Romanian economy after 1989 that led to a dramatic decrease of jobs. This was helped by the fact that, with the fall of the Communist regime, passports were suddenly accessible to Romanian citizens, and so was the Western world. The borders opened unrestrictedly immediately after 1989. Those days, the Office for Passports were assailed by hundred of thousands of Romanians whose desire were to travel abroad. But the borders were close short thereafter, and the legislation changed due to the great exodus of Romanians towards the West. Then, the legislation changed again, trying to regulate emigration by the requirement to prove possession of financial means to support yourself when you travel abroad.

Among the most demanded jobs according to "The Truth," , are: construction jobs, house keeping in the hotel industry, and nursing. Strangely, the most wanted jobs by Romanian people are in agriculture and gardening, because this area requires less work experience and very limited language proficiency.

"Romanian Money from Abroad Help the National Economy," The Truth (Bucharest), June 29, 2006. 


\section{Consequences of Partial Emigration on Individuals and Families}

To better understand the complexity of this phenomenon, we have to take in consideration both the positive and the negative consequences of emigration.

\section{Positive Consequences}

\section{Immediate Economic Improvement}

Legally or illegally, a large number of families confronted with poverty and lack of means for a better education for their children discovered in the western countries a real golden mine. One advantage for both sides (seasonal workers and the employer) is that the employer pays less money to the emigrant than to a native citizen of their countries, and the seasonal workers earn much more than he/she could ever earn in the countries they left. According to the Romanian National Bank, "The amount of money Romanian citizens abroad sent back in the country in 2005 exceeded 4 billion euro, according to a statistical report the Romanian National Bank." This money had a huge economic impact on the welfare of Romanian families confronted with an economy that year by year tends to be weaker or that doesn't show any sign of strengthening. More than that a substantial bank account gave more confidence for future and lifted up the burden of concern regarding the rising living costs in Romania.

\section{Accumulation of Wealth and Status}

As a social consequence we need to mention the accumulation of wealth and status and the ability to better provide for the family. As I already mentioned, people

${ }^{1}$ HotNews, February 23, 2006, http://english.hotnews.ro/Romanians-abroad-sentback-4.3-billion-euro-in-2005-articol_42143.htm (July 1, 2006). 
who had opportunity to work abroad, increased the well-being of their family, in many cases bringing the Western life standard within their homes.

\section{Improved Work Ethics}

Another positive consequence of the emigration on individual is the opportunity of those who came in contact with the western civilization and work abroad, to have a better understanding of the work's discipline and coming home to use this new mentality. By the equalization of salary to all categories of employees, the Communist system established a mentality of idleness and lack of interest. Now, Romanian emigrants had opportunity to come in contact with another side of discipline of work.

\section{Negative Consequences}

All changes incur not only benefits but also significant costs. There are short and long term negative consequences of emigration we need to consider.

\section{Marital and Family Problems Due to Temporary Separation}

One immediate negative consequence is the weakening of relationships between spouses and between the parent who worked abroad and the children. Being separated for a period of six months to a year(s) without many opportunities to see each other due to legislation that suspended the right to reentry in the country once they overstayed their right to be in that country; limited communication (just phone or mail contact) often is the most serious barrier in preserving the family unit during extended couple separation. Physical separation often results in emotional distance between spouses. This emotional distance leads to separate lives that often end with infidelity on either sides or both. 


\section{Lack of Emotional Support}

When God said, "It is not good for the man to be alone. I will make a helper suitable for him" (Gen 2:18), He knew the importance of emotional support. God created the institution of family as a place where both spouses have a role to sustain, encourage, give and receive physical and emotional support. In a special way in time of crisis, when one of the spouses is separated from his family for different reasons, the lack of this kind of intimacy can bring unpredictable consequences. Too often the lack of communication leads to depression, and sometimes suicide is just the next step.

\section{Consequences of Emigration on Community \\ Increased Standards of Living through Improvement of Local Infrastructure}

The right to own a passport and the elimination of visas for Schengen space gave to each individual opportunity to travel abroad. Money earned by people working abroad and sent home had an impact not only on families and individual but also on the community. New houses were built, new projects of the community such as better conditions for children in schools by equipping labs with modern technology, or new buildings for the local church, came into being.

\section{Leadership Development}

In the local church, emigration gave opportunity to a new generation of leaders to demonstrate their ability in leadership. Due to the conservative mentality a leader once elected in a position in the church, he will remain in that position tens of years. Now, by traveling abroad for a long time, new leaders took their place and a new leadership brought freshness and newness to the church. 


\section{Human Trafficking}

Beside all these positive consequences, there were some negative aspects that threw a shadow on community. "In the summer of 2002 there emerged a third migration wave consisting of minors, prostitutes, and persons with handicaps used as panhandlers. Although not very numerous, this category is quite visible." This picture was like a dirty stain on the Romania's face.

Many persons from this category, unfortunately some of them very young children, emigrated for economic reasons, "thinking they would get a well-paid job at a restaurant, at a bar or as a ballerina" after answering employment ads, Ulrich said. The women instead ended up being forced to work as prostitutes. . . According to unofficial statistics, hundreds of Romanian women work abroad as prostitutes."2

The statistic from 2003 reveals, "A significant component of illegal migration is human trafficking. Twenty-six human trafficking networks were uncovered in 2003, in which 77 individuals trafficked in over 600 women for prostitution and another 480 individuals for panhandling."

This phenomenon is so spread that The Council of Europe adopted a recommendation saying, "Considering that trafficking in human beings for the purpose of sexual exploitation extends well beyond national borders, and that it is therefore

'Dana Diminescu, ed., Visible, But Not Very Numerous. The Romanian Migratory Circouites (Paris, France: Editions of the House of the Sciences of the Man, 2003), 21.

${ }^{2}$ Melanie Orhant, "Romanian Women Work as Prostitutes Abroad," The Associated Press, October 25, 2000.

${ }^{3}$ Aurel Neagu, "Illegal Migration at Romanian Borders," (paper delivered at the Migrationsfragen und Minderheitenrechte in Europe International Symposium, GoetheInstitute, Bucharest, 29-30 März 2004). 
necessary to establish a pan-European strategy to combat this phenomenon and protect its victims. ... Condemns trafficking in human beings for the purpose of sexual exploitation, which constitutes a violation of human rights and an offence to the dignity and the integrity of the human being."1

\section{Brain Drainage}

After 1989 many countries with a strong economy such as, Germany, France, Italy, Japan, the United States, and others, created opportunities for Romanian young people gifted with a good intellectual potential to study and then to work abroad. The import of intellectual brains practiced by countries with a healthy economy, linked with the lack of job opportunities in Romania, had a more negative impact on the Romanian economy. An apartment and a well-paid job in a company that knows to respect and appreciate the human dignity, in a Western country, was and continues to be the dream of every Romanian young man.

Due to Romanian economy that doesn't offer a healing sign, and the international tendencies, the analysts of migration phenomenon don't see any improvement in emigration issue, at least in the next years. "Considering the current international tendencies, the international migration of Romanian citizens will continue at the same rates or will increase. Economic estimates show that Western Europe needs to rely on

'Council of Europe Committee of Ministers, "Action Against Trafficking in Human Beings for the Purpose of Sexual Exploitation," Recommendation No. R (2000), 13 of the Committee of Ministers to Member States on a European Policy on Trafficking in Human Being (adopted by the Committee of Ministers on 13 July 2000, at the 710th meeting of the Ministers' Deputies). 
immigration in the future, even beyond the existing level. From this perspective, the best qualified workforce remains that of Central and Eastern Europe."

\section{Conclusion}

There is a pattern of migration in Romania before 1989, as the Romanian people, for different reasons (economic or occupational) relocated from rural to urban areas as result of the urbanization process in the 1960s and 1970s, or from one geographical region of the country to another, following job placements that were not necessarily linked to the place of residence. As we mentioned at the beginning of this section, we do witness a particular pattern of emigration before 1989 that was strongly discouraged by existing laws, and attracted serious consequences when pursued. However, all these forms of migration during Communism were limited by the fact that most of the jobs, once secured, were jobs for life. As a consequence, there is little migration around the country for most people during that time, with some exceptions for medical doctors, who had to go through residency before getting a permanent job, for army employees that were transferred from one unit to another based on job requirements, and for the Protestant clergy, for which the policy was to not spend more than a limited period of time (an average of five years) in one location.

Towards the end of the Communist regime, the increased political coercion as well as the rapidly deteriorating economy determined a change in emigration patterns with more and more Romanian people pursuing temporary or permanent emigration. The phenomenon intensified after 1989, when the Romanian revolution leading to the fall of

\footnotetext{
'Peter McDonald and Rebecca Kippen, "Labor Supply Prospects in 16 Developed Countries, 2000-2050," Population and Development Review 27, no. 1 (2001).
} 
the Communist regime, opened the borders and gave to every Romanian citizen opportunity to own a passport and travel abroad. The transition to a market economy contributed even more to increased emigration rates, with all consequences listed above.

There are different reasons for emigration but the main cause remains the economic purpose which for many families is the only method for surviving. Temporary or permanent emigration is not an ideal solution for families confronted with poverty and lack of means for education for their children and a secure future, but as long as the Romanian economy will not give signs of healing, emigration will continue to be the dream of more and more people.

There are positive and negative consequences of emigration on individual, family and community. These effects can be seen in Romania, in a special way after 1989, when migration increased dramatically. The emigration process cannot be stopped. But it can monitor and the government should focus on causes instead of effects of emigration. "In the middle of transition, Romania now needs more effective control of international migration flows focusing on the reduction of the labor force and its effects on social budgets."

${ }^{1}$ Ionel Muntele, International Migrations in Modern and Contemporary Romania, in Dana Diminescu, 46. 


\section{CHAPTER V}

\section{METHODOLOGY AND FINDINGS}

\section{Methodology}

In March 2003 a survey was used to gather information about families affected by separation due to economic reasons in Romania. To ensure a sample that will permit some level of generalization to the larger Adventist community, we used a stratified purposive sampling in selecting the churches to which the survey will be distributed. The survey was distributed in all six conferences of the Romanian Union of Seventh-day Adventist Churches. The author of the dissertation traveled in Romania to organize the survey and conducted the survey in one of the largest Adventist churches in Bucharest. For the rest of the Adventist churches where the survey was conducted, the author collaborated with the pastors of these churches, trained them, and gave detailed instructions regarding the survey in order to collect the most accurate information needed. The sample was stratified by geographical location (rural or urban), church size, ethnicity (including ethnic churches), and to the Seventh-day Adventists with a different level of education-starting with elementary to graduate studies. A total of 1,000 surveys were distributed of which 683 completed surveys were returned with a response rate of 68 percent. All completed surveys were mailed to the author to be analyzed. 
The survey consisted of four sections, each emphasizing different aspects of temporary family separation: (1) factors leading to separation, (2) church involvement/support, (3) community involvement/support, and (4) recommended options for family crisis/economic crisis. See appendix A, Family Separation in the Seventh-day Adventist Romanian Church Survey.

\section{Characteristics of the Survey}

The sample has good representation of both men (41 percent) and women (59 percent). The respondents were mostly middle-age (over 60 percent being 30 years old or older), married (77 percent), and Seventh-day Adventist members (99 percent). The education levels were well represented, being representative for the larger Seventh-day Adventist population. The main descriptors of the population that participated in this survey are presented in table 1 . 
Table 2. Families Affected by Separation.

\begin{tabular}{|c|c|c|c|c|}
\hline & TYPE & PERCENT & TYPE & PERCENT \\
\hline Gender & Female & $59 \%$ & Male & $41 \%$ \\
\hline \multirow[t]{3}{*}{ Ethnicity } & Romanian & $89 \%$ & German & $1 \%$ \\
\hline & Hungarian & $7 \%$ & Romany (Gypsy) & $2 \%$ \\
\hline & Other & $1 \%$ & & \\
\hline \multirow[t]{3}{*}{ Age } & Under 20 years old & $6 \%$ & $41-50$ years old & $19 \%$ \\
\hline & $21-30$ years old & $31 \%$ & Over 50 & $8 \%$ \\
\hline & $31-40$ years old & $34 \%$ & & \\
\hline \multirow{2}{*}{$\begin{array}{l}\text { Marital } \\
\text { Status }\end{array}$} & Married & $77 \%$ & Widowed & $2 \%$ \\
\hline & Divorced & $0 \%$ & Single & $21 \%$ \\
\hline \multirow[t]{3}{*}{ Education } & $\begin{array}{l}\text { Elementary school ( } 4 \\
\text { years of study) }\end{array}$ & $2 \%$ & College & $25 \%$ \\
\hline & 8 years of study & $25 \%$ & Graduate studies & $17 \%$ \\
\hline & $\begin{array}{l}\text { High school ( } 12 \text { years } \\
\text { of study) }\end{array}$ & $30 \%$ & & \\
\hline \multirow{2}{*}{$\begin{array}{l}\text { Years in } \\
\text { SDA Church }\end{array}$} & $0-3$ years & $11 \%$ & $11-20$ years & $29 \%$ \\
\hline & $4-10$ years & $22 \%$ & Over 21 years & $27 \%$ \\
\hline $\begin{array}{l}\text { Church } \\
\text { Affiliation }\end{array}$ & $\begin{array}{l}\text { Seventh-day } \\
\text { Adventist }\end{array}$ & $99 \%$ & Orthodox & $1 \%$ \\
\hline
\end{tabular}

For a more in-depth understanding of the phenomenon of separation for economic reasons, a qualitative dimension to the analysis was also added. Two focus groups were conducted in Romania in March 2003. One group was comprised of pastors and administrators at the Conference level. The other group included leaders of the church at the Romanian Union. (See focus group protocol, appendix B.) A random sample of pastors was selected for participating in the focus group discussions from those involved in the family departments of the Conference and the Union of the Church. The selected participants reviewed the focus group protocol and each of them was given the option of declining participation. Each focus group lasted approximately sixty minutes. The focus 
group discussions, based on a list of questions, were conducted by the author of this study (see appendix B). The Research Questions follow:

1. What are the main factors leading to family separation in Romania?

2. How is the church/faith community responding to family crisis caused by temporary separation due to economic reasons?

3. What are some ways in which the church can better respond to the needs of Seventh-day Adventist families in Romania?

\section{Findings}

\section{Perspectives on Temporary Family Separation}

The main purpose of this study was to identify key factors leading to temporary family separation by one spouse traveling abroad to look for a job. According to the survey, it is clear that after infidelity ( 51 percent), the second most important reason for separation is financial stress ( 42 percent). Clearly, money cannot create happiness, but the lack of money is a cause of unhappiness (see figure 2). 


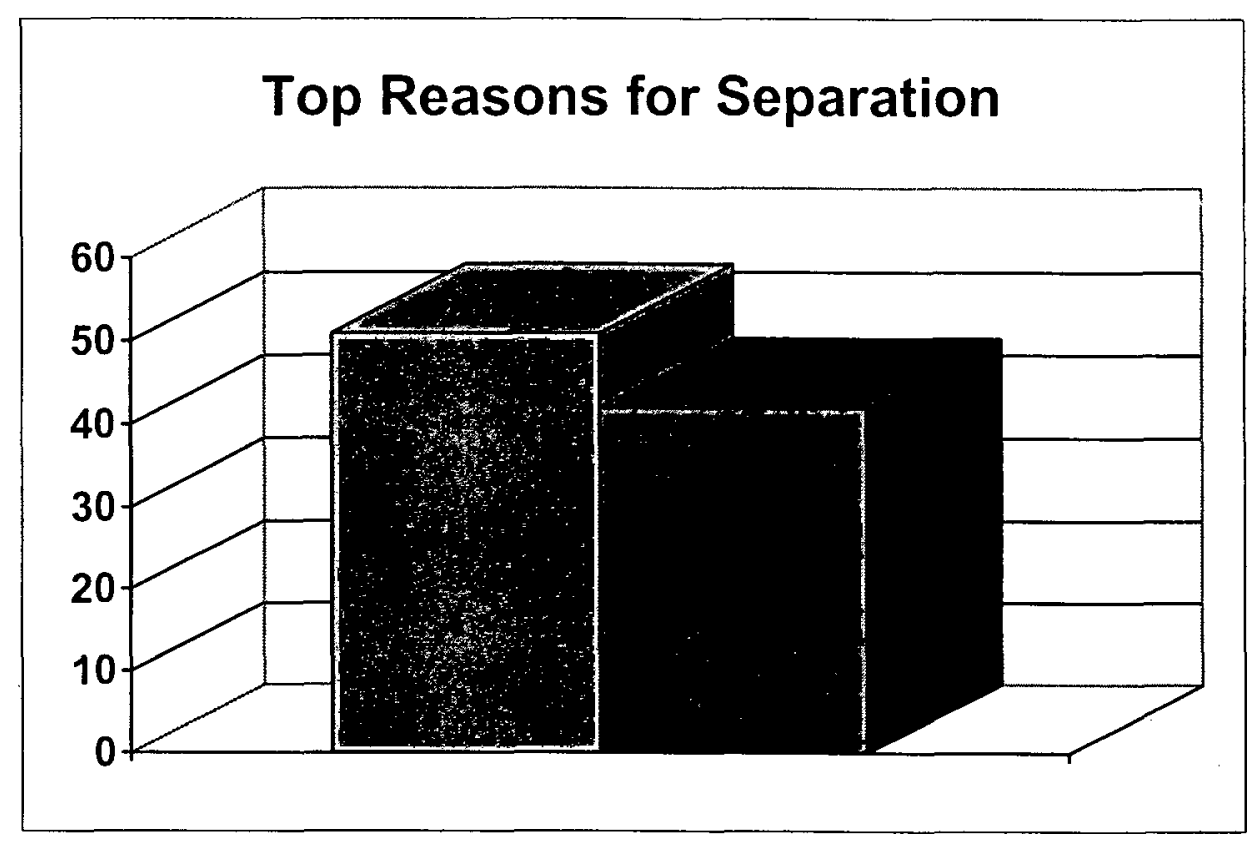

Fig. 3. Top reasons for separation. Source: survey responses.

Although many subjects believe that temporary separation is not the key for resolving relational or economic problems (55 percent), many of them would accept the solution of separation for a short time ( 20 percent) in order to obtain money for their family. 


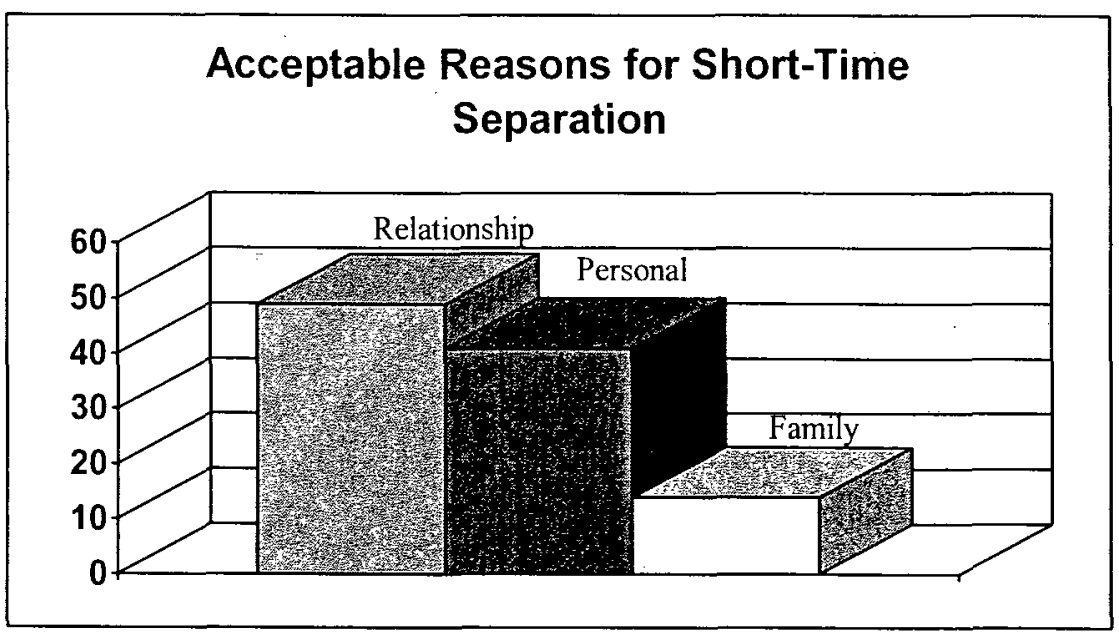

Fig. 4. Acceptable reasons for short-term separation. Source: Survey responses.

Another paradox indicated by the survey is that despite the fact that 70 percent of our respondents would not consider separation a good solution for the family, 47 percent admit that there is some benefit in working abroad in regards to the financial opportunities for the family. This paradox reveals the although there is a commonly agreed-upon desire of the couples to be together, the financial crisis that strikes families makes it impossible to provide a decent life for couples, and pushes the families to make the decision to be separated for a while. However, despite the temporary financial gains, the majority of our respondents would not recommend family separation to other couples (see figure 4). 


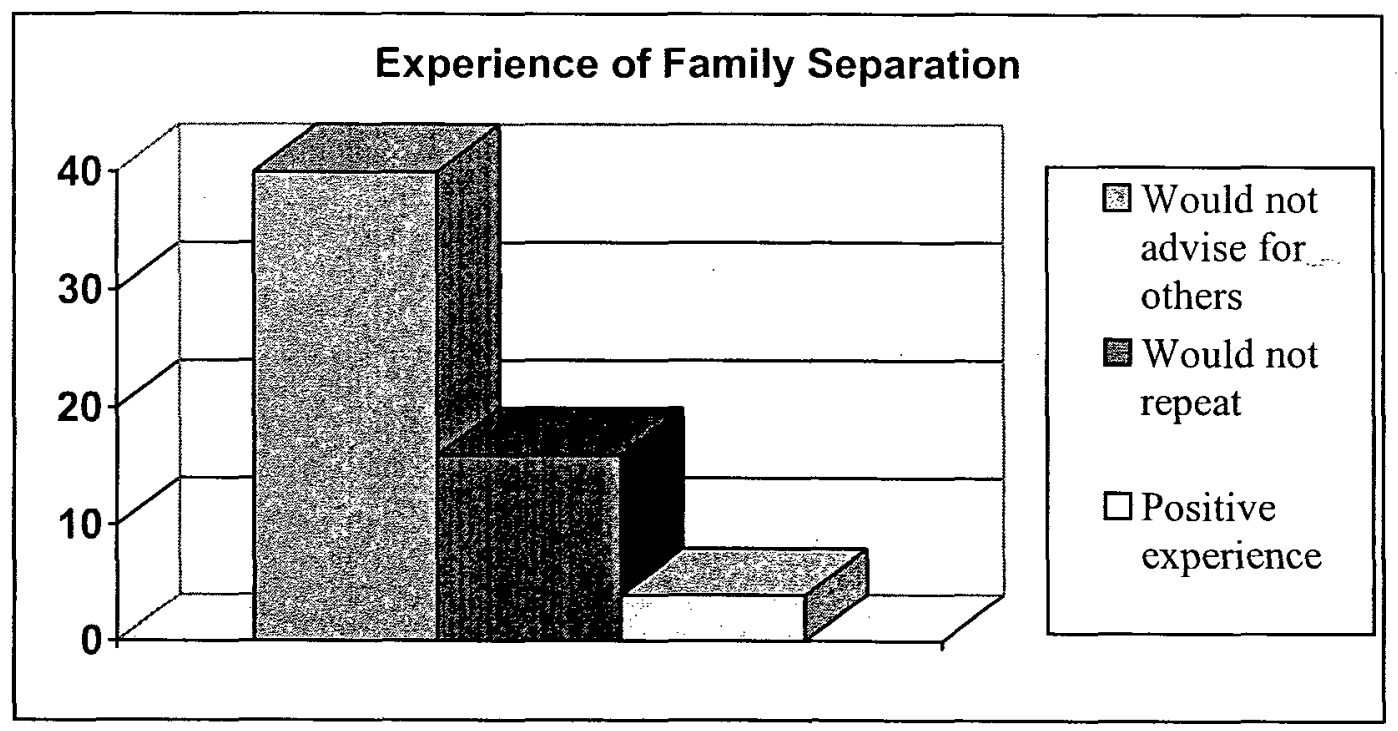

Fig. 5. Experience of family separation. Source: Survey responses.

Seventy-four percent of subjects realize that separation of spouses leads to a weakening of the relationship between spouses while 31 percent see it as more serious, eventually leading to infidelity. An additional consequence of separation in the short and long term is a weakened relationship with children (44 percent). In some cases when fathers returned home after two to three years of work in a foreign country, their children failed to recognize their authority and treated them as strangers (fig. 5).

Thirty-one percent of our respondents consider separation a potential and real danger for the emotional health of the couple. Infidelity of one of the partners could cause irreparable damage to the family. Too often, the price paid for a fist-full of dollars or euros, is too high - the loss of the positive relationships between spouses and/or between parents and children. 


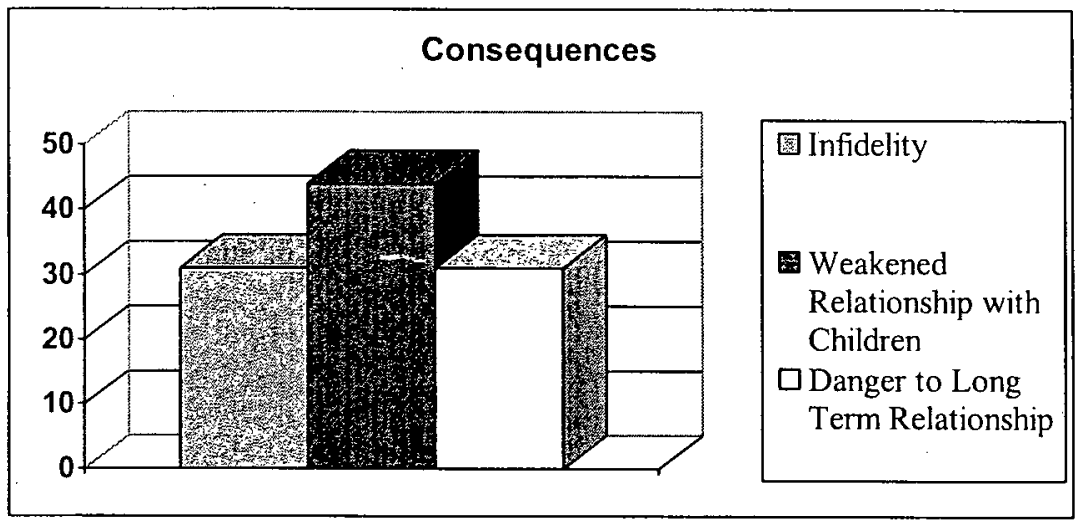

Fig. 6. Consequences of couple separation on the family. Source: Survey responses.

Church's Response to Temporary Family Separation

Romanian Seventh-day Adventists believe in the value of the family and consider the church a shelter where they can find comfort and emotional support in times of trouble. About a third of them ( 30 percent) believe that the church rejects the idea of separation and promotes unity and love between spouses. A greater number (45 percent) admits that the church accepts separation and divorce in cases of infidelity (adultery). Nineteen percent (19 percent) view the church as a place where individuals can find emotional support in time of discomfort. Romanian society was built on the values of the family, and according to tradition the family was the center of life. If we add to this the scriptural teaching, the goal of God for the family, we discover the reason that Romanian Adventists consider church as a place where they can find emotional and mental support. For almost fifty years, Communism oppressed every individual who believed in God, but the church was a fortress, a place where the believers expressed and increased their faith in God. The church was almost the only expression of opposition to the totalitarian regime. Moreover, the church was the only place where the wounds of the heart were 
treated and healed. If we have just nineteen percent of respondents who believe that the church is like a hospital for souls, it is due to the lack of involvement of the church in their problems of separation.

On the issue of separation for economic reasons, about one-quarter of the respondents considered the church to be against the idea of separation (23 percent) and the same number viewed the church as an institution that promotes free choice on this issue. In order to understand this aspect, consider the two tendencies (views) in the Adventist Church in regards to the practice of religion: conservative and liberal. Each faction's proponents bring proofs from the Bible to justify and promote their views. We therefore have to keep in mind the impact of personal views on religious practices with the results of the survey. There is a great potential for biased responses reflecting personal views rather than factual reality.

The pastor is perceived by almost a quarter of respondents as being against family separation (22 percent). Romanian Adventist Church members view their pastors as defenders of the unity and fidelity of the family. When separation occurs, only 23 percent of the subjects report a direct involvement of their pastors in their problems, through personal visitation and prayer. Communication by mail, e-mail, or phone between pastor and those who work abroad is almost non-existent (about 5 percent report such communication). Pastoral support appears to end once the individual travels outside the pastoral jurisdiction. This can be explained by the overloading of pastors, of having too many tasks to fulfill, too many churches to minister to, or too many families in his district that are affected by family separation. Consequently, he doesn't have enough time to keep in touch with those who work abroad. This problem could be resolved if the 
vision of the church would be changed. Instead of "one hero" (the pastor) and "tens or hundreds of fans" (the members), every member should be a "pastor" with a responsibility in the church.

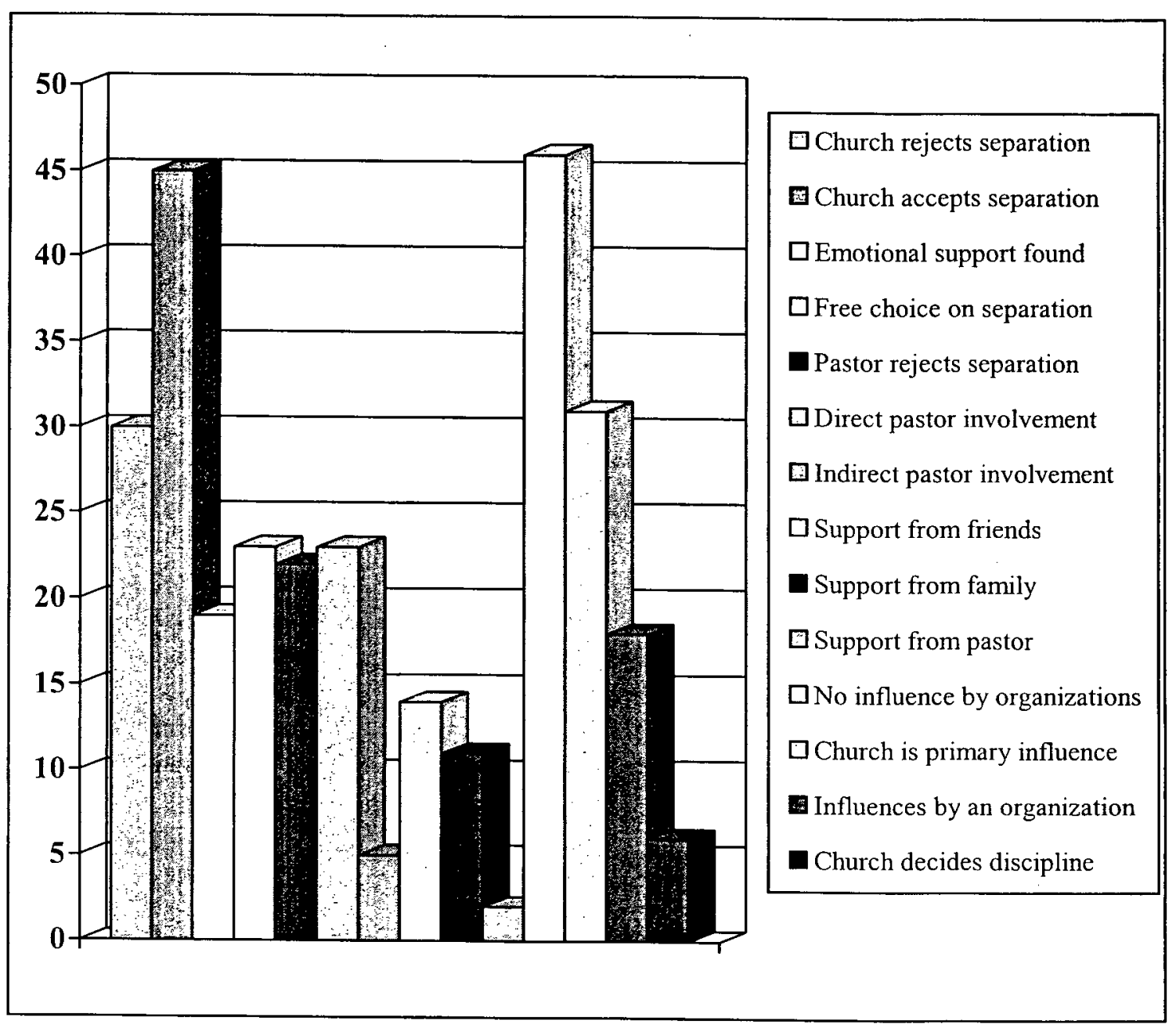

Fig. 7. Views on separation in the faith community. 
Fourteen percent of the respondents report that friends from the church and family members (11 percent) offer the primary emotional, spiritual, and material support for those affected by separation. The pastor comes last ( 2 percent) among all acknowledged supporters. The reasons for such a lack of involvement by the pastor were presented above. We can add that the family members and friends, by their relationship with those affected by separation, can understand and offer emotional and spiritual support to them.

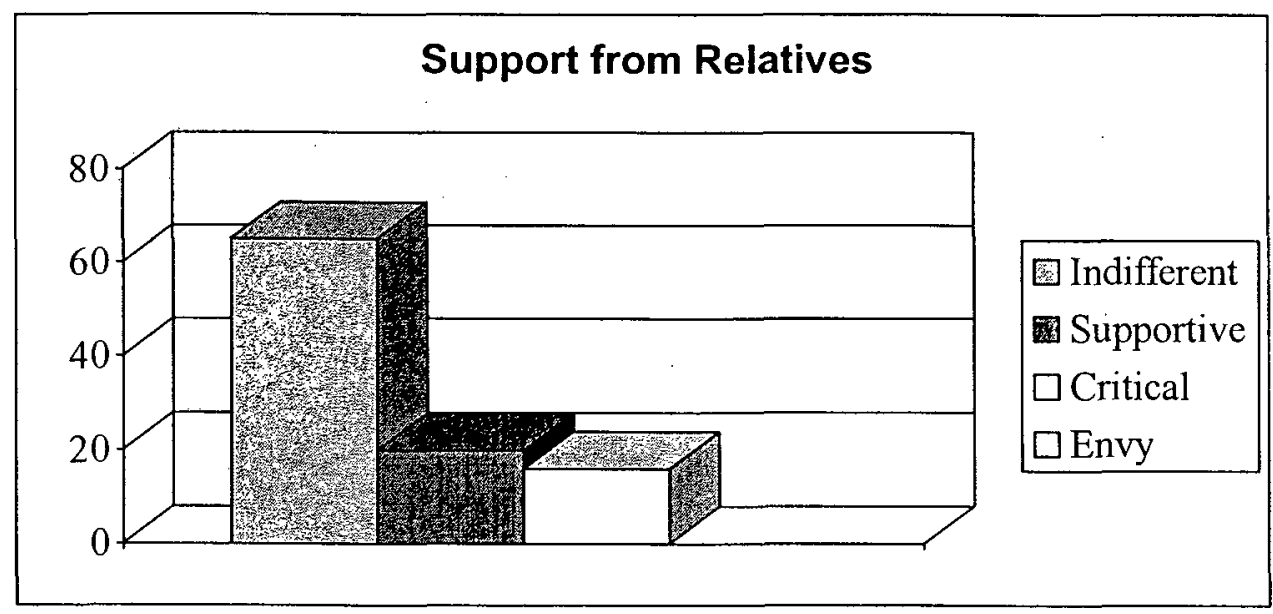

Fig. 8. Support provided by relatives to families going through couple separation.

The reactions of the church members regarding the issue of separation include indifferent (12 percent), supportive (9 percent), with some individuals criticizing ( 9 percent) or envying ( 2 percent) those who are separated from their spouses. Such attitudes must be seen in the light of over forty-five years of Communist indoctrination in Romania that included training communities to spy on one another, to develop envious attitudes toward one another, especially towards those individuals who 
had a tendency to gain wealth. If an equal percentage of supportive and critical people were looked at, there would be a realization that some people take on a judgmental role in the church as guided by the saying: "We help, and therefore we can judge!"

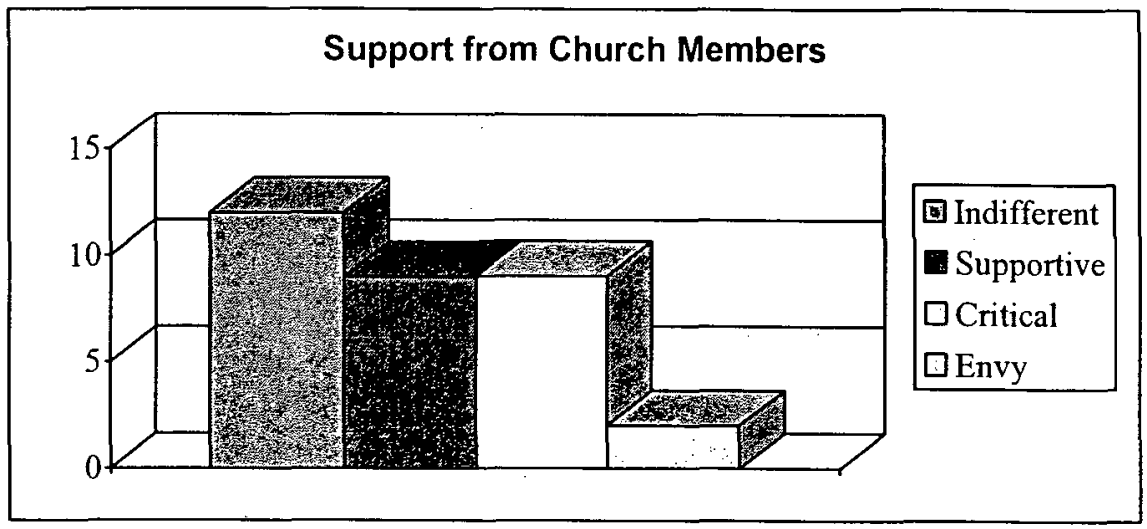

Fig. 9. Support provided by the church to families going through couple separation.

The individuals affected by separation look for support and comfort to the church, the pastor, and friends from the church and the members of their family. Many times they find the support they are looking for, as admitted by almost half of our respondents (41 percent). Beside the burden of the separation on the spouses for a longer or a shorter period of time, ten percent report that they have to face the challenge of some of the members who judge or misunderstand them.

In the view of about a third of the respondents, the church remains the principal resource for moral, emotional, and relational support (31 percent). This perception of the church is understandable in light of the fact that the church through its departments is created to be a shelter and a spiritual and emotional support for its members. In addition 
to preaching the Gospel, spiritual and emotional support is a critical element of the church's role. Moreover, other relatively new organizations, have not earned the trust of members yet. The church by tradition remains the main source for comfort and encouragement.

Community's Response to Temporary Family Separation

Depending upon the nature of their relationships, neighbors have a supportive attitude (11 percent) or an indifferent one (14 percent). However, most of them have a critical attitude toward those who separated ( 20 percent) for the same reasons that were presented above. It is amazing to note the number of community members with envious (11 percent) or antagonistic (12 percent) attitudes. Some of these attitudes have their root in jealousy, others in the lack of opportunity (financial or physical) for the envious person to travel abroad. The same consequences of the Communist indoctrination can be seen in this aspect. The imposed notion of "living together and working together" has distorted the meaning of community. According to the Communist ideology, the members of the community should be equal and all differences should be eliminated. 


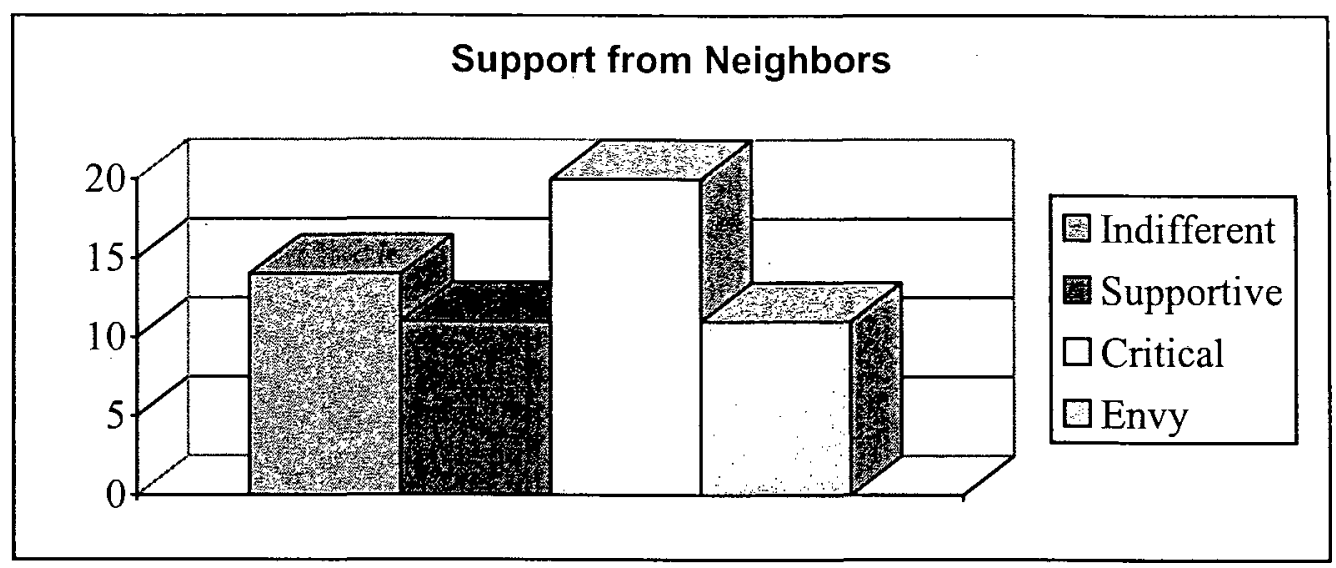

Fig. 10. Support provided by neighbors to families going through couple separation.

Friends of separating couples (24 percent) are more supportive than relatives (20 percent). Similar levels of criticism are identified from fellow workers (16 percent) and relatives (16 percent). However, relatives tend to be primarily indifferent ( 65 percent) when compared with friends ( 9 percent) and fellow workers (11 percent).

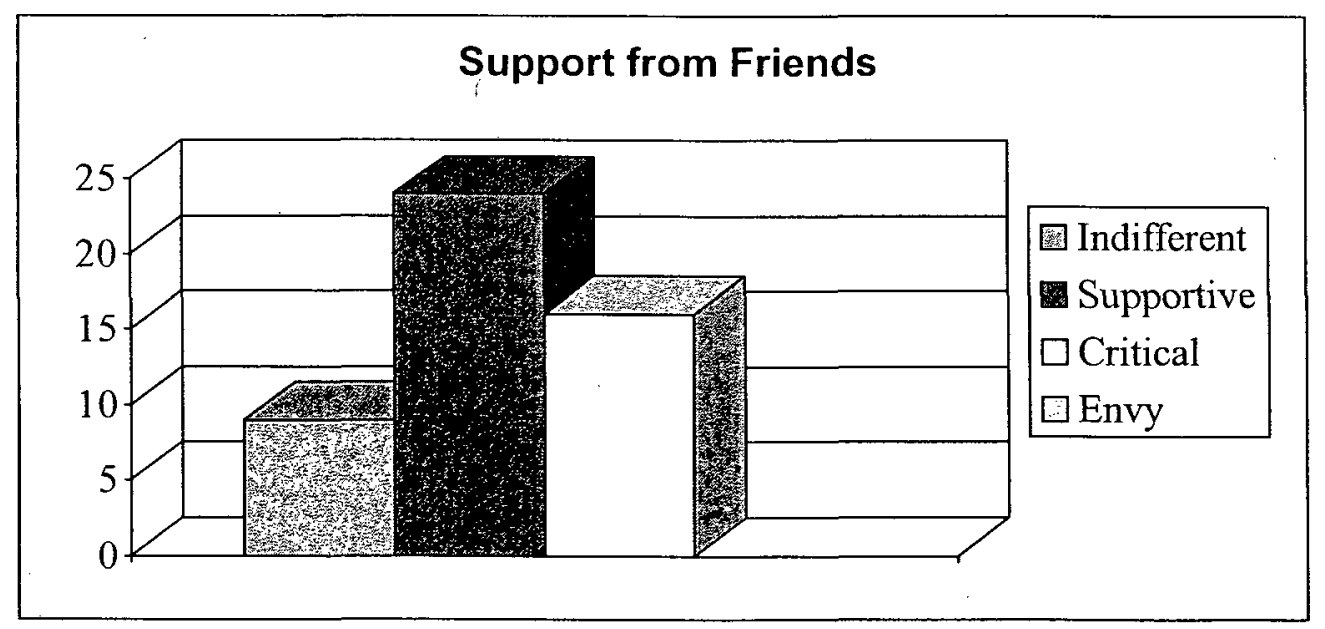

Fig. 11. Support provided by friends to families going through couple separation. 
The overall perception on the effectiveness of other organizations (humanitarian organizations, special organizations from the town hall) in addressing issues related to couples' separation indicates low effectiveness, with almost half of the subjects (46 percent) not believing in these other organizations. They are either mistrusted or considered as non-existent in Romanian society. Such perceptions may be attributed to the large number of Romanian people facing poverty or separation for economic reasons, and/or because of a lack of funding for the organizations. Due to the centralized Socialist system under which there is no private sector, and all social issues are dealt with by the state, it is not hard to understand why humanitarian organizations can't find a rightful place in the life of the community. About half of the subjects prefer not appeal to other organizations (46 percent) while only 18 percent are willing to seek assistance.

Those relatives that are not indifferent are perceived as more likely to offer spiritual and emotional support (17 percent) than children (15 percent) or the church ( 8 percent).

The survey indicates that church members are ready to help others confronted with the problem of separation. About 40 percent visited someone separate from a spouse and more than half ( 57 percent) prayed for them. The survey also revealed that a small number of respondents consider an invitation to dinner (14 percent) or to church (13 percent) as a good opportunity to support individuals encountering the difficulties of separation. 


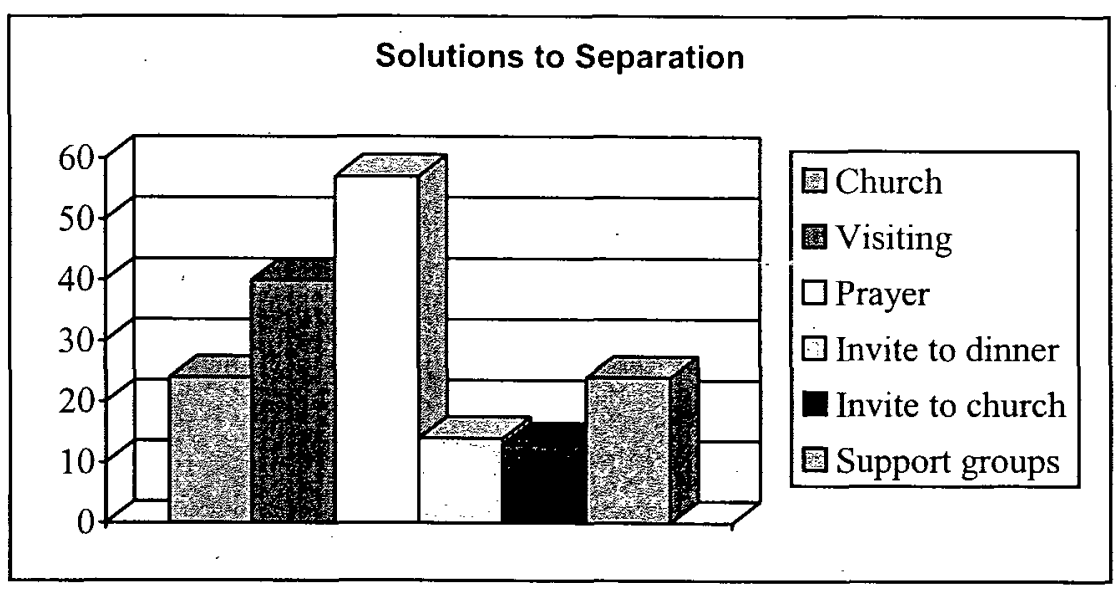

Fig. 12. Current Responses to Separation

\section{Perspectives on Potential Solutions to Problems}

As could be expected, the respondents ( 74 percent) turned to the church to find solutions for problems arising from separation for economic reasons. They don't expect solutions from the government, friends or relatives, but from the church. This shows the level of trust that they have in the church and its capacity to find solutions not only for the spiritual life, but for material life, as well. Another 24 percent of the subjects would attend support groups developed by or in the church. In a country confronted with a low standard of living, some individuals expect the church to meet both their spiritual and material needs. Families with many children and a low income look for financial support from the church. Others look to the church as a place where their emotional and spiritual needs are met. Especially in the big churches where the different departments are well organized, the church can meet the spiritual and material needs of its members. Unfortunately, not many churches have support groups because their efforts are on meeting material needs of their members and communities. 
What are the pastors doing and how does this compare with expectations? After the Revolution in 1989 when Communism was abolished, a new era opened for the church. With a new freedom to preach the Gospel the church focused on public evangelization and many other evangelistic projects in order to reach out to the secular people. All pastors were encouraged to be involved in evangelistic projects and to use all their resources to bring people to Jesus. Due to this important emphasis and many other projects received from the Euro-Africa Division, the Romanian Union, the Conferences, and all the pastors were loaded with a lot of assignments.

On the scale of priorities, the care for families confronted with separation received little attention. Only when the separation resulted in an adulterous relationship, did the pastor and the board put that case on the agenda of the church. Many of the respondents ( 74 percent) believe that the pastor could provide more support during the crisis of separation. The pastor, with the assistance of the church board, should identify strategies for offering support in instances of separation.

Another solution, recommended by 24 percent, would be for the pastor to keep in touch by mail, e-mail, or phone with those who work abroad. This type of support is very important, because knowing that representatives of the church care for them will help the separated workers to keep in touch with their church and family.

Interestingly, 6 percent believe that the duty of the pastor and the church is to decide what disciplinary measures can be used against families confronted with the problem of separation. In other words, these respondents believe that the church should be a punitive organization that shows its love for members by punishing them. 
Twenty-eight percent indicated that they expect the pastor to preach against the idea of separation and to spend more time counseling those affected by separation.

\section{Perspectives of Pastors and Leaders of the Church}

In order to get an in-depth understanding of the church response to family separation, we conducted two focus groups with pastors and leaders of the church. The findings for the focus groups are nearly identical, despite the fact that the respondents represent different areas of the country, and different levels of administration. This demonstrates the consistency of opinions on the issue of separation for economic reasons. Following are the main themes identified during the qualitative analysis on the two focus groups.

\section{Ideal Versus Reality within the Christian Family}

Family and Sabbath-two institutions created by God to bring peace, fulfillment and happiness to the human being; same importance is given to the integrity of both. Lack of communication is a primary factor in family dysfunction.

Communism created a false ideal for the family, denying the existence of God, the Author and Promoter of the family.

\section{Current Problems for the Christian Family and Methods of Addressing These Problems}

1. The post-revolution pressure of society upon the classical shape of the family

2. The conflict between the post-modern, western family model, and the traditional Romanian view of families 
3. Migration toward urban areas for a better and easier life

4. Lack of money versus desire to have a high standard of living

5. Economic crash-from the rates $\$ 1=35$ lei (1987) to $\$ 1=34.250$ lei (2002)

6. Besides economic problems, many families are confronted with an absurd sense of competing with others, trying to maintain a comparative lifestyle with their rich neighbors

\section{Separation As a Solution or As an Aggravating Factor}

Separation is accepted only in families where violence is present. In other cases, it compounds relational difficulties.

Separation creates a false image of a viable and acceptable solution for all those who are in trouble.

The financial pressure that motivates individuals to go abroad looking for wellpaid jobs is created by the gap between western standards and the limited income potential of Romanians.

The exception to the general trend of separation exists in the Banat Conference, (located in the western part of Romania, at the border with former Yugoslavia), where people are not tempted to go abroad because geographically, the region is closer to the West and many foreign companies invest heavily in this area. Even under the Communist regime, this area had more freedom than other parts of the country. Among church members, it is not the poor class that goes abroad seeking well-paid positions (they do not have enough money to follow their dreams). Instead, people from the middle class are more likely to seek such opportunities. 
Not only the immediate family is affected by their members that leave the country for economic reasons, but the church is, also. With pastors being among some of the ones leaving the country, the church is losing its leaders, becoming poorer in leadership capacity. The upside of this problem is that by leaving Romania, old leaders make room for a new generation of young leaders, although there are some young pastors that eventually consider immigrating to other countries as well.

One response of the Romanian Union to the emerging problem of family separation within the church is the official declaration regarding emigration and the role of the pastors in counseling those affected by separation (see appendix C).

\section{The Role of the Church in Assisting the Family with Problems}

When talking about the church's role in assisting families confronted with temporary separation due to economic reasons, the following aspects were mentioned: (1) The church lacks special programs for families confronted with separation, (2) in those churches where local leadership is not well-organized, no one has an accurate record of missing members, and (3) economically speaking, the church does not have adequate resources and experience to face these kinds of problems-this is not her mission.

\section{The Role of the Pastor}

There is a perceived lack of competence in counseling for families confronted with separation. 
The pastor prefers to resort to disciplinary actions, by applying the regulations prescribed in the Church Manual instead of exploring each individual case and attempting personalized solutions.

The pastor has both the ability and the call to present an accurate image of the Western countries whose realities do not necessarily correspond to the immediate expectations of the ones that intend to immigrate.

Pastors who are sensitive to social or interpersonal problems are able to assist families in a personal manner.

\section{Potential Solutions in the Church and Community}

The church could mobilize the corporate sector, asking them to provide expertise and to initiate projects to develop small businesses in different areas of Romania, that will lead to economic development in the country, increasing local employment options, and decreasing the number of people that will search for employment abroad.

The Women's Ministry in Romania is in the process of developing a seminar for the families affected by separation.

\section{The Attitude of the Church Regarding Separation}

The separation of spouses is not widely condemned, considering the fact that it is an attempt to solve the larger issue of poverty.

Pastors do not appear significantly concerned about the phenomenon of temporary family separation. One reason for this lack of concern might be their own bias about the matter, as there are cases when the pastors' wives pursue employment in other countries. 
The pastors, therefore, have little influence on others families experiencing similar situations.

To address this issue among pastors' families, the Romanian Union adopted a regulation allowing pastors to take a month's leave of absence without pay every three

years to work abroad. The effect of this regulation was that almost every pastor now has a good car-this being a priority for increasing the effectiveness of their work, with churches sometimes located at wide distances from one another.

There are two aspects of the problem of separation for economic reasons: First, there is a concern that members leave the church, weakening its missionary potential. Second, there is a belief that members who work abroad will better sustain the church financially.

As long as the economic situation in Romania remains in its present condition, it is risky and even impossible to initiate a strategy to prevent individuals from leaving and pursuing employment in other countries.

\section{Discussion on Findings}

The Romanian family is under financial pressure due to many economic factors that affect Romanian society. The transition from a centralized economy, under Communism, in which everything was programmed and decided by the Communist leaders to a decentralized economy in which the most important principle is the relationship between supply and demand, created a gap that affected the whole nation. Many families were affected financially by the lack of work, so Romanian people looked more and more to the Western countries as a solution for providing money for their families. 
The purpose of this research was to identify the main factors leading to family separation in Seventh-day Adventist faith communities in Romania, and to explore the ways in which the church responds to this matter. Furthermore, it is our desire to identify potential strategies that will lead to a better response of the church, and will also support the church in its endeavor to work with member families. A secondary objective was to determine whether the church is able and prepared to face such crises in the life of the family. The findings will be used to assist the Romanian Union, Conferences, pastors, and local churches in designing strategies for approaching current problems in the church, family separation being just one of them.

From the point of view of our respondents, the main factor leading to family separation in Romania is the economic aspect that confronts the post-Communism society not only in Romania but also almost all countries in the ex-Communist block. The transition from a centralized economy practiced under the Communist regime to a market economy based on demand and offer, many people lost their jobs. In order to offer financial support to their families, more and more people found a solution working legally or illegally abroad. Even though many of those confronted with separation due to economic reasons discovered that the experience of separation was not the best solution for their financial crisis, they chose it in order to offer a decent life for their families and to provide good education to their children.

Sometimes those who decided to separate from their spouses for a limited time, had to pay an unpredictable price, bringing more troubles than blessings to their families. Separation often resulted in the alienation of children, the emotional distancing of spouses, in worst cases leading to adultery or divorce. In spite of these risks, more and 
more members of the church choose to add to the numbers of those who leave their families pursuing employment in other countries.

Unfortunately, the church is not prepared to face such a phenomenon in spite of the many years that have passed since this process started. Both pastors and churches admit the seriousness of this phenomenon, realizing that something should be done in order to stop the avalanche of so many tragedies that occur. They bewail this current reality faced by many families in Romania; however, there are no church-wide practical solutions so far. The church declares its powerlessness on the one hand to stop the process of family separation due to economic reasons, and on the other hand to create a viable solution that would meet the needs of its members confronted with poverty. The years of imposed "equality" during the Communist regime affected the church, fostering a spirit of criticism and increased individualism that makes it more difficult to understand and meet the real needs of church members, beyond spiritual issues. However, while the church as an institution might fail to provide an effective response to critical situations, the great majority of the members confronted by separation still consider their faith communities as the best place where they can find spiritual and emotional comfort and, at times, even some material help.

Speaking about the reaction of the community or friends and relatives of those confronted with separation, we can divide them in three groups:

1. The supporters' group which offer their encouragement in words and attitude. They pray for families going through temporary separation, talk with them, and invite them for fellowship in their family or in the church. Instead of judging them, they 
sympathize with them trying to walk in their shoes. Due to this group many families survive and maintain a healthy relationship during times of crisis.

2. The indifferent group represented by those who are indifferent to the problems of those confronted with family separation. They have their own problems. They neither blame nor encourage the separation.

3. The critics' group who, either due to jealousy or under the pretense of false caring, criticize and blame those families who took the decision to separate for economic reason. They are inclined to support the church in taking disciplinary measures against such individuals/families.

The community is not very effective in helping families in poverty, as poverty rates are on the rise, and the economy in Romania is still gravely affected by the transition to a market economy, combined with a lack of political and social understanding of democracy. Even though every city hall is affiliated with different governmental and non-profit organizations, there is an increased distrust of the population in public figures, due to the perceived lack of implication in real life.

People appear to still trust the church and the pastor, and in case of family separation, they ask for assistance and counseling. This attitude creates more obligations and responsibility from the leadership of the church at all levels.

The focus group participants reported that the discussion on family separation and the church's response was like a wake-up call for the Romanian church at every level. The Family Life Director at the Romanian Union sees the church as doing too little to monitor and assist these families. Other participants consider that by offering spiritual and emotional assistance, and some material help, the church can help many families to 
discover new resources of love and commitment in the relationship between spouses, thus avoiding separation. In regards to the lack of involvement of the church in critical family situations, most participants refer to the individuals' freedom of choice.

\section{Conclusions}

All participants had a responsible approach to the topic that emphasized the importance of balance in making the decision to work abroad. They admitted that this is not the best choice, but due to the decline of economy in Romanian society, sometimes it is a temporary solution for survival.

From the Moldavia Conference focus group, an experience was presented whereby some pastors took the initiative to implement projects to help families to improve their financial conditions, and as a consequence to stay together. By following such a plan, it is not necessary for one spouse in a marriage to go abroad for work. With ingenuity and perseverance, solutions may be found. With a modest investment, many people can earn enough money to live a decent life, thereby avoiding the risk of deteriorating relationships that arise when a spouse goes abroad. Below are some specific examples:

1. One of the pastors was raised in a village where almost every inhabitant had a green house to cultivate and sell vegetables such as tomatoes, cucumbers, onion, carrots, and eggplants. The pastor gathered members from his church together, and taught them how to raise money using a garden. From that year, the Adventists knew what prosperity was. Every Romanian pastor could be a teacher for his members, helping them to cultivate gardens in an effective manner. 
2. Another pastor from the same Conference had been a skilled apiarist before being a pastor. He helped his members by offering them practical lessons of bee keeping. He also supervised his members in their activities as they put this new knowledge into practice.

3. One of the pastors who had many gypsies in his church taught them how to start a small business. The poverty of this social ethnic group is well known. Most of them live at the limits of survival. The pastor asked them to combine mud with straw, and to form the mud-straw combination into a shape. After three days they discovered that they possessed good bricks, which they sold.

4. Another practical experience arose when a pastor taught his members the benefit of mini-workshops, and helped them to establish these workshops by finding sponsorship from various donors.

It would be great if pastors would search and discover some members of our churches with special skills in areas such as construction, tailoring, cooking, painting, gardening, apiculture, and so on. These skillful members could present practical lessons for those who are in a financial crisis and want to do something for survival. 


\section{CHAPTER VI}

\section{STRENGTHENING FAMILY: CHRISTIAN APPROACHES TO FAMILY ISSUES ASSOCIATED WITH TEMPORARY SEPARATION}

"Across the country, more than 2 million children are being raised by relatives because their parents can't provide adequate care. The majority of these kids, according to the Children of Alcoholics Foundation, are there because of a parent's alcohol or drug problem."

"Sometimes relationships are like flowers: They are beautiful when they bloom but they don't always last very long."2

"Sometimes, the victim will wind up in the hospital, as did a Lambertville woman who was chocked and beaten so severely by her husband that she miscarried their unborn baby. (Kramer, Victim, 1998) She was only one of the approximately 1.4 million people who require medical treatments each year for injuries caused by domestic violence. (Rand 1997."3

'Caitlin Johnson, Strengthening Families Ties, http://www.connectforkids .org/node/375 (June 30. 2006).

${ }^{2}$ Frank M. Dattilio, Case Studies in Couple and Family Therapy (New York, NY: Guilford Press, 1998), 10.

${ }^{3}$ Sue W. Kramer, Domestic Violence-The Circle Called Love (Philadeplhia, PA: Xlibris Corporation, 2000), 15. 
If we consider just these three aspects presented above, we can have a picture of the problems that affect negatively our families' today. This is a clear sign that our society should do something to improve and strengthen relationship in family as a sine qua non condition for a strong and healthy community.

Following the relationship with God nothing is more important than the relationship with your family. Due to so many cultural and social changes that occurred during the last decades, the family was undergoing dramatic changes that significantly affected. Being confronted with difficulties, the easiest way is to give up, to forget about the vow "together for better or for worse", and to look for a better partner. According to the US Census Bureau, 43 percent of first marriages end in separation or divorce within 15 years." Of course this percentage could be different from state to another state. However, despite percentage differences, divorce appears to be the most common solution to family problems.

Another solution could be to have the courage to admit that there is not any-free family, and to continue to work on the relationship we committed to through marriage. At the same time, it is a must to keep in mind that the goal of every family shouldn't be just to survive in a marital relationship, but to be happy.

Froma Walsh, co-director of the Center for Family Health at the University of Chicago, refers to the starting point in coping with challenges that confront the family. She writes, "At a time of widespread concern about family breakdown, it is more

\footnotetext{
${ }^{1}$ U.S. Census Bureau, "Martial Status and Living Arrangements, March 1998 (Update)," http://www.gendercenter.org/mdr.htm (June 30, 2006).
} 
important than ever to identify key process that can enable family members to weather stresses and rebound strengthened as a family unit."1

The process of strengthening family is not an easy one, neither does it provide an quick solution. Every member of the family, spouses and children alike, have a role in this process. Most couples who are pursuing professional counseling "complain of a lack of understanding and love shown by the other mate." ${ }^{2}$ In the rainbow of ingredients for a happy relationship that leads to a strong family, understanding and love are some of the most important. For this reason it is worthy to invest more time and energy in order to develop a real personal strategy for strengthening relationships between spouses.

The consequences of a good or bad relationship in the family pass beyond the parents and they have a strong impact on children. Because "No matter how dysfunctional the family, children want to be loved and accepted by their parents."

Is family life today different than one hundred or even ten years ago? In order to find out the right factors to strengthen today family, first we must have a better understanding of causes that produce discomfort and affect negatively the relationships in the family.

Orthner (1998) stresses the changes, and also some of the factors that challenge today's family, saying:

It is almost easier to describe today's families as a process than as a status: Family life has become so dynamic, so full of unexpected twists and turns, those scholarly 1998), 26.

${ }^{1}$ Froma Walsh, Strengthening Family Resilience (New York: The Guilfor Press,

${ }^{2}$ Richard B. Stuart, Families in Crisis, eds. Paul \& Lois Glasser (New York: Harper \& Row, Publishers, 1970), 172.

${ }^{3}$ Lisa Kaplan and Judith L.Girard, Strengthening High-Risk Families (New York, NY: Macmillan, 1994), 13. 
observers, service providers, and the public at large are having trouble just defining the family, let alone capturing its needs or trying to meet them. Debates abound around core issues of the family. What are the boundaries of the family? Who is in and who is out? When does a new family start, at cohabitation, at marriage, at parenthood? When does it end, at separation, at divorce, at remarriage, at death? And how does it normally progress, with or without parenthood or with or without living together?

In this context it is not difficult to realize that today's family is more fragile, and the concept of roles and rules within the home are not the same as they were for the previous generations. And although today's families have more comfort, advanced technology, achievements and substance, these appear to sometime be in the detriment of a quality relationship between spouses and between parents and children. The more time is spent to earn money for the achieving and maintaining a superior life standard, the less remains to be invested in the immediate relationships.

\section{Practical Steps in Strengthening Families: A Christian Approach}

There are many important issues that confront us today. We can talk about a cleaner environment, terrorism, and more jobs for us and our children. When we consider the opinion of Americans on prioritizing the issues that need to be addressed, having better family life seems to top the list: "A new poll finds that most Americans believe that strengthening families is a greater priority than having a cleaner environment or increasing job opportunities. The poll, released August 30 by the year-old Alliance for Marriage, found that 59 percent of Americans view the state of the family as "not very

'Dennis K Orthner, "Strengthening Today's Families," Parks \& Recreation 33 no. 3 (March 1998): 87. 
strong" or "weak and losing ground," compared to 40 percent who think it is "reasonably strong" or "very strong and growing."1

The size of the family is not such an important factor when it comes to strengthening families: It could be a nuclear or extended family, we can talk about singleparent families, as well as reconstituted families. Strong, healthy relationships that bound together the members of the family can offer emotional, spiritual and physical support to each family member when confronted with a crisis. It is the sense of belonging to a loving family what keeps us going.

There is no magic formula for a happy marriage; at the same time, some keyfactors can perform miracles if they are developed in relationship of the family. "In order for a crisis to be solved, it must first be identified." From the multitude of them, we will presented just a few, due to the limitation of the dissertation. The order of their presentation does not necessarily reflect their importance.

1. Communication. There are studies that analyze the importance of open communication for a healthy and fulfilling family life. ${ }^{3}$ A positive communication is a sine qua non condition for the unity and happiness. I called it "positive communication," understanding the quality of changing the information, ideas and feeling. In his book, Families (1983), David H Olson, defines positive communication as a "level of comfort

'Family Public Opinion, "Strengthening Families a Priority for Americans," The Christian Century 117 (September 2000), 948.

${ }^{2}$ Mollie Stevens Smart \& Laura Stevens Smart, Families-Developing Relationships (New York, NY: Macmillan, 1976), 413.

${ }^{3}$ See Family Relations 42, no. 1 (January 1993): 38-45. 
felt by both partners in being able to share important emotions and beliefs with each other"

James Dobson also refers to a positive communication, when he answers to one client's complaints, "Try not to resort to what I have called the "bludgeoning technique," which includes and endless barrage of nagging, pleading, scolding, complaining, and accusing. ... Instead of yelling at him, you should look for opportunities to teach your husband during moments when he is most likely to be listening. That instruction requires the proper timing, setting, and manner to be effective."2

2. Commitment to family. Many partners forget too soon about their pledge the made in front of God and many other people. The sense of commitment loses some of its value and without new energies and new infusion of love and faithfulness, life gets bored and monotonous. From this moment to the coldness of relationship there is not more than one step. Dr Dobson applies the law of entropy to the family experience. "The naturally tendency of everything in the universe is to move from order to disorder. We are, in a manner of speaking, in a dying universe where everything that is not specifically being protected and upgraded is in a downward spiral. The principle that governs this drift from order to disorder might be called "the law of disintegration.

... The only way to postpone or temporarily combat its influences is to invest creative energy and intelligent design into that which is to be preserved."3

${ }^{1}$ David H. Olson, Families-What Make Them Work (Beverly Hills, CA: Sage Publication, 1983), 104.

${ }^{2}$ James Dobson, Complete Marriage and Family (Wheaton, IL: Tyndale House Publishers, 2000), 311-312.

${ }^{3}$ Ibid., 328. 
For different reasons, there are events in life that keep the family members separated for a long or short time. The principle of commitment to family is maybe the strongest pillar of the home. Not only should the wedding certificate be the link that keeps together spouses, but also the sense of commitment, the promise to be faithful to the partner until death.

3. Forgiveness. In our human nature we don't have propensities to love, to forgive, to forget. These qualities can be developed only if the foundation of our relationship with people around us is nourished from above. The Christian writer, Lewis Smedes (1996) writes about the uniqueness of forgiving in the human experience. "When you forgive the person who hurt you deeply and unfairly, you perform a miracle that has no equal. Nothing else is the same.... Forgiving has its own feel and its own color and its own climax, different from any other creative act in the repertoire of human relationships. Once we have forgiven, however, we get a new freedom to forget. This time forgetting is a sign of health; it is not a trick to avoid spiritual surgery. We can forget because we have been healed." "Nobody is perfect. For this reason the only way to deal with our imperfection in family relationship is to offer and to receive forgiveness.

In our context, forgiveness is primarily referring to the idea of unfaithfulness of one spouse, or clearer-an extramarital affair. Too often, during extended periods of separation of the spouses, one or both of them get involved in other relationships in their close proximity, commit adultery. The question is, can a marriage survive an affair? Here are some practical recommendations that could strengthen a family undergoing such crisis:

\footnotetext{
${ }^{1}$ Lewis B. Smedes, Forgive \& Forget (San Francisco: Harper Collins Publisher,
} 1996), 38-39. 
A. Never believe whatever you learn, especially when it is about your husband (wife). There are some people who, out of jealousy, or envy, or for no reason at all, invent bad news about others to discredit or blame them. Marriage relationships should be based on reciprocal trust, and this feeling should preclude any other quick judgment or rushed decisions.

B. Pray. When people cannot be completely trusted, God is always trustworthy and ready to help you think through your problems. He encourages us to bring to Him all our troubles.

C. It is often useful to share some of your fears with someone you trust (pastor, parents or close friends). Keeping just in your mind such a thought it will give you sleeplessness and interior discomfort. Talk with someone about it.

D. If what you learn about your spouse is true, look for an opportunity to discuss the matter with them. When serious issues occur that affect the marital relationships, it is often useful to discuss these issues openly and be willing to work together on finding the best solution.

E. Forgive and ask for forgiveness. One important issue to learn is that forgiveness does involve accountability. It is only when the part that was wrong admits remorsefully to the wrongdoing that forgiveness can be given and will have the potential of saving the relationship. For the benefit of you and your children, because God gives us this advice, is better to forgive than to follow the impulse of the human nature for revenge.

4. Spiritual life. Worship is not something you practice just in church. A spiritual life that is the foundation of a real worship has for the most people the starting 
point in family, where children are taught about God and the principles of the Bible. Abraham was called "the patriarch of altars" due to his custom to build altars for God wherever he established his camp. Every day he gathered together his family-children and servants-and practiced an open worship where people of Canaan assisted. His faith in God was strengthened this way so he could receive from God the promise, "Through your offspring all nations on earth will be blessed" (Gen 22:18).

Even being separated due to some critical conditions, spouses can have a spiritual life together. Some ideas follow:

A. Set a time of the day when both of you meet together at the throne of God in prayer. Decision to pray at the same time, gives a feeling of togetherness. Visualizing the appointment with God at the same hour offers you comfort and increases the sense of intimacy with God and your husband.

B. Decide to study the same book and to pray for the same topics. You can choose a book from family topic or spiritual area. Discover the beauty of reading the same book with that one whom you love.

C. Maintain an open communication despite the distance. Write affectionate letters with a spiritual meaning to each other as often as you can. The author of this dissertation, being under army obligation used to have a colleague who, for one and a half year, sent and received love and encouragement letters to and from his girl friend every single day. During this time he sent and received 540 letters. Technology advancements open easier doors to immediate communication through electronic mail. It is the determination of the individual that makes communication possible at all times. 
5. The ability to cope with conflicts. "The basic pattern in conflictual marriages is one in which neither gives in to the other on major issues." Many families suffer the lack of intimacy and satisfaction in their relationship due to their inability to cope with conflicts. Sooner or later every family is confronted with conflicts. The secret of a successful marriage is not to avoid a conflict, but to face it, to understand each other and to be able to take responsibility for your contribution to the problem, and to find the best solution to it. Instead of point the fingers to each other, it is better to focus on the problem that caused the conflict.

Temporary separation, one could say, limits the amount of conflicts in the family. However, extended separation can become the potential for aggravated conflicts that will develop latently only to explode at a time when nothing much could be done about them. The other risk as that the emotional distance caused by extensive separation, and by the lack of conflicts, could result in a dissolution of the marriage, as spouses become strangers to each other.

\section{Conclusion}

Strengthening families in order to have a better society is priority number one in our social context. Every family should consider that God did not create the institution of family, just to offer to the members of the family to survive. According to God's plan, everybody has the right to offer love and to be loved.

Also, God put in every family enough resources for repair and growth. It is up to everybody to discover these resources and to apply them wisely.

${ }^{1}$ David H. Olson, Treating Relationships (Lake Mills, IA: Graphic Publishing, 1976), 238. 


\section{CHAPTER VII}

\section{A STRATEGY TO STRENGTHENING ROMANIAN SDA FAMILIES: RECOMMENDATIONS AND CONCLUSIONS}

More than ever before, the quality of family life is in decline due to factors that tend to destabilize relationships between spouses, and between parents and children. It would be unfair to analyze these factors only as they affect the family. Actually every aspect of our lives is in someway way influenced by negative factors such as inflation, invasion of immorality by mass-media, violence, and other issues. Stress and unhappiness may be triggered by economic factors. Without a spiritual element present in the life of an individual to provide hope and optimism life seems worthless. A lack of hope and faith could be one explanation for widespread suicidal rates throughout the world.

Every society faces social, economic, and political pressure. As such, each society must adapt its own politics to face new challenges and situations. Old value systems that were once well accepted and uncontested by parents and grandparents may be considered outdated by the present generation. Every generation faces changes in one area of life or another with negative or positive consequences. 
Many foreign analysts wrote about Romanian society after the 1989 Revolution.

Some of their statements were closer to the truth; others presented not the reality but what people from their countries expected to read about Romania.

Identifying factors that negatively affect family life may generate two differing attitudes:

The first attitude may be one of indifference toward the plight of other families. Individuals may be concerned about no one, or may only be concerned about the wellbeing of their immediate families.

The second attitude may be that of a broader perspective: to consider ourselves a part of our society with responsibilities and duties not only in the narrow circle of our family but also a small cog in the big engine of our nation.

To act in accordance with the first attitude represents an act of betrayal. Everyone is responsible, at his or her level, for the happiness or unhappiness of a society. Everyone plays a role in promoting better families, better communities, and a better world. To leave the responsibility of the well-being of a society to its leaders or to its elite would be futile and irresponsible.

In 2006, three years after the survey was taken and focus groups were organized to gather information about families affected by partial migration in Romania, the situation is unchanged. The phenomenon of legal or illegal immigration has increased and more and more Adventist families look for financial support abroad, in Western countries like Spain, France, Italy, Germany, or Great Britain.

According to the latest available information, about 10 percent of the active Romanian population work abroad. From 1990 to the present, about 15 percent of 
Romanian people had a job abroad. Daniel Kozak, Public Relations officer of the International Organization for Workforce Migration, wrote: "The number of Romanian immigrants doubled since 2001. Practically, at present more than 850,000 Romanian people, work in the European Union, the preferred destination countries being Italy, Germany, Spain, and Hungary."1

The crisis created by separation of the spouses is aggravated by a series of factors that add new burdens to the shoulders of the family. It is useful to mention some of these factors in order to have an understanding of the whole picture.

First of all, in the process of making the decision to go abroad for financial purposes, the two spouses have discussions that sometimes degenerate into real arguments. This is the first step toward later accusations if things do not work out according to plan.

Another factor is the status of the emigrant that always places the worker in an inferior position in comparison with a citizen. Besides the social position, we can mention financial disadvantage. It is well-known that an immigrant is paid less than a citizen.

The difference of culture creates an additional stress that is often revealed in feelings of undervaluing and low self-esteem. Due to language differences in the majority of situations, Romanian immigrants continue to work as a Romanian team, so the process of integration into the new culture is postponed a long time. Very few Romanian people know the language of the country where they are going to work when

\footnotetext{
'Daniel Kozak, "Romanian Immigrants," The Last Hour, April 27, 2005, 3.
} 
they leave Romania. This is one reason why they cannot find a well-paying job commensurate with their qualifications.

In order to save money for their families, men (usually it is men who go abroad looking for a job) cannot afford to bring the entire family (wife and children). They try to find a very small room with very basic accommodations so as to pay as little rent as possible. Sometimes the men live four to five people in a regular size room to save money for their families. If the family wants to visit, it is impossible to have intimacy and privacy.

The lack of worker's rights to medical insurance, vacation, and social security make it almost impossible for the worker to visit their families annually. This leads to a cooling of the relationship and reduced communication and contact. At the same time it becomes harder and harder to resist temptations of infidelity. From this point to an adulterous relationship is a short step.

The following material will take into consideration three levels of the Romanian society and will make strategic recommendations for each level.

\section{Recommendations for Individuals}

The poor economic conditions in Romania have triggered an exodus of increasing numbers of native workers seeking employment opportunities abroad. Nobody from the simple man to the president of Romania likes to see Romanian people looking for work in foreign countries in order to help their families survive. Can a simple man have such a strong influence to change society for the better? Yes, by following the next four points. The strategy will be divided in two parts, in order to have a better and clearer understanding of the process: prevention and intervention. The first aspect deals with 
preventive measures having the task to avoid separation caused by the necessity to travel abroad for work in order to provide material and financial help for the family. The second component of our strategy will target people already confronted with temporary separation, its purpose being to strengthen the family unit, by supporting each member and addressing their specific needs.

\section{Recommendations for the Church and Pastor}

According to this study, 75 percent of our respondents expected the church to offer a solution to family crises. The members of the Seventh-day Adventist Church trust their church. They consider it an able organization from God that is involved not only in their spiritual life but also in their material life. The negative aspect of this expectation is that members expect too much from the church.

\section{Prevention}

1. Identifying Church Needs and Resources. Being an organization formed by people for people, the role of the church is not limited to the spiritual area. If all activities of a church take place within the limits of her property, the leaders and the members do not understand the role and mission of the church. Every church, small or large, should identify the needs of her members and as a part of community, the needs of that community which in many cases will coincide. Intentional needs assessment projects should become a regular component in each church's strategic planning.

In assessing the needs in the community/church that could lead to emigration, the following are some suggestions of relevant questions to be addressed through the needs assessment: 
A. Why does this problem [emigration and partial separation] confront people from our church (community)? Where is the root of this problem?

B. What factors contribute to the decision of a family to separate for a limited time in order to work abroad?

C. How spread is this phenomenon in our church (community or country)?

D. What could the church do to prevent couple separation due to temporary emigration for employment purposes?

E. What resources (spiritual, material, human and professional source of help) does the church have access to?

2. Present and discuss the identified economic needs in your immediate community, as well as various work opportunities in the church/local community, to provide accurate information and support as well as alternative solutions for people that intend to emigrate for work.

3. Educate church and community members on all aspects of emigration. In order to start a program in the church regarding the area of emigration, specialists in emigration, family counselors, and people with experience working abroad should be invited to talk. Many wrong decisions are taken due to the lack of information or a superficial understanding of the problem (topic).

4. Establish strategic networks to address the issue. If a church realizes that her financial or human resources are not enough to face the problem, a good idea could be more churches, or even more districts to join together to elaborate a plan, to develop a strategy regarding the prevention of emigration. Due to the urgency of this problem, these meeting could be four times a year. 
5. Establish educational and training programs on financial management and poverty mitigation. The source of a family's poverty may not arise primarily from financial difficulties. A family's source of poverty may stem from financial ignorance, or from poor organization or administrative skills. A specialist in finances should be invited twice a year to present a seminar about how to manage your money. Beside the issue of management, the principle of tithe should be emphasized as a condition of blessing.

6. Identify families with immediate material needs The church doesn't have access to unlimited financial resources to meet the material need of every people. At the same time it is her duty "to look after orphans and widows in their distress" (James 1:27). Every church should have a board whose main objective is to identify families with immediate material needs. In His earthly ministry, Jesus "mingled with men as one who desired their good. He showed His sympathy for them, ministered to their needs, and won their confidence. Then He bade them, "Follow Me."' Once these families are identified, financial or counseling (according to the situation) help will be provided.

7. Provide support through job training programs, career counseling, financial support, etc. In the context of a society confronted with poverty, every church should be a center of information and counseling. Why shouldn't we consider this aspect a part of evangelization, where people from the church and community should be informed regarding the work force demanded, trained, and counseled how to choose the best career, and what job opportunities exists in that area. The church should have a contract with a financial adviser and an official from the work force office in order to provide information and to counsel people interested in starting a new career.

${ }^{1}$ Ellen G. White, Gospel Workers, 363. 
8. Build the networking capacity of the church and the community through collaboration with other agencies. As churches are limited in their expertise and cannot and should not try to resolve all problems associated with poverty or family separation, one important programmatic strategy is to provide referrals to agencies that offer such programs. The Romanian National Agency for Labor Forces established in 1989 through its 42 county offices and 180 local agencies, offers consultancy and orientation in choosing a job according to everybody's education and abilities.

\section{Intervention}

1. Create a support group for people confronted with separation. This group should be chaired by a skilful person whose knowledge and experience can be a source of encouragement and emotional support for all members.

2. Organize training sessions, 4 times a year that will deal with identified needs in the church and the faith community. A family counselor specialized in separation should be invited to speak and to answer to questions..

3. Create a committee chaired by the family life director that will work to identify all the factors that contribute to tension in the family, which lead to family crises culminating in separation and divorce.

4. Develop a mechanism through which to ensure regular contact with both the members of the family that emigrated to work and the members that remained in the local community.

5. The pastor, with the possible help of collaborators, should personally keep in touch with members who left the country and their families in order to bring prosperity to his family. The pastor should be a source of encouragement and spiritual comfort by 
sending pastoral letters or personal messages to those who are far from their families and church. Another aspect of ministry is the family, usually the wife and children, who remain at home. Perhaps these individuals do not need material support, but the crises of aloneness and the sorrows that arise from missing a husband or a father creates a stress factor that the pastor is called by his mission to ameliorate.

6. Seek healing and employ problem-solving strategies to strengthen the family undergoing temporary separation. Rather than preaching against or seeking methods of punishment for those who left their family, the pastor should speak about love and the blessing to "carry each other's burdens, and in this way you will fulfill the law of Christ" (Gal 6:2).

7. Develop a data base with job opportunities abroad, as well as supportive faith communities that can integrate people who are temporarily working in foreign countries. Local churches should be encouraged to develop presentations providing a realistic description of life and work in various Western countries. Usually people who travel abroad lack realistic information about these countries. Unfortunately, the primary source of information about such countries is from movies where life is idealized and wealth is an easy ideal to attain. In a balanced manner, the pastor should present the positive and negative aspects of life in these countries.

Pastors and church members cannot remain judgmental, accusatory, or indifferent. Our calling as the church and as pastors is to follow the advice of the apostle Peter: "Be shepherds of God's flock that is under your care, serving as overseers - not because you must, but because you are willing, as God wants you to be" (1 Pet 5:2). God's flock could be in Romania, Spain, Israel, Germany, or all over the world. 


\section{Recommendations for the Union Conference}

The Family Life Director from the Romanian Union Conference is responsible for assessing, implementing, and coordinating activities that teach and support families in obtaining necessary life skills. That person assesses, implements, and oversees the activities that support the needs of family, thereby enriching the quality of their lives.

In order to become a healthier and more effective church it is recommended that the following steps be implemented at the Union level, towards a comprehensive family wellness strategy:

1. Prepare and promote seminars that could assist pastors in building their ability to minister to people confronted with separation due to financial conditions.

2. Provide information, and talk with Family Life directors from the six conferences about the reality of separation from a financial basis as a destabilizing factor of the family.

3. Supervise and participate in implementing seminars and sermons on family wellness.

Because the Family Life director from the Conference has about the same responsibilities as Family Life Director from the Union, their duties in relationship with the pastors of districts are about the same as those noted above. What is also recommended is to take time to gather pastors from all districts and to create a plan to implement the ideas that are generated. 


\section{Services Outside of the Church}

Besides the factors presented above, there are some public institutions where everybody has access to get financial or counseling assistance. Below are listed some of the public services available.

The endowed establishment (foundation) "The Relief" is a non-governmental organization whose goal is to help people of different religions, ethnic groups, ages, sick people and families with financial problems. The foundation collaborates with other governmental or non-governmental institutions, such as: The Office for Child Protection and Social Services from the City Hall. The object of activity of this office is the achievement of actions, in order to meet individual, familial, or group social needs, to prevent and surpass difficult situations. Another institution is the Romanian Foundation Hope" provides help for: abusive situations in the family, families in the divorce process, physical or neurotic exhaustion of parents and others. The foundation collaborates with other governmental institutions like the State Secretariat for Disabilities People in Bucuresti which was established in 1990 to provide social assistance and counseling to disabled people confronted with poverty and lack of employment. The foundation also deals with Lebenshilfe Salzburg (Austria), founded in 1967. Material support is given to all members in strained circumstances and builds strategies for solving crisis situations. This support comes from donations and sponsors. Communitarian Help Foundation has establishments in different areas where people without material and financial possibilities have the opportunity to have food. The needy spend their time working on different . 
projects at the foundation in order to sustain it financially. This establishment is sponsored by the local City Halls with Phare ${ }^{1}$ funds.

Every City Hall has a Public Services of Social Assistance office where people in a financial crisis can apply for material help for a limited time.

The Office of Prevention and Alleviation of Poverty provides emergency help and social help on the basis of Law 416/2001. It also gives meals at Social Canteens, and helps pay for heating bills during the cold season on the basis of Law 208/1997.

The government also provides grant-in-aid for single-parent families, and complementary financial help for low-income families. The government provides money from its budget that is distributed by the Work Department, Social Solidarity, and to the Family and at the local level, by the County Office for Family, Dialogue, and Solidarity.

The entire Romanian society-the church included-is confronted with an economic crisis that has a strong impact upon the family as well as each individual. Belonging to the same family —-the family of God-every human being Adventist, Christian or non-Christian must have a place in our concern about their spiritual, material, moral, and relational being. The limited resources of society and the church, especially finances, are the most difficult barriers for helping people confronted with poverty that led to family separation for economical reasons. Even though this aspect is a

${ }^{1}$ The Phare program "Poland Hungary Aid for the Reconstruction of the Economy," is one of the three pre-accession instruments financed by the European Union to assist the applicant countries of Central and Eastern Europe in their preparations for joining the European Union. Originally created in 1989 to assist Poland and Hungary, the Phare Program currently covers ten countries (the eight new Member States): the Czech Republic, Estonia, Hungary, Latvia, Lithuania, Poland, Slovakia, and Slovenia, as well as Bulgaria and Romania. http://europa.eu.int/comm/enlargement/pas/phare (March $23,2004)$. 
cruel reality, the church and society could do more for such families, creating an atmosphere of warm relationships, encouragement, promoting the moral and ethical values of the family, and practicing a kind of religion recommended by Scripture:

"Religion that God our Father accepts as pure and faultless is this: to look after orphans and widows in their distress and to keep oneself from being polluted by the world" (Ja $1: 27)$.

The mission of the church, which includes pastors, members, and institutions, is to preach the gospel in a practical way, meeting the needs of people and bringing them to a safe environment. "As the members of a true family care for one another, ministering to the sick, supporting the weak, teaching the ignorant, training the inexperienced, so is "the household of faith" to care for its needy and helpless ones. Upon no consideration are these to be passed by."1

${ }^{1}$ Ellen White, The Ministry of Healing, 201. 
APPENDIX A

\section{Family Separation in the SDA Romanian Church Survey}

Demographics:

Age:
a. $<20$
b. $21-30$
c. $31-40$
d. $41-50$
e. $50>$

Sex:

M

F

Civil Status:
a. Married
b. Single
c. Divorced
d. Widow/widower

Years of marriage:
a. $<5$
b. $6-10$
c. 11-15
d. $16>$

Number of children:
a. 0
b. 1
c. 2
d. 3 
Religion:
a. SDA
b. Orthodox
c. Catholic
d. Neo-protestant

Years in the SDA church:
a. $0-3$
b. $4-10$
c. $11-20$
d. $21>$

Profession:
a. Stay-at-home
b. Pensioner
c. Student
d. Businessman
e. Professor
f. Doctor
g. Worker
h. Nurse
i. Pastor
j. Economist
k. Accountant
1. Dental technician

Ethnicity
a. Romanian
b. Magyar
c. German
d. Romany 
Years of studies:
a. $1-4$
b. 8
c. 12
d. College
e. Graduate

\section{A. Reasons for Separation}

1. What are the reasons that contribute to the separation of the family? Check all that apply.
a) poverty
b) desire to be rich
c) conflicts/arguments in the family
d) poor communication
e) religious differences
f) infidelity
g) desire for adventure
h) other

2. Keeping in mind the hard economical situation in Romania, do you think that the temporary separation is the key for resolving some relational or economical problems?
a) Never
b) Sometimes
c) Always
d) I do not know 
3. Do you consider that being part of the church is a solution for family conflicts?
a) Never
b) Sometimes
c) Always
d) I do not know

4. Is the SDA family in Romania confronted with economical problems?
a) Yes
b) No
c) I do not know

5. In case of crisis, would you agree with the separation of the spouses for a limited period of time? Please circle the answer that best describes your opinion.

Yes, for:

$$
\text { No }
$$
a) 1-6 months
b) 1 year
c) 2 years
d) More than 2 years

6. If you were confronted with an economic problem (lay off, too little money for your expenses, etc) would you consider temporary separation a solution?

Yes, only for:
a) 0-6 months
b) 1 year
c) 2 years
d) more than 2 years 
7. In your opinion, who makes the final decision for separation?
a) husband
b) wife
c) extended family
d) children
e) parents and children
f) both spouses

8. What would the advantages be of a temporary separation for the economic reasons?
a) personal accomplishments
b) financial possibilities for the family
c) chance to support the children financially
d) material advantages impossible to achieve at home
e) other
f). I do not know

9. What would the disadvantages be of a temporary separation for economic reasons?
a) weakening the relationship between spouses
b) infidelity
c) weakening relationship with children
d) Other
e) I do not know

\section{B. The Involvement of the Church}

10. What is the church's attitude towards separation?
a) Acceptance for reason of adultery
b) Acceptance for serious conflict situations
- Physical violence 
- Verbal violence

- emotional violence

- sexual abuse

- violence

- alcoholism

c) Rejection of the idea of separation

d) Indifference ("it is their business not the church's")

e) Indifference ("we are sorry, but we have more important priorities")

f) Other

g) I do not know

11. What is the pastor's attitude towards the separation for economic reasons?
a) Encourages temporary separation
b) Non involvement
c) Accepts temporary separation
d) Accepts only when other solutions failed
e) Offers conciliation through:
- Personal visiting
- Prayer
- Personal contact by mail
f) Other
g) I do not know

12. Did you feel the church's support during separation?
a) Does not apply
b) Never
c) Seldom
d) Sometimes
e) Frequent 
f) Always

13. Who did offer you support during the separation time?
a) Friends from the church
b) Members of the church
c) Pastor and his wife
d) My family
e) Friends outside of the church
f) Others

14. What type of support was offered to you?
a) Material (food, clothes, money)
b) Emotional (invitation for a dinner, a shoulder to cry on, etc)
c) Spiritual (study; prayer, biblical discussions)

15. During the separation time, what was the reaction of the church's members?
a) Supportive
b) Indifferent
c) Criticism
d) Defiance
e) Envy
f) Espionage
g) Other

\section{The involvement of the Community}

16. During the separation time, what was the reaction of your neighbors?
a) Supportive
b) Indifferent
c) Criticism 

d) Defiance
e) Envy
f) Espionage
g) Other

17. During the separation time, what was the reaction of your fellow workers?
a) Supportive
b) Indifferent
c) Criticism
d) Defiance
e) Envy
f) Espionage
g) Other

18. During the separation time, what was the reaction of your friends?
a) Supportive
b) Indifferent
c) Criticism
d) Defiance
e) Envy
f) Espionage
g) Other

19. During the separation time what was the reaction of your relatives?
a) Supportive
b) Indifferent
c) Criticism
d) Defiance
e) Envy
f) Espionage 


\section{g) Others}

20. Beside the church, did you appeal to other services/organizations/ resources for moral, emotional and relational support?
a) Yes
b) No
c) Sometimes

21. If "Yes", please check the ones you appealed to:
a) Humanitarian organizations
b) Special organization from the town hall
c) Other
d) I do not know

22. In case of separation, would you appeal to other services/organizations/ resources for moral, emotional and relational support?
a) Yes
b) No
c) I do not know

23. If "Yes", please check the ones you would appeal to:
a) Church
b) Humanitarian organizations
c) Special organization from the town hall
d) Other
e) I do not know

24. Did somebody support you emotionally and morally during the time of separation? Who?
a) Nobody
b) Friends 

c) Relatives
d) My husband/wife's relatives
e) Children
f) Neighbors
g) Members of the church
h) Members of the church board
i) Pastor
j) Other

25. Would you consider paying a visit to someone who is confronted with the separation problem?
a) Yes
b) No
c) I did not think about it

26. What did you do for those who are confronted with separation problem to support them emotionally/spiritually?
a) visits
b) prayer
c) dinner invitation
d) invitation to the church
e) support-group
f) other

\section{Recommendations, solutions}

27. What do you think the church could do for the families that are confronted with the separation problem?
a) Establish a support group in the church for such families
b) Disciplinary measures for those who take the decision of separation 
c) Looking for solutions so that the family can stay together

d) I do not know

28. What do you think the pastor could do for the families that are confronted with the separation problem?

a) To preach sermons presenting strong reasons against the idea of separation

b) To decide what disciplinary measures can be used against the family confronted with the problem of separation

c) To discuss with the board of the church what strategy would be the best in order to offer support to such families

d) To keep in touch with those who are abroad

e) Others

29. After the experience of separation for economic reasons, what are the conclusions of this experience?

a) It was worth the effort

b) I would not repeat this experience

c) I would not give an advice to anybody to accept this solution

d) The loss on the relational plan was more than the material profit

e) The separation experience brought a benefit of freshness and love to our family

f) I am ready to share to others the positive aspects of this experience 


\section{APPENDIX B}

Topics for Focus Group

1. Ideal and reality in the Christian family

2. Current problems of the Christian family and methods of confronting these problems

3. Separation as a solution or an aggravating factor of the family's problems

4. The role of the church (theory and reality) in assisting the family confronted with problems

5. The role of the pastor-what he should do vs. what he does

6. Potential solutions in the church and community 
APPENDIX C

\section{ROMANIAN ADVENTISTS' EMIGRATION FOR WORK-AN APPEAL FOR MATURE DECISIONS. OPPORTUNITIES FOR PASTORAL MINISTRY}

\section{Work Emigration Statement}

Voted at 2001 Year-end Committee of Romanian Union

November 22, 2001-Bucharest

In recent years, a large number of our church members have spent a longer or shorter time, working outside the country. Only a few of them have obtained work legally with the appropriate permission and residence status, while several thousand are continuing to work in temporary and provisional situations. Interest in these church members became an important concern for both the new churches they are attending, and the Romanian Adventist Church.

The implications are complex and hard to evaluate. Often the churches they are attending are experiencing considerable development. In the meantime, there are some negative effects, such as moral and spiritual personal crises, that have negative, irreversible, long-term consequences in the family life area. The local churches they left in Romania are deeply affected by losing a high percentage its most capable members.

We can't fully understand the trends and perspectives of the work emigration phenomenon, but the possible relaxation of the visa requirement may cause an upsurge of emigration. We recognize that each church member has the freedom to decide where to live, where to work, and which local church to attend, but they must be sure they are 
conforming with civil laws and ecclesiastical regulations. We are ready to help those facing major decisions, so we encourage local pastors and leaders to support these church members respectfully and understandingly, and guide them to mature and responsible decisions.

Those looking for work possibilities outside the country are urged to evaluate the real opportunities for work and development which may be available in Romania, before assuming that it is essential to work outside Romania. They must have accurate information regarding the social, economic and spiritual context of the new location, in order to avoid wrong and risky decisions. The decision process must involve all family members. Arrangements that result in extended separation from family members have long-term negative effects.

Though the material area of our life can't be ignored, the moral and spiritual dimensions must have priority in the process of making major decisions. We must meet present needs, but not at the expense of the future and eternity.

We urge our pastors and local church leaders to develop a spiritual healthy environment, and to use a positive approach to this hot topic. They should identify and use sound biblical principles, and examples from similar situations, to inform the members about appropriate courses of action. We are working through our church educational system and other channels to support our church members who are not leaving the country so that they can enjoy both their spiritual experience and find work opportunities to provide for the welfare of their family members. At the same time we will work in cooperation with leaders of the churches from other countries to provide as 
much support as possible to our church members who are working temporarily outside of Romania.

By God's grace and by corporate effort, we believe that we will find biblical and practical solutions to this complex situation, so that our church will be more capable of demonstrating Gospel values, by which the people may be enriched and made ready for eternal salvation, at the soon coming of Jesus. 


\section{BIBLIOGRAPHY}

Adams, Jay E. Christian Living in the Home. Philipsburg, NJ: Presbyterian and Reformed Publishing Company, 1972.

Andrei, Petre. Sociological Works. Bucharest, Romania: Academy Publishing House, 1997.

Anderson, Douglas A. New Approaches to Family Pastoral Care. Philadelphia: Fortress Press, 1980.

Arvatu, Cristina. Family in Transition. Bucuresti, Romania: The Day, Bucuresti, March 20, 2003.

Bedford, Victoria H., and Blieszner Rosemary. "Older Adults and Their Families." In Handbook of Family Diversity, eds. David H. Demo, Katherine R. Allen, Mark A. Fine, 218. New York: Oxford University Press, 2000.

Boyd, Monica. "Family and Personal Networks in International Migration: Recent Developments and New Agendas." International Migration Review 23, no. 3, Special Silver Anniversary Issue: International Migration an Assessment for the 90's (Autumn, 1989): 638-670.

Campbell, Edward F., Jr. Ruth. New York: The Anchor Bible, 1975.

Cioran, Emil. Romania's Transfiguration. Bucharest, Romania: Humanitas Publishing House, 1990.

Collins, Gary. Christian Counseling: A Comprehensive Guide. Waco TX: Word Books, 1980.

Kramer, Sue W. Domestic Violence-The Circle Called Love. Philadelphia, PA: Xlibris Corporation, 2000.

Council of Europe Committee of Ministers. Action Against Trafficking in Human Beings for the Purpose of Sexual Exploitation. Recommendation No. R (2000), Bern, Switzerland. 
Dattilio, Frank M. Case Studies in Couple and Family Therapy. New York, NY: Guilford Press, 1998.

Diminescu, Dana. Visible, But Not Very Numerous. The Romanian Migratory Circouites. Paris, France: Editions of the House of the Sciences of the Man, 2003.

Dobson, James. Complete Marriage and Family. Wheaton, IL: Tyndale House Publishers, Inc., 2000.

Elias, Marilyn. "Psychologists Now Know What Makes People Happy." US Today December 10, 2002. http://www.biopsychiatry.com/happiness/ (June 29, 2006).

Edwards, John N., ed. The Family \& Change. New York, NY: Alfred A Knopf, 1969.

Mogey, J. M. A Century of Declining Parental Authority. New York, NY: Knopf, 1969.

Ezel, Margaret J. M. The Patriarch's Wife-Literary Evidence and the History of the Family. Chapel Hill, NC and London: The University of North Carolina Press, 1987.

Family Public Opinion. "Strengthening Families a Priority for Americans." The Christian Century 117 (September 2000): 948.

Family Relations 42, no. 1 (January 1993): 38-45.

Friedman, Edwin H. Generation to Generation. New York: The Guilford Press, 1985.

General Conference of Seventh-day Adventist. Seventh-day Adventist Church Manual. Hagerstown, MD: Review and Herald, 1995.

Gerson, Kathleen. "How Women Choose Between Employment and Family: A Development Perspective." In Families and Work, ed. Naomi Gertsel and Gross Harriet Engel, 276. Philadelphia, PA: Temple University Press, 1987.

Gheorghiu, Mihai Ursu. Who Shot Ceausescu? Bacau, Romania: Plumb Publishing House, 1994.

Glasser, Paul, and Lois Glasser, Families in Crisis. Edited by Richard B. Stuart. New York: Harper \& Row Publishers, 1970.

Guizot, Francois. The History of Civilization in Europe. West Midlands, England: Arden Library, 1983.

Gusti, Dimitrie. Opere. Vol. 1. Bucharest, Romania: Academy Publishing House, 1958.

Hales, Dianne. The Family. New York: Chelsea House Publisher, 1988. 
Holman Bible Dictionary. Edited by Trent C. Butler. Nashville, TN: Holman Bible Publisher, 1991.

Holt, John Marshal. The Patriarchs of Israel. Nashville, TN: Vanderbilt University Press, 1964.

HotNews, February 23, 2006. http://english.hotnews.ro/ Romanians- abroad-sent-back4.3-billion-euro-in-2005-articol_42143.htm (July 5, 2006).

Hunt, Ignatius. The World of the Patriarchs. Enhlewood Cliffs, NJ: Prentice-Hall, Inc., 1967.

lliut, Petru. Knowledge and Assistance. Cluj-Napoca, Romania: Argonaut Publishing House, 1995.

Imbornoni, Ann Marie. Women's Rights Movement in the U.S. http://www.infoplease .com/spot/womenstimeline1.html\#WHM-1800 (July 6, 2006).

Johnson, Caitlin. Strengthening Families Ties. http://www.connectforkids.org/node/375 (July 6, 2006).

Kaplan, Lisa, and Judith L. Girard. Strengthening High-Risk Families. New York, NY: Macmillian, Inc., 1994.

Kates, Judith A., and Gail Twersky Reimer, eds. Reading Ruth. New York: Ballantine Books, 1994.

Kinner, Craig S. Virtue Illustrated by the Christian Family. London, England: InterVarsity Press, 1994.

Kozac, Daniel. "Romanian Immigrants." The Last Hour, April 27, 2005. http://www.ultima-ora.ro/ (June 30, 2006).

Lewis, Steven. The ABC's of Real Family Values. Harmonswordsworth, Middlesex, England: Penguin Books, Ltd., 1998.

Lewis, Suzan. "An International Perspective on Work-Family Issues." In Integrating Work and Family, eds. Saroj Parasuraman and Jeffery H. Greenhouse, xii. Westport, CT: Quorum Books, 1997.

Linzer, Norman. The Jewish Family: Authority and Tradition in Modern Perspectives. New York: Human Science Press, 1984.

McDonald, Peter, and Rebecca Kippen. "Labor Supply Prospects in 16 Developed Countries, 2000-2050." Population and Development Review 27, no. 1 (2001). 
Miroiu, Mihaela. The Anonymous Half. Bucharest, Romania: Academy Publishing House, 1995.

Mitrofan, Iolanda. Conjugal Couple — Harmony and Disharmony. Bucharest, Romania: Academy Publishing House, 1998.

Neagu, Aurel. Illegal Migration at Romanian Borders. Paper presented at the Migrationsfragen und Minderheitenrechte in Europe, International Symposium Goethe-Institute, Bucharest, Romania, 29-30 März 2004.

Newman, Jay. Biblical Religion and Family Values: A Problem in the Philosophy of Culture. Westport, CT: Praeger/Greenwood Publishing Group, 1948.

Odobleja, Stefan. The Consonantal Psychology. Bucharest, Romania: Scientific and Encyclopedic Publishing House, 1982.

Official Bulletin. Family Code. Republished in Official Bulletin \# 108, Bucharest, Romania, August 1, 1974.

Olson, David H. Families-What Makse Them Work. Beverly Hills, CA: Sage Publication 1983. . Treating Relationships. Lake Mills, IA: Graphic Publishing Co., 1976.

Orhant, Melanie. "Romanian Women Work as Prostitutes Abroad." The Associated Press, October 25, 2000.

Orthner, Dennis K. "Strengthening Today's Families." Parks \& Recreation 33 no. 3 (March 1998): 87.

Pierce, Gregory R., ed. Handbook of Social Support and the Family. New York: Plenum Press, 1996.

Queen, Stuart A., Robert W. Habenstein, and John B. Adams. The Family in Various Culturse. Chicago, IL: J. B. Lippincott Company, 1961.

Richardson, Willie. Reclaiming the Urban Family-How to Mobilize the Church As a Family Training Center. Grand Rapids, MI: Zondervan Publishing House, 1996.

Romania-Emigration: Problem or Solution? http://www.country-data.com/cgi-bin/query/ r-11151.html (July 5, 2006).

Ryan, John A. Family. http://www.newadvent.org/cathen/ 05782a.htm (July 7, 2006).

Scarpitti, Frank R., Margaret L. Andersen, Laura L. O'Tolle. Social Problems. New York: Addison Wesley Longman, Inc., 1996. 
Scott, Franklin D. Emigration and Immigration. Baltimore, MD: Waverly Press, Inc., 1966.

Sell, Charles M. Family Ministry. Grand Rapids, MI: Zondervan Publishing House, 1995.

Smart, Mollie S. and Laura Stevens Smart. Families-Developing Relationships. New York, NY: Macmillan Publishing Co., 1976.

Smedes, Lewis B. Caring \& Commitment. San Francisco: Harper \& Row Publishers, 1988.

Forgive \& Forget. San Francisco: Harper Collins Publisher, 1996.

Swindoll, Charles R. Growing Wise in Family Life. Portland, OR: Multnomah Press, 1988.

Taft, Donald R. International Migration-The Immigrant in the Modern World. New York, NY: The Ronald Press Company, 1955.

Tesliuc, Cornelia M., Lucian Pop, and Emil D. Tesliuc. Poverty and Social Protection System. Bucharest, Romania: Polirom Publishing House, 2001.

Totok, William. Romania of the 70's: A Naked Truth. Stuttgart-Munich, Germany: German Publishing House, 2001.

Toro-Morn, Maura I., ed. Migration and Immigration-A Global View. Westport, CT: Greenwood Press, 2004.

"Romanian Money from Abroad Helps the National Economy." The Truth, June 29, 2006.

Tucker, Bill. A Need for Healthy Families. Redlands, CA: The Quiet Hour, 1994.

U.S. Census Bureau. Martial Status and Living Arrangements, March 1998. http://www.gendercenter.org/mdr.htm, (June 30, 2006).

Voinea, Maria. Family and Its Historic Evolution. Bucharest, Romania: Academy Publishing House, 1978.

. Family Sociology. Bucharest, Romania: University Press, 1993.

Voydanoff, Patricia. Work and Family Life. Newbury Park, CA: Sage Publications, 1987.

Walsh, Froma. Strengthening Family Resilience. New York: The Guilfor Press, 1998. 
Warren, Josiah. Practical Details. New York: Riverside Press, 1852.

White, Arthur L. Ellen G. White: A Brief Biography. Silver Spring, MD: Ellen G. White Estate, 2000.

White, Ellen G. Advent Review and Sabbath Herald, September 8, 1904.

. The Adventist Home. Washington, DC: Review and Herald Publishing Association, 1980.

Child Guidance. Washington, DC: Review and Herald Publishing Association, 1982.

Conflict and Courage. Washington, DC: Review and Herald Publishing Association, 1970.

. The Daughters of God. Hagerstown, MD: Review and Herald Publishing Association, 1998.

The Faith I Live By. Hagerstown, MD: Review and Herald Publishing Association, 2000.

. God's Amazing Grace. Washington, DC: Review and Herald Publishing Association 1973.

. Manuscript Release v 18. Ellen G. White Research Center. Andrews University, Berrien Springs, MI.

Mind, Character and Personality. Nashville, TN: Southern Publishing Association, 1977.

. Ministry of Healing. Mountain View, CA: Pacific Press Publishing Association, 1909.

. Ministry of Healing. Boise, ID: Pacific Press Publishing Association, 1988. 1989.

Patriarchs and Prophets. Boise, ID: Pacific Press Publishing Association, . The Signs of the Times, November 11, 1903.

. Testimonies for the Church. Vol. 1. Mountain View, CA: Pacific Press Publishing Association, 1948.

Testimonies for the Church. Vol. 6. Mountain View, CA: Pacific Press Publishing Association, 1928. 
Willcox, Walter, ed. International Migration. New York, NY: Arno Press and The New York Times, 1970.

Wright, Norman. Building Positive Parent-Teen Relationships. Irvine, CA: Harvest House Publishers, 1977. 


\section{VITA}

Personal and Family Data:

Name:

Date of Birth:

Place of Birth:

Wife:

Marriage:

Children:

Mihail Baciu

June 24, 1953

Bacau, Romania

Viorica

July 16,1978

Ada Mihaela, 24

Eva Cezara, 22

Education Experience:

2002-2006

Doctor of Ministry-Andrews University, USA

1999-2001

Master of Divinity-Andrews University, USA

1995-1998

B.A. in Theology-Cluj-Napoca, Romania

$1976-1980$

Theological Seminary-Bucharest, Romania

$1966-1970$

High School-Bacau, Romania

$1959-1966$

Elementary School-Bacau, Romania

Professional Experience:

2002-present

1997-1998

$1995-1997$

1993-1995

1990-1993

$1985-1990$

1980-1985
Pastor-Superior District Seventh-day Adventist, Wisconsin Conference, USA

Pastor-Seventh-day Adventist Church, Focsani, Romania

Secretary-Moldavia Conference, Romanian Union

Pastor-Seventh-day Adventist Church, Bacau,

Romania

Youth Director-Moldavia Conference, Romanian Union

Pastor-Vatra Dornei District, Romania

Associate Pastor-Grivita District, Romania 